\title{
Interpretation of the
}

Composition and a

Classification of

the Chlorites

GEOLOGICAL SURVEY PROFESSIONAL PAPER 414-A 


\section{Interpretation of the}

Composition and a

Classification of

the Chlorites

By MARGARET D. FOSTER

SHORTER CONTRIBUTIONS TO GENERAL GEOLOGY

GEOLOGICAL SURVEY PROFESSIONAL PAPER 414-A

A study of the compositional relations

of chlorites and a classification based

on the two principal types of ionic

replacement found in them

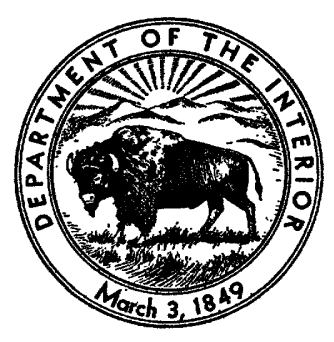

UNITED STATES GOVERNMENT PRINTING OFFICE, WASHINGTON : 1962 


\section{UNITED STATES DEPARTMENT OF THE INTERIOR \\ STEWART L. UDALL, Secretary \\ GEOLOGICAL SURVEY \\ Thomas B. Nolan, Director}

For sale by the Superintendent of Documents, U.S. Government Printing Office

Washington 25, D.C. 


\section{CONTENTS}

Abstract

Introduction

Selection of analyses

Structural formulas

Calculation of formulas

Theoretical $\mathrm{O}(\mathrm{OH})$ versus determined $\mathrm{H}_{2} \mathrm{O}(+)$

Relation between $\mathrm{Fe}^{+3}$ and $\mathrm{O}$

Relation between tetrahedral and octahedral $\mathrm{Al}$

Relation between $\mathrm{Si}$ and $\mathrm{Fe}^{+2}: \mathrm{R}^{+2}$

Magnesium replacement series. \begin{tabular}{r|lr} 
Page & Page \\
$\mathrm{A}-1$ & $\mathrm{Si}$ and $\mathrm{R}^{+2}$ replacement of $\mathrm{R}^{+3}$ & $\mathrm{~A}-13$ \\
1 & $\mathrm{Fe}^{+2}$ replacement of $\mathrm{Al}$ and $\mathrm{R}^{+2}$ & 14 \\
2 & $\mathrm{Status}^{+2} \mathrm{Fe}_{2} \mathrm{O}_{3}$ in chlorites & 15 \\
2 & Classification of chlorites & 17 \\
2 & Some previous classifications & 17 \\
3 & Classification based on ionic replacements & 22 \\
5 & Allocation of octahedral cations & 24 \\
7 & Summary and conclusions & 25
\end{tabular}

\section{ILLUSTRATIONS}

FIGURE 1. Relation between $\mathrm{Fe}^{+8}$ and $\mathrm{O}$ in chlorites

2. Relation between tetrahedral $\mathrm{Al}$ and octahedral $\mathrm{Al}$

3. Relation between octahedral occupancy and octahedral $R^{+3}$ (and $R^{+4}$ ) cations in excess of tetrahedral $R^{+8}$ cations

4. Relation between formula positions occupied by $\mathrm{Si}$ and the $\mathrm{Fe}^{+2}: \mathrm{R}^{+2}$ ratio

5. Diagrams of octahedral groups of average formulas showing transition in character from highly magnesian to highly ferroan in the Si range 2.50-2.70

6. Diagrams of average formulas showing change in composition of chlorites having $\mathrm{Fe}^{+2}: \mathrm{R}^{+2}$ ratio less than 0.10 with increase in $\mathrm{Si}$ content.

7. Diagram showing relation between $\mathrm{Fe}^{+2} \cdot \mathrm{R}^{+2}$ ratio and $\mathrm{Fe} \mathrm{O}_{3}$ in chlorites

8. Classification of chlorites studied according to Hey (1954)

9. Classification of chlorites based on the two principal types of ionic replacement

\section{TABLES}

TABLE 1. Example of the calculation of structural formula of chlorites

2. Analyses and data for writing formulas of chlorites used in study
Page

A-6

8

10

11

12

14

16

18

19 


$$
-
$$




\title{
INTERPRETATION OF THE COMPOSITION AND A CLASSIFICATION OF THE CHLORITES
}

\author{
By Margaret D. Foster
}

\begin{abstract}
Structural formulas calculated for more than 150 selected published analyses of chlorites show that octahedral $\mathrm{Al}$ is not often closely equivalent to tetrahedral $\mathrm{Al}$, being higher in about one-fourth of the formulas, and lower in about one-half. If lower, some other octahedral trivalent cation, usually $\mathrm{Fe}^{+3}$, is present and proxies for $\mathrm{Al}$ in providing sufficient octahedral positive charge to balance the tetrahedral negative charge. Octahedral occupancy is close to 6.00 only if the sum of the octahedral trivalent cations is approximately equal to tetrahedral Al. If it is greater, as is most usual, octahedral occupancy is less than 6.00 formula positions by an amount equal to about one-half the excess of octahedral trivalent cations over tetrahedral $\mathrm{Al}$, indicating that the excess octahedral trivalent cations replace bivalent cations in the ratio of 2:3.

No correlation was found between $\mathrm{Fe}_{2} \mathrm{O}_{3}$ and $\mathrm{O}$ content in excess of 10.0 ions per half cell. This, and the facts that in many chlorites some or all of the $\mathrm{Fe}^{+3}$ present is necessary for structural balance, and that many chlorites are formed as alteration products of other minerals that may contain $\mathrm{Fe}^{+3}$ ions, suggest that $\mathrm{Fe}_{2} \mathrm{O}_{3}$ is a normal constituent of many chlorites, particularly of ferroan chlorites, and that its presence should not arbitrarily be taken as evidence of secondary oxidation.
\end{abstract}

Two series of ionic replacements characterize the chlorites, replacement of tetrahedral and octahedral $\mathrm{Al}$ by $\mathrm{Si}$ and $\mathrm{Mg}$, and replacement of $\mathrm{Mg}$ by $\mathrm{Fe}^{+2}$. Replacement of one $\mathrm{Al}(\mathrm{IV})$ and one $\mathrm{Al}(\mathrm{VI})$ by one $\mathrm{Si}$ and one $\mathrm{Mg}$ involves both the tetrahedral and octahedral layers and causes changes in the layer charges, but replacement of one $\mathrm{Mg}$ by one $\mathrm{Fe}^{+2}$ involves only the octahedral layers and does not change the layer charges. Replacement of $\mathrm{Al}(\mathrm{IV})$ and $\mathrm{Al}(\mathrm{VI})$ by $\mathrm{Si}$ and $\mathrm{Mg}$ amounts to about one formula position in the group of chlorites studied, from about $\left(\mathrm{Al}_{1.80} \mathrm{Mg}_{4.40}\right)\left(\mathrm{Si}_{2.40} \mathrm{Al}_{1.80}\right) \mathrm{O}_{10}(\mathrm{OH})_{8}$ to about $\left(\mathrm{Al}_{.80}\right.$ $\left.\mathrm{Mg}_{5.40}\right)\left(\mathrm{Si}_{3.40} \mathrm{Al}_{.60}\right) \mathrm{O}_{10}(\mathrm{OH})_{8}$, and is represented most fully by the highly magnesian chlorites. The replacement of $\mathrm{Mg}$ by $\mathrm{Fe}^{+2}$ is demonstrated most continuously and completely by chlorites in the lower part of the Si range, Si 2.50-2.75, where the full range, from wholly magnesian to wholly ferroan is represented.

A classification scheme for the chlorites, based on these two replacement series, divides the chlorites into nine species which are strictly defined on the basis of $\mathrm{Si}$ content and ratio of $\mathrm{Fe}^{+2}$ to $\mathrm{R}^{+2}$.

After consideration of various ways of distributing the octahedral cations between the two octahedral layers, it is concluded that an equal distribution of the various kinds of octahedral ions present is most likely, but that the way the ions are distributed may not necessarily be the same in all chlorites.

\section{INTRODUCTION}

The chlorites are hydrous silicates of aluminum, and magnesium and (or) ferrous iron; many contain ferric iron, and some contain chromium or manganese. The chlorites vary greatly in chemical composition, and this great variation led in the past to the introduction of many varietal names, some without adequate definition. Some names have been used to indicate a certain range in composition, but there is considerable overlapping, and the limits of ranges of composition have been fixed arbitrarily and variously by different investigators. Before X-ray methods of study were available, various attempts were made to classify the chlorites. In most of these classifications, as, for example, in that of Tschermak (1891), Orcel (1926), Winchell (1936), and Hallimond (1939), the composition of chlorites was interpreted as made up of varying proportions of certain end members. Since Mauguin's pioneering work $(1928,1930)$ in elucidating the chlorite structure, X-ray studies have shown that all members of the chlorite family have the same type of structure and that the compositional differences of chlorites can be attributed to isomorphous replacement of cations within the structural framework, as in the micas. Such investigations have also shown that several species formerly included with the group, such as amesite (Gruner, 1944) and cronstedtite (Hendricks, 1939) do not have the chlorite structure. Faust (1955) provided the X-ray proof that removes griffithite from the chlorite group.

Pauling (1930) showed that the composition of the chlorites requires that in one unit Iength along $c$ there be two Iayers of Si-O tetrahedra and two octahedral layers, similar to brucite, $\mathrm{Mg}(\mathrm{OH})_{2}$, with one of the octahedral Iayers bound between the two tetrahedral Iayers, forming a micalike unit. 
With micalike units and brucitelike layers alternating, there is thus also alternation of tetrahedral and octahedral layers. The structure leads to the general formula $\mathrm{X}_{\mathrm{m}} \mathrm{Y}_{4} \mathrm{O}_{10}(\mathrm{OH})_{8}$, with the tetrahedral layers having the formula $\mathrm{X}_{\mathrm{m} / 2} \mathrm{Y}_{4} \mathrm{O}_{10}(\mathrm{OH})_{2}$, and the octahedral layers having the formula $\mathrm{X}_{\mathrm{m} / 2}(\mathrm{OH})_{6}$. In these formulas $\mathrm{X}$ and $\mathrm{Y}$ represent octahedral and tetrahedral cations, respectively, and $m$ is usually 6 , or somewhat less, but not more. If $\mathrm{Y}$ were made up entirely of $4 \mathrm{Si}^{+4}$ ions the tetrahedral layers would be neutral, as 16 of the 28 negative charges carried by $\mathrm{O}_{10}(\mathrm{OH})_{8}$ are associated with the tetrahedral layers; but in all chlorites there are some $R^{+3}$ ions, usually $\mathrm{Al}^{+3}$, proxying for $\mathrm{Si}^{+4}$, and the tetrahedral layers have a resultant negative charge equivalent to the amount of $\mathrm{Al}^{+3}$ proxying for $\mathrm{Si}^{+4}$. Similarly, if $\mathrm{X}$ were made up entirely of $6 \mathrm{R}^{+2}$ ions, the octahedral layers would be neutral, as the 12 positive charges carried by $6 \mathrm{R}^{+2}$ ions would just neutralize the 12 negative charges associated with the octahedral layers. However, for structural balance the octahedral layers must carry a positive charge equivalent to the negative charge on the tetrahedral layers, and consequently, the octahedral layers must contain $R^{+3}$ cations sufficient to balance the negative tetrahedral charge.

The presence of layers not held together by anioncation contacts explains the excellent cleavage on (001). The cleavage lamellæ, though tough, are not so elastic as those in the micas, as the effect of the $\mathrm{K}$ ions in keying adjacent layers is absent in the chlorites. On the other hand, the chlorites, because of the presence of alternately negatively and positively charged layers, are not as soft as kaolinite and talc, whose layers are not charged.

In the present study, which is based on formulas calculated from more than 150 published analyses, attention is given to the principal types of ionic replacement in the chlorites, the effect of $R^{+3}$ proxying for $\mathrm{R}^{+2}$ on octahedral occupancy and layer charge relations, and the status of $\mathrm{Fe}^{+3}$ in chlorites. A classification scheme based on the principal types of replacement is proposed.

\section{SELECTION OF ANALYSES}

About 150 analyses of chlorites were selected from the literature for study. These analyses are given in table 2 . In selecting analyses for study, all analyses published before 1900 were excluded. This restriction inevitably excludes some good analyses, but it also eliminates a large number that are unreliable or unsatisfactory, either because of failure to purify the analyzed sample properly, inaccurate methods of analysis-as, for example, determination of ferrous iron-or incompleteness in analyses. Next, all analyses later than 1900 in which more than 0.5 percent of $\mathrm{Na}_{2} \mathrm{O}, \mathrm{K}_{2} \mathrm{O}$, or $\mathrm{CaO}$ were reported were excluded. There is no place in the chlorite structure for cations as large as $\mathrm{Na}^{+}, \mathrm{K}^{+}$, and $\mathrm{Ca}^{+2}$, and their presence suggests interlayering or admixture with mica and (or) montmorillonite, or the presence of associated carbonates or silicates. In this connection, the high alkali content in chlorite analyses reported by Polovinkina and Ivanova (1953) may be cited. The surprisingly high alkali content reported in these analyses, as much as 4.5 percent, is attributed by the authors to intergrown relict mica. This amount of alkali indicates that a considerable proportion of the analyzed sample was mica, consequently the analyses cannot be relied on as indicative of the composition of the chlorite present. As the relation of trivalent to bivalent octahedral cations is of particular interest in this study, all analyses that did not report both $\mathrm{Fe}_{2} \mathrm{O}_{3}$ and $\mathrm{FeO}$ were also discarded.

Finally, analyses in which the amount of $\mathrm{H}_{2} \mathrm{O}$ reported was significantly low (less than 9.5 percent) or significantly high (more than 13.5 percent) were excluded. Some variation in $\mathrm{H}_{2} \mathrm{O}$ content is, of course, to be expected. Chlorites that have a high ferric-iron content, especially, may have a lower than normal $\mathrm{H}_{2} \mathrm{O}$ content. But even so, analyses reporting less than 9.5 percent $\mathrm{H}_{2} \mathrm{O}$ are highly suspect. No reason such as reduction, as opposed to oxidation, can be asserted to account for high water content. Analyses reporting significantly high water are suspect as indicating an inaccurate water determination or the presence of contaminants, like montmorillonite, that are characterized by high $\mathrm{H}_{2} \mathrm{O}$ content.

\section{STRUCTURAL FORMULAS}

\section{CALCULATION OF FORMULAS}

Structural formulas for all the analyses given in table 2 were calculated on the basis of the theoretical $\mathrm{O}(\mathrm{OH})$ content of the unit cell of chlorite, $\mathrm{O}_{20}(\mathrm{OH})_{16}$. For comparative purposes a second set of formulas were calculated on the basis of determined $\mathrm{H}_{2} \mathrm{O}(+)$ for those analyses in which $\mathrm{H}_{2} \mathrm{O}(+)$ and $\mathrm{H}_{2} \mathrm{O}(-)$ were both reported.

The method used in calculating formulas on the basis of the theoretical $\mathrm{O}(\mathrm{OH})$ content was adapted from the method used for calculating the formulas of micas (Foster, 1960) by using the number 56 instead of 44 (for the mica) to convert gram equivalents of cationic constituents to cationic valences per 
TABLE 1.-Example of calculation of the structural formula of a chlorite

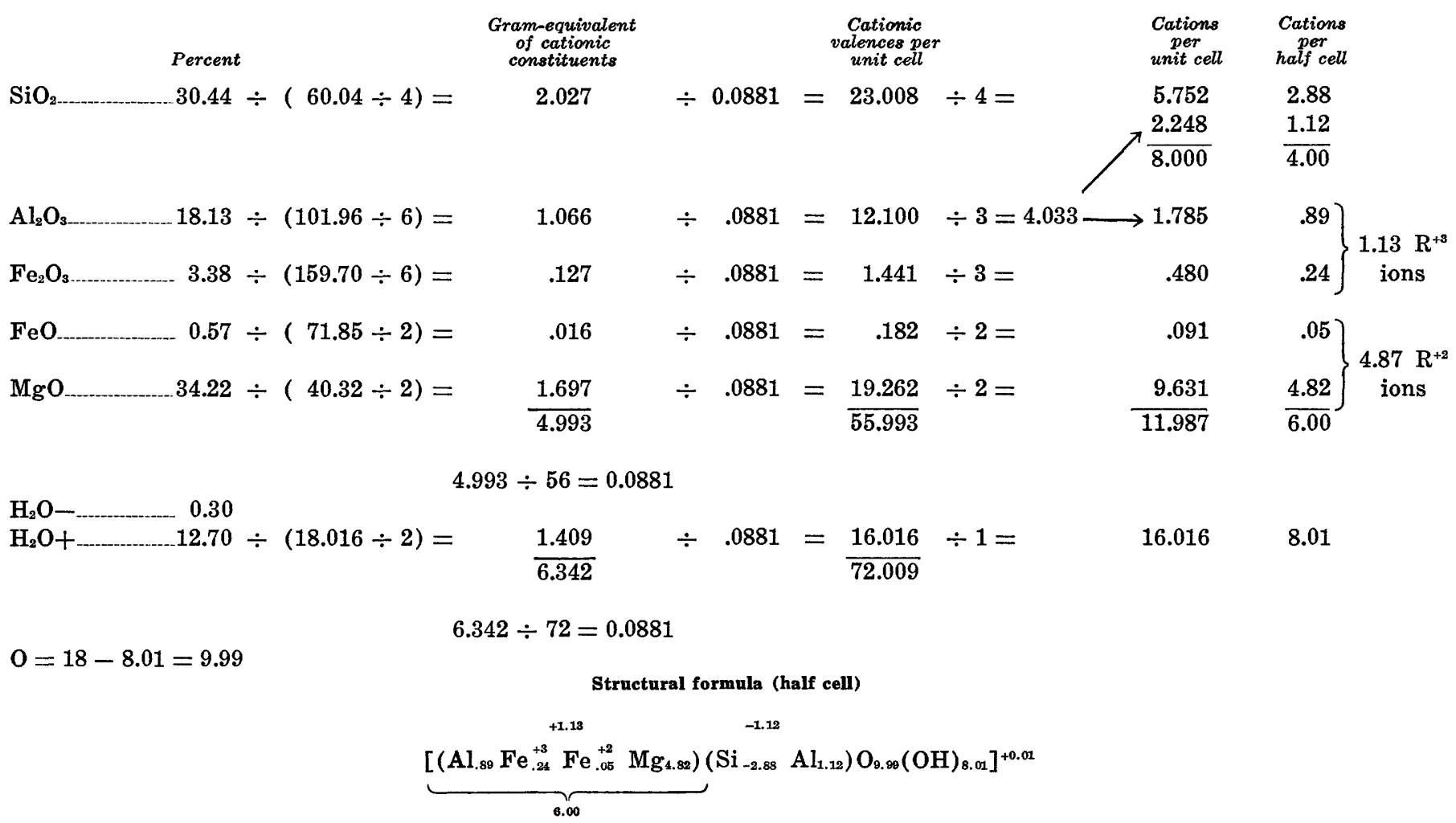

unit cell. The calculations involved are illustrated in the example shown in table 1 . The gram equivalents of cationic constituents in the structure are obtained by dividing the percent of each constituent reported in the analysis by a factor obtained by dividing the molecular weight of that constituent by the number of cationic valences in its molecular formula. Thus, for $\mathrm{Fe}_{2} \mathrm{O}_{3}$ the factor to be used is the molecular weight of $\mathrm{Fe}_{2} \mathrm{O}_{3}, 159.70$, divided by 6 , which is 26.617 ; for $\mathrm{FeO}$ it is 71.85 divided by 2 , or 35.925 .

The second step in the calculation is to convert gram equivalents of cationic constituents to cationic valences in the unit cell. The number of cationic valences must equal the number of anionic valences, which, theoretically, is 56, as each of the $20 \mathrm{O}$ ions in the unit cell carries two negative charges and each of the $16 \mathrm{OH}$ ions carries one. The sum of the gram equivalents of the cationic constituents was, therefore, divided by 56 to obtain the factor for converting the gram equivalents of each constituent to the number of cationic valences in the unit cell. After dividing the gram equivalents of each constituent by this factor, the number of valences thus obtained for each cation is then divided by its valence to obtain the number of cations of that species in the unit cell.
The aluminum ions are divided between the tetrahedral and octahedral groups; enough $\mathrm{Al}$ is allocated to the tetrahedral group to bring the total number of cations in that group, with silicon, to 8.00 , and the remainder is assigned to the octahedral group with the other cations. This assignment of Al ions to fill the tetrahedral group is in accordance with customary procedure, and does not preclude the possibility that other trivalent cations, $\mathrm{Fe}^{+3}$ or $\mathrm{Cr}^{+3}$, may not occupy such sites in certain chlorites. The sum of the octahedral cations, theoretically, should be $12.00,6.00$ in each of the octahedral layers, but in many of the calculated formulas for chlorites it is less.

Most of the discussion in this report on characteristics of the chlorites is based on the half-cell formulas. To write the half cell formula the values for the cations in the unit cell are merely halved, as in the formula at the bottom of table 1 .

\section{THEORETICAL O(OH) VERSUS DETERMINED $\mathrm{H}_{2} \mathrm{O}(+)$}

Theoretically a chlorite contains no "adsorbed" water, $\mathrm{H}_{2} \mathrm{O}(-)$; all the water present is "hydroxyl" water, $\mathrm{H}_{2} \mathrm{O}(+)$, and the figure given in the analyses for total water may thus be used in calculating the formula. However, very few of the analyses in which $\mathrm{H}_{2} \mathrm{O}(+)$ and $\mathrm{H}_{2} \mathrm{O}(-)$ were differentiated report 0.00 
percent $\mathrm{H}_{2} \mathrm{O}(-)$. Most of them report some $\mathrm{H}_{2} \mathrm{O}(-)$, the amounts ranging from a few tenths to almost 2 percent. In view of this, formulas based on determined $\mathrm{H}_{2} \mathrm{O}(+)$ were calculated only for those analyses in which both $\mathrm{H}_{2} \mathrm{O}(+)$ and $\mathrm{H}_{2} \mathrm{O}(-)$ were reported. In calculating formulas for such analyses, the value of $\mathrm{H}_{2} \mathrm{O}(+)$ was included with the cationic constituents, and the sum of the gram equivalents of cationic constituents was divided by 72 , (each of the 36 oxygen in the unit cell carrying two negative charges) instead of 56.

In the sample calculation shown in table 1 , the factor for converting gram equivalents of cationic constituents to cationic valences per unit cell is the same, 0.0881 , whether the calculation is on the basis of the theoretical $\mathrm{O}(\mathrm{OH})$ content or determined $\mathrm{H}_{2} \mathrm{O}(+)$. This indicates that the determined figure for structural water is very close to the theoretical. Factors based on determined $\mathrm{H}_{2} \mathrm{O}(+)$ that are larger or smaller than those based on the theoretical $\mathrm{O}(\mathrm{OH})$ content indicate proportionate differences, plus or minus, between the theoretical and the determined $\mathrm{OH}$ content. The greater the difference in factors the greater is the difference in the number of structural positions occupied by the various cations in the formulas based on the theoretical $\mathrm{O}(\mathrm{OH})$ content and on determined $\mathrm{H}_{2} \mathrm{O}(+)$ values.

If the factor for converting gram equivalents to cationic valences per unit cell is greater when calculated on the basis of determined $\mathrm{H}_{2} \mathrm{O}(+)$ than on the basis of theoretical $\mathrm{O}(\mathrm{OH})$ content, the number of cations of the various constituents in the half-cell formula calculated on that basis is less than that in the formula calculated on the basis of theoretical $\mathrm{O}(\mathrm{OH})$. This is illustrated in the following pair of formulas for analysis 12 , table 2 : lated on the basis of theoretical $\mathrm{O}(\mathrm{OH})$, as shown below in the pair of formulas for analysis 126, table 2 . In the first pair of formulas there is considerable excess of $(\mathrm{OH})$ and deficiency in $\mathrm{O}$ in the formula calculated on the basis of determined $\mathrm{H}_{2} \mathrm{O}(+)$ as compared with the theoretical $\mathrm{O}(\mathrm{OH})$ content. The decrease in the number of anionic charges present is reflected in the decreased number of cations present, 0.21. Magnesium occupied 0.09 fewer positions, $\mathrm{Al}(\mathrm{VI}), 0.11$; and $\mathrm{Si} 0.05$. In the second pair of formulas, the formula calculated on the basis of determined $\mathrm{H}_{2} \mathrm{O}(+)$ has considerable excess of $\mathrm{O}$ and deficiency of $\mathrm{H}$ compared with the theoretical $\mathrm{O}(\mathrm{OH})$ content. The increase in cationic charges present is reflected in the greater number of cations present, 0.37 . $\mathrm{Mg}$ occupies 0.07 more positions; $\mathrm{Fe}^{+2}$, $0.06 ; \mathrm{Fe}^{+3}, 0.03 ; \mathrm{Al}(\mathrm{VI}), 0.21 ;$ and $\mathrm{Si}, 0.11$.

The two examples above are near the extremes in variation in $\mathrm{O}$ and $\mathrm{OH}$ content found in the 65 formulas calculated on the basis of determined $\mathrm{H}_{2} \mathrm{O}(+)$. The differences in the number of formula positions occupied by the various cations between formulas calculated on the basis of determined $\mathrm{H}_{2} \mathrm{O}(+)$ and the number of positions occupied by the same cations in formulas calculated from the same analyses on the basis of the theoretical $\mathrm{O}(\mathrm{OH})$ content are not great enough to change the general character of the chlorites represented nor to change their classification, unless they happen to be on the borderline between species. In all the other analyses for which two formulas were calculated, the differences are less than in the two examples cited. It can be concluded, therefore, that for a study of the general characteristics of chlorites as a group, formulas calculated on the basis of the theoretical $\mathrm{O}(\mathrm{OH})$ content are entirely satisfactory.

Determined $\mathrm{H}_{2} \mathrm{O}(+)$, factor $=0.0907 \ldots \underbrace{\left[\mathrm{Al}_{1.41} \mathrm{Fe}_{.11}^{+8} \mathrm{Mg}_{4.15}\right)}_{5.67}\left(\mathrm{Si}_{2.58} \mathrm{Al}_{1.42}\right) \mathrm{O}_{8.42}(\mathrm{OH})_{8.58}]$

Theoretical $\mathrm{O}(\mathrm{OH})$, factor $=0.0889 \ldots\left[\left(\mathrm{Al}_{1.52} \mathrm{Fe}_{.12}^{+3} \mathrm{Mg}_{4.24}\right)\left(\mathrm{Si}_{2.88} \mathrm{Al}_{1.87}\right) \mathrm{O}_{10}(\mathrm{OH})_{8}\right]$

5.88

If the reverse relationship applies, the number of cations of the various constituents in the halfcell formula calculated on the basis of determined $\mathrm{H}_{2} \mathrm{O}(+)$ is greater than that in the formula calcu-
The temperatures at which $\mathrm{H}_{2} \mathrm{O}(-)$ is usually determined, $100^{\circ}$ or $110^{\circ} \mathrm{C}$, were fixed long before thermal analysis techniques were developed. Studies of chlorites by such techniques show that adsorbed

Determined $\mathrm{H}_{2} \mathrm{O}(+)$, factor $=0.0791 \underbrace{\left[\left(\mathrm{Al}_{1.81} \mathrm{Fe}_{.88}^{+3} \mathrm{Fe}_{1.70}^{+2} \mathrm{Mg}_{1.86}\right.\right.}_{\text {5.83 }})\left(\mathrm{Si}_{2.86} \mathrm{Al}_{1.04}\right) \mathrm{O}_{11.10}(\mathrm{OH})_{8.80}]$

Theoretical $\mathrm{O}(\mathrm{OH})$, factor $=0.0820 \ldots\left[\left(\mathrm{Al}_{1.40} \mathrm{Fe}_{.83}^{+3} \mathrm{Fe}_{1.04}^{+2} \mathrm{Mg}_{1.88}\right)\left(\mathrm{Si}_{2.85} \mathrm{Al}_{1.16}\right) \mathrm{O}_{10}(\mathrm{OH})_{8}\right]$ 
water, $\mathrm{H}_{2} \mathrm{O}(-)$, continues to be given off to temperatures as high as $500^{\circ} \mathrm{C}$. Determination of $\mathrm{H}_{2} \mathrm{O}(-)$ at $100^{\circ}$ or $110^{\circ} \mathrm{C}$ would tend, therefore, to give a low $\mathrm{H}_{2} \mathrm{O}(-)$ value, and a high $\mathrm{H}_{2} \mathrm{O}(+)$ value, and the factor for converting gram equivalents to cationic valences per unit cell would be correspondingly high. Low values for $\mathrm{H}_{2} \mathrm{O}(+)$ and, consequently lower factors than those based on the theoretical $\mathrm{O}(\mathrm{OH})$ values, as illustrated in the second pair of formulas above, may be due to oxidation of $\mathrm{FeO}$ to $\mathrm{Fe}_{2} \mathrm{O}_{3}$ during the $\mathrm{H}_{2} \mathrm{O}(+)$ determination, in accordance with the reaction, $2 \mathrm{Fe}(\mathrm{OH})_{2}=2 \mathrm{FeO}(\mathrm{OH})+\mathrm{H}_{2}$. This reaction requires the conversion of one $(\mathrm{OH})$ to $\mathrm{O}$ for each ion of $\mathrm{Fe}^{+2}$ oxidized to $\mathrm{Fe}^{+3}$.

Low $\mathrm{H}_{2} \mathrm{O}(+)$ values and low factors for converting gram-equivalents to cationic valences per unit cell could also be produced by secondary oxidation of $\mathrm{FeO}$ to $\mathrm{Fe}_{2} \mathrm{O}_{3}$ in place. Thus chlorites that have undergone secondary oxidation should be characterized by a low $\mathrm{H}_{2} \mathrm{O}(+)$ value and by a low conversion factor as compared with the theoretical. Such low values for $\mathrm{H}_{2} \mathrm{O}(+)$ would be more to be expected in chlorites containing considerable $\mathrm{Fe}_{2} \mathrm{O}_{3}$, like the chlorite represented by the second pair of formulas above, which contains 8.33 percent $\mathrm{Fe}_{2} \mathrm{O}_{3}$. In some analyses, however, the $\mathrm{H}_{2} \mathrm{O}(+)$ content and the conversion factor used in calculating the formulas on the basis of determined $\mathrm{H}_{2} \mathrm{O}(+)$ is so low that the octahedral occupancy is considerably greater than 6.00 , whereas formulas calculated on the basis of the theoretical $\mathrm{O}(\mathrm{OH})$ content have octahedral occupancies of 6.00 or less, as in the following examples:

Analysis 1 , table $2\left(\mathrm{Fe}_{2} \mathrm{O}_{3}=3.42\right.$ percent $)$,
The $\mathrm{H}_{2} \mathrm{O}(+)$ content reported in the analyses from which these formulas were calculated is much lower than can be accounted for by secondary oxidation of $\mathrm{Fe}^{+2}$. The high octahedral occupancies obtained when these $\mathrm{H}_{2} \mathrm{O}(+)$ values are used in calculating the formulas strongly suggest that the $\mathrm{H}_{2} \mathrm{O}(+)$ values reported are in error, and do not represent the true hydroxyl content of the samples.

In formulas like these, in which the use of the determined $\mathrm{H}_{2} \mathrm{O}(+)$ value yields an octahedral occupancy significantly greater than 6.00 , the erroneous nature of the $\mathrm{H}_{2} \mathrm{O}(+)$ value is obvious, but for chlorites in which the octahedral occupancy is considerably less than 6.00 , a low $\mathrm{H}_{2} \mathrm{O}(+)$ value might still produce a formula in which octahedral occupancy is no more than 6.00 , and the possibility that the $\mathrm{H}_{2} \mathrm{O}(+)$ value is low is not so obvious. Nor does a high value for $\mathrm{H}_{2} \mathrm{O}(+)$ produce a formula that is obviously suspect. A high value for $\mathrm{H}_{2} \mathrm{O}(+)$ yields a conversion factor that is higher than that obtained on the basis of the theoretical $\mathrm{O}(\mathrm{OH})$ content. Consequently the number of octahedral cations is lower than that obtained if the factor based on the theoretical $\mathrm{O}(\mathrm{OH})$ content is used. If both are 6.00 or less, there is no reason for suspecting the determined $\mathrm{H}_{2} \mathrm{O}(+)$ value, unless there is considerable discrepancy between the two values, for which no reasonable explanation can be advanced, such as secondary oxidation of $\mathrm{Fe}^{+2}$.

\section{RELATION BETWEEN $\mathrm{Fe}^{+3}$ AND O}

By regarding the $\mathrm{Fe}_{2} \mathrm{O}_{3}$ in chlorites as the result of secondary oxidation of $\mathrm{FeO}$, Winchell (1926) was

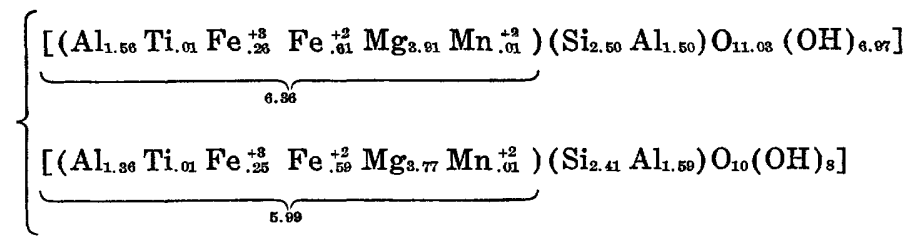

Analysis 33 , table $5\left(\mathrm{Fe}_{2} \mathrm{O}_{3}=0.83\right.$ percent $)$,

$$
\left\{\begin{array}{l}
\underbrace{\left[\left(\mathrm{Al}_{1.44} \mathrm{Fe}_{.06}^{+3} \mathrm{Fe}{ }_{.84}^{+2} \mathrm{Mg}_{4.42}\right)\right.}_{0.26}\left(\mathrm{Si}_{2.80} \mathrm{Al}_{1.11}\right) \mathrm{O}_{10.88}(\mathrm{OH})_{7.14}] \\
\underbrace{\left[\left(\mathrm{Al}_{1.27} \mathrm{Fe}_{.08}^{+8} \mathrm{Fe}_{.31}^{+2} \mathrm{Mg}_{4.20}\right)\right.}_{5.83}\left(\mathrm{Si}_{2.80} \mathrm{Al}_{1.20}\right) \mathrm{O}_{10}(\mathrm{OH})_{8}]
\end{array}\right.
$$

Analysis 133, table $2\left(\mathrm{Fe}_{2} \mathrm{O}_{3}=2.81\right.$ percent $)$,

$$
\left\{\begin{array}{l}
\underbrace{\left[\left(\mathrm{Al}_{1.40} \mathrm{Ti}_{.02} \mathrm{Fe}_{.23}^{+3} \mathrm{Fe}_{2.42}^{+2} \mathrm{Mg}_{2.10}\right)\right.}_{6.17}\left(\mathrm{Si}_{3.28} \mathrm{Al}_{.72}\right) \mathrm{O}_{11.27}(\mathrm{OH})_{6.73}] \\
\underbrace{\left[\mathrm{Al}_{1.16} \mathrm{Ti}_{.02} \mathrm{Fe}_{.22}^{+3} \mathrm{Fe}_{2.81}^{+2} \mathrm{Mg}_{2.01}\right)}_{5.72}\left(\mathrm{Si}_{8.13} \mathrm{Al}_{.87}\right) \mathrm{O}_{10}(\mathrm{OH})_{8}]
\end{array}\right.
$$




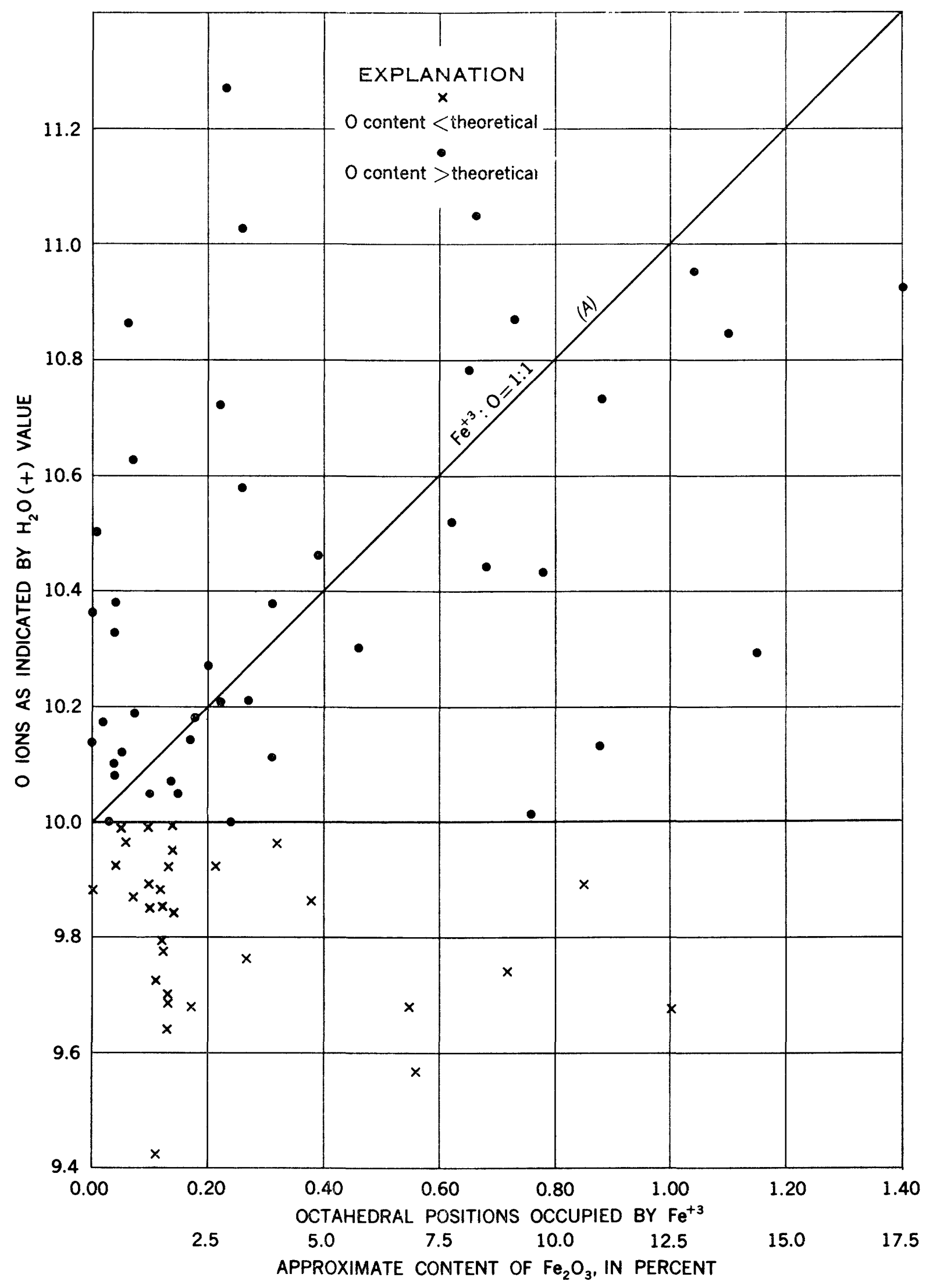

Figure 1.-Relation between $\mathrm{Fe}^{+8}$ and $\mathrm{O}$ in chlorites. 
able to reduce some leptochlorites to orthochlorite composition, but others could not be reduced to orthochlorite composition in this way. Following Winchell, Holzner (1938) also showed that many analyses of leptochlorites are reduced to orthochlorite composition when all the $\mathrm{Fe}_{2} \mathrm{O}_{3}$ is reduced to $\mathrm{FeO}$. He explained the secondary oxidation of $\mathrm{Fe}^{+2}$ to $\mathrm{Fe}^{+3}$ in terms of the following reaction,

$$
2 \mathrm{Fe}(\mathrm{OH})_{2}=2 \mathrm{FeO}(\mathrm{OH})+\mathrm{H}_{2}
$$

This reaction requires the conversion of one $\mathrm{OH}$ to $\mathrm{O}$ for each ion of $\mathrm{Fe}^{+2}$ oxidized to $\mathrm{Fe}^{+3}$. Thus chlorites that have undergone secondary oxidation should be characterized by an $O$ content greater that 10 ions per half-cell by an amount equivalent to the $\mathrm{Fe}^{+3}$ present.

To study the relation between $\mathrm{Fe}^{+3}$ and $\mathrm{O}$ in chlorites, the number of positions occupied by $\mathrm{Fe}^{+3}$ was plotted against the number of positions occupied by $O$ in formulas calculated from analyses reporting both $\mathrm{H}_{2} \mathrm{O}(+)$ and $\mathrm{H}_{2} \mathrm{O}(-)$, as shown in figure 1 . The approximate amount of $\mathrm{Fe}_{2} \mathrm{O}_{3}$ as reported in the analyses is indicated below the number of formula positions occupied by $\mathrm{Fe}^{+3}$. The hypothetical relation between $\mathrm{Fe}^{+3}$ and $\mathrm{O}$ in excess of the 10 oxygen ions in the half cell, according to the above equation, is indicated by the diagonal line A (fig. 1). The location of most of the points indicates that there is little relation in these chlorites between $\mathrm{Fe}^{+3}$ and $\mathrm{O}$ calculated from the $\mathrm{H}_{2} \mathrm{O}(+)$ values given in the analyses. A few points indicate an $\mathrm{O}$ content high with respect to $\mathrm{Fe}^{+3}$, and several points, some representing chlorites containing considerable $\mathrm{Fe}^{+3}$, indicate an $\mathrm{O}$ content of less than 10. As has already been pointed out, determined $\mathrm{H}_{2} \mathrm{O}(+)$ values tend to be high rather than low because they include some $\mathrm{H}_{2} \mathrm{O}(-)$ water. The fact that $\mathrm{O}$ is low with respect to $\mathrm{Fe}^{+3}$ in most of the chlorites represented in figure 1 lends little support to the hypothesis of secondary oxidation.

\section{RELATION BETWEEN TETRAHEDRAL AND OCTAHEDRAL Al}

Substitution of $\mathrm{Al}^{+3}$, or other trivalent ion, for $\mathrm{Si}^{+4}$ gives the tetrahedral layers a negative charge equivalent to the amount of $\mathrm{R}^{+3}$ proxying for $\mathrm{Si}^{+4}$. For structural balance the octahedral layers must have a corresponding positive charge, and, consequently, must contain at least as many $\mathbf{R}^{+3}$ ions as the tetrahedral layers, as illustrated in the following formulas :

$$
\underbrace{\left[\mathrm{Al}_{1.50}\left(\mathrm{Fe}^{++2}, \mathrm{Mg}\right)_{4.50}^{+1.50}\right.}_{6.00}]\left(\mathrm{Si}_{2.50}^{-1.50} \mathrm{Al}_{1.50}\right) \mathrm{O}_{10}(\mathrm{OH})_{8}
$$

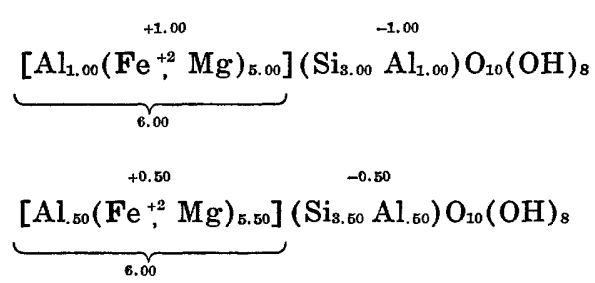

Thus, theoretically, octahedral $\mathrm{Al}$ should be equivalent to tetrahedral Al. However, in most formulas calculated from analyses of chlorites, octahedral $\mathrm{Al}$ is either greater or less than tetrahedral Al. The relation between tetrahedral and octahedral $\mathrm{Al}$ in the formulas calculated from the analyses in table 2 is shown in figure 2. In this figure the $1: 1$ relation between tetrahedral and octahedral $\mathrm{Al}$ is represented by diagonal line $\mathrm{A}$. In most of the chlorites represented, octahedral $\mathrm{Al}$ is less than tetrahedral $\mathrm{Al}$, although some show a contrary relation; in relatively few is octahedral $\mathrm{Al}$ just equivalent to tetrahedral $\mathrm{Al}$. In some of the latter, $\mathrm{Al}$ may represent the entire octahedral $R^{+3}$ present, as in the following formula for analysis 59 , table 2 ,

$$
\left.[\underbrace{\left(\mathrm{Al}_{.90} \mathrm{Fe}_{.73}^{+2} \mathrm{Mg}_{4.81}^{+.98} \mathrm{Mn} .01\right.}_{0.01})\left(\mathrm{Si}_{3.00}^{+1.00} \mathrm{Al}_{1.00}\right) \mathrm{O}_{10}(\mathrm{OH})_{8}\right]^{-0.02}
$$

in others it may make up only part of the octahedral $R^{+3}$ present, as in this formula for analysis 123 , table 2 ,

$$
[\underbrace{\left(\mathrm{Al}_{1.16} \mathrm{Fe}_{.46}^{+3} \mathrm{Fe}_{2.38}^{+1.16} \mathrm{Mg}_{1.82}\right)}_{6.77}\left(\mathrm{Si}_{2.84}^{-1.18} \mathrm{Al}_{1.16}\right) \mathrm{O}_{10}(\mathrm{OH})_{8}]^{0.00}
$$

In the first of these formulas $\mathrm{Al}$ makes up all the trivalent octahedral cation and is about equivalent to tetrahedral $\mathrm{Al}$, and octahedral occupancy is 6.01 , but in the second formula, octahedral $\mathrm{Al}$ is equivalent to tetrahedral $\mathrm{Al}$ but makes up only part of the $R^{+3}$ octahedral cations, and octahedral occupancy is only 5.77 , a deficiency of 0.23 positions. If $\mathrm{Al}$ were the only trivalent octahedral cation in this second formula, it may be assumed that, as in the first formula, octahedral occupancy would be complete and that $\mathrm{R}^{+2}$ would occupy 4.84 positions. However, $\mathrm{R}^{+2}$ occupies only 4.15 positions, or 0.69 position less, and $\mathrm{Fe}^{+3}$ occupies 0.46 . It is evident, therefore, that $\mathrm{Fe}^{+3}$ has replaced $\mathrm{R}^{+2}$ in the ratio of $2: 3$, and that the 0.46 negative charge associated with the 0.23 unoccupied octahedral position neutralizes the 0.46 extra positive charge carried by $\mathrm{Fe}^{+3}$, as compared with the amount of charge that would have been carried by the same amount of a bivalent cation. 


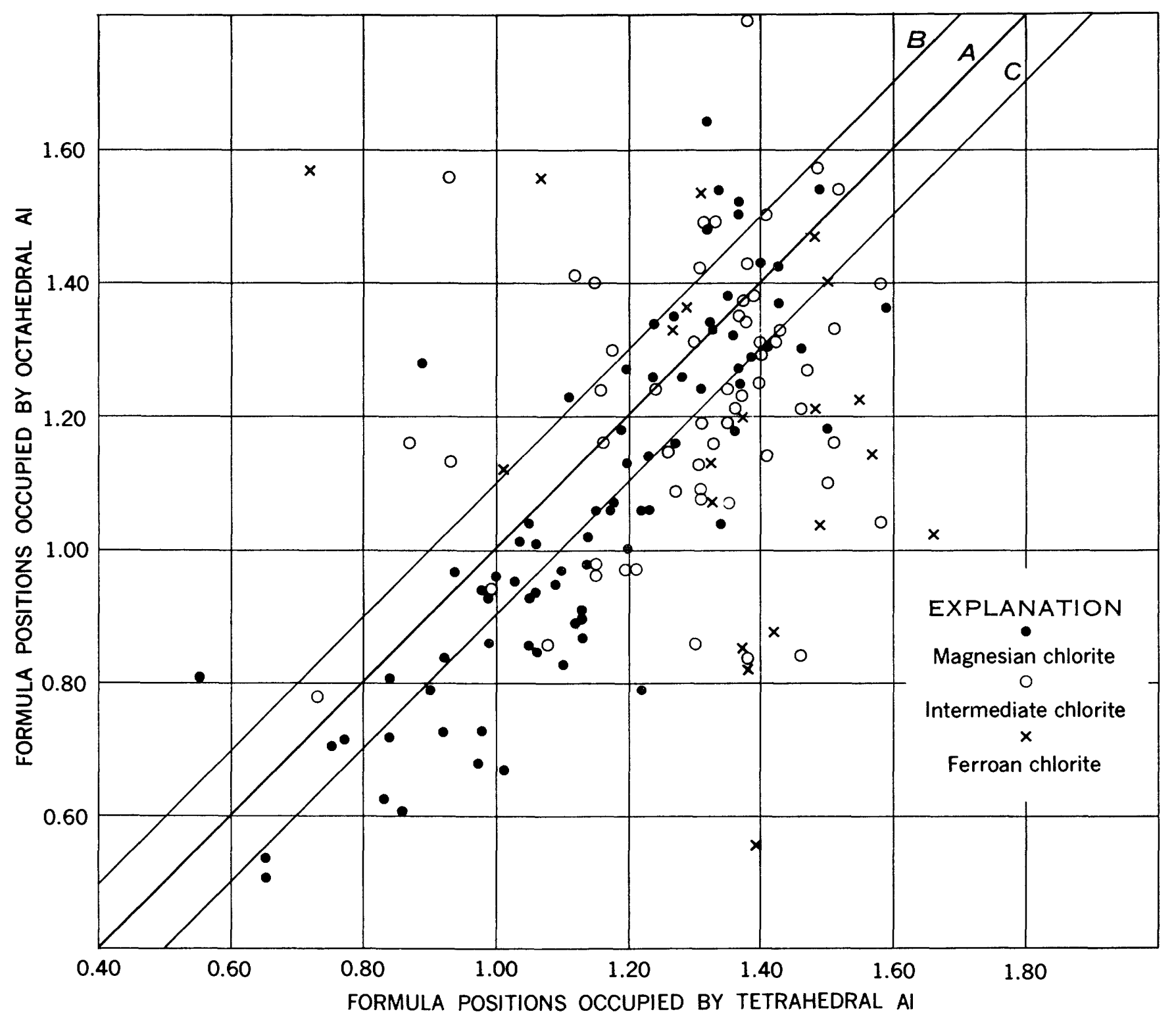

Figure 2.-Relation between tetrahedral Al and octrahedral Al.

In chlorites represented by points falling above line A (fig. 2) octahedral Al is greater than tetrahedral Al. In some of these chlorites $\mathrm{Al}$ is about the only trivalent octahedral cation present, as in these formulas calculated from analysis 101, table 2 ,

$$
+1.40
$$

$\left[\left(\mathrm{Al}_{1.82} \mathrm{Ti}_{.01} \mathrm{Fe}_{.04}^{+8} \mathrm{Fe}_{2.71}^{+2} \mathrm{Mg}_{1.13} \mathrm{Mn}_{.05}^{+2}\right)\left(\mathrm{Si}_{2.02} \mathrm{Al}_{1.88}\right) \mathrm{O}_{10}(\mathrm{OH})_{8}\right]^{+0.02}$

and from analysis 17 , table 2 ,

$\underbrace{\left[\left(\mathrm{Al}_{1.54} \mathrm{Fe}_{.02}^{+1.34} \mathrm{Fe}_{.08}^{+2} \mathrm{Mg}_{4.30}\right.\right.}_{5.89})\left(\mathrm{Si}_{2.68}^{-1.84} \mathrm{Al}_{1.34}\right) \mathrm{O}_{10}(\mathrm{OH})_{8}]^{0.00}$
In the first formula, 1.40 of the extra charges carried by $\mathrm{Al}$ form a positive charge on the octahedral layers, neutralizing the negative tetrahedral charge. The rest of the $\mathrm{Al}$, and all the $\mathrm{Fe}^{+3}$ (and Ti), occupying 0.47 positions, may be interpreted as replacing $R^{+2}$ in the 2:3 ratio, with the 0.48 negative charge associated with the 0.24 unoccupied octahedral position neutralizing the extra 0.48 positive charge they carry. Similarly in the second formula, $1.34 \mathrm{Al}$ provides the positive charge on the octahedral layers, with the rest of the $\mathrm{Al}$ and the $\mathrm{Fe}^{+3}, 0.22$, replacing $R^{r 2}$ in the 2:3 ratio. In other formulas in which octahedral $\mathrm{Al}$ exceeds tetrahedral $\mathrm{Al}$, other trivalent 
cations are also present in significant amounts, as in the following formulas for analysis 148 , table 2 ,

$$
\underbrace{\left[\left(\mathrm{Al}_{1.63} \mathrm{Fe}_{.61}^{+1.30} \mathrm{Fe}_{2.86}^{+2} \mathrm{Mg}_{.68}\right)\right.}_{6.68}\left(\mathrm{Si}_{2.60}^{-1.81} \mathrm{Al}_{1.81}\right) \mathrm{O}_{10}(\mathrm{OH})_{8}]^{-0.01}
$$

and for analysis 128 , table 2 ,

$$
\underbrace{\left[\left(\mathrm{Al}_{1.41} \mathrm{Fe}_{.73}^{+1.12} \mathrm{Fe}_{1.88}^{+2} \mathrm{Mg}_{1.47}\right.\right.}_{5.40})\left(\mathrm{Si}_{2.88}^{-1.12} \mathrm{Al}_{1.12}\right) \mathrm{O}_{10}(\mathrm{OH})_{8}]^{0.00}
$$

In these formulas, as in the two preceding, octahedral $R^{+3}$ in excess of that necessary to provide a positive charge sufficient to neutralize the negative tetrahedraI charge may be interpreted as replacing $\mathrm{R}^{+2}$ in the $2: 3$ ratio, as indicated by the deficiency in the number of octahedral positions occupied.

Formulas like those for analyses 101 and 17, in which octahedral $\mathrm{Al}$ is considerably in excess of tetrahedral Al, probably represent the type of leptochlorite that Winchell (1926) and Holzner (1938) could not reduce to orthochlorite composition. Formulas like those for analyses 148 and 128 represent the type of leptochlorite that can be partly reduced to orthochlorite composition because of the $\mathrm{Fe}^{+3}$ present, and formulas like those for analysis 123 represent the type that can be completely reduced to orthochlorite composition, because octahedral $\mathrm{R}^{+3}$ in excess of that needed for structural balance is due entirely to $\mathrm{Fe}^{+3}$.

Points falling below line A represent chlorites in which octahedral $\mathrm{Al}$ is lower that tetrahedral $\mathrm{Al}$. In such formulas other trivalent cations, like $\mathrm{Fe}^{+3}$ or $\mathrm{Cr}^{+3}$, are necessary to give the octahedral layers a positive charge great enough to neutralize the negative tetrahedral charge. For example, in the formulas for analysis 136, table 2,

$$
\left.[\underbrace{\left(\mathrm{Al}_{.88} \mathrm{Fe}_{.78}^{+3} \mathrm{Fe}_{3.68}^{+2} \mathrm{Mg}_{.72}\right.}_{6.00})\left(\mathrm{Si}_{2.42}^{-1.68} \mathrm{Al}_{1.58}\right) \mathrm{O}_{10}(\mathrm{OH})_{8}\right]^{+0.01}
$$

for analysis 45 , table 2 ,

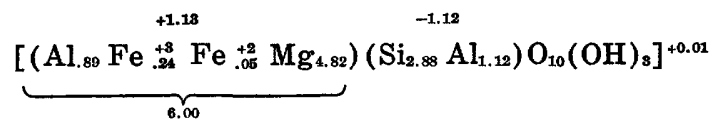

and for analysis 70 , table 2 ,

$$
\left.[\underbrace{\left(\mathrm{Al}_{.61} \mathrm{Fe}{ }_{.20}^{+0.88} \mathrm{Fe}{ }_{.11}^{+2} \mathrm{Mg}_{5,00}\right.}_{6.02})\left(\mathrm{Si}_{8.14}^{-0.88} \mathrm{Al}_{.88}\right) \mathrm{O}_{10}(\mathrm{OH})_{8}\right]^{-0.08}
$$

all the $\mathrm{Al}$ and $\mathrm{Fe}^{+3}$ are necessary to provide the octahedral layers with sufficient positive charge to neutralize the negative tetrahedral charge. In these formulas octahedral $\mathrm{Al}$ is significantly lower than tetrahedral $\mathrm{Al}$, and $\mathrm{Fe}^{+3}$ may be interpreted here as replacing $\mathrm{Al}$ in a $1: 1$ ratio. That $\mathrm{Fe}^{+3}$ replaces $\mathrm{Al}$ in this ratio and does not replace $R^{+2}$ in the $2: 3$ ratio is indicated by the octahedral occupancy, which is 6.00 or very nearly so. In some of the other chlorites represented by points below line $\mathrm{A}$ in figure 2 , some but not all of the $\mathrm{Fe}^{+3}$ is necessary to give the octahedral layers sufficient positive charge, as illustrated in these formulas for analysis 88 , table 2 ,

$$
\begin{aligned}
& +1.45 \quad-1.46 \\
& \left.\left[\begin{array}{lll}
\left(\mathrm{Al}_{.84} \mathrm{Fe}_{1.15}^{+8}\right. & \mathrm{Fe}_{2.51}^{+2} & \mathrm{Mg}_{.70} \mathrm{Mn} \\
.+58
\end{array}\right)\left(\mathrm{Si}_{2.54} \mathrm{Al}_{1.48}\right) \mathrm{O}_{10}(\mathrm{OH})_{8}\right]^{-0.01} \\
& \text { 5.73 }
\end{aligned}
$$

and for analysis 129 , table 2 ,

$$
\left.[\underbrace{\left(\mathrm{Al}_{.86} \mathrm{Ti}_{.02} \mathrm{Fe}_{1.01}^{+8} \mathrm{Fe}_{1.63}^{+2} \mathrm{Mg}_{2.13}\right.}_{5.68})\left(\mathrm{Si}_{2.02}^{-1.08} \mathrm{Al}_{1.08}\right) \mathrm{O}_{10}(\mathrm{OH})_{8}\right]^{-0.01}
$$

In the first formula, $0.61 \mathrm{Fe}^{+3}$ may be interpreted as having replaced $0.61 \mathrm{Al}$, and $0.54 \mathrm{Fe}^{+3}$ as having replaced $0.82 \mathrm{Mg}$, as indicated by the deficiency in total octahedral positions occupied. The second formula may be similarly interpreted; part of the $\mathrm{Fe}^{+3}$ (+Ti) as having replaced $\mathrm{Al}$ in a $1: 1$ ratio and part as having replaced $R^{+2}$ in a $2: 3$ ratio.

From the foregoing discussion it may be concluded that there is great variability in the relation between tetrahedral and octahedral $\mathrm{Al}$ in chlorites. In relatively few chlorites is octahedral $\mathrm{Al}$ equivalent to tetrahedral $\mathrm{Al}$ with $\mathrm{R}^{+2}$ occupying the rest of the octahedral positions, so that octahedral occupancy is close to 6.00. Octahedral $\mathrm{Al}$ in excess of tetrahedral $\mathrm{Al}$, plus any other trivalent octahedral cation present, such as $\mathrm{Fe}^{+3}$, replaces $\mathrm{R}^{+2}$ cations in a $2: 3$ ratio, and octahedral occupancy is consequently deficient by an equivalent amount. In other chlorites octahedral $\mathrm{Al}$ is less than tetrahedral $\mathrm{Al}$ and some other trivalent cation, usually $\mathrm{Fe}^{+3}$, is necessary for structural balance. In some of these chlorites in which octahedral $\mathrm{Al}$ is low, the other trivalent cations are just sufficient to provide enough positive charges to balance the negative tetrahedral charge and the octahedral occupancy is close to 6.00. In such chlorites $\mathrm{Fe}^{+3}$, or other trivalent cation, replaces $\mathrm{Al}$ in a 1:1 ratio. In some other chlorites in which octahedral Al is low, the other trivalent cations present are more than sufficient to balance the negative tetrahedral charge and octahedral occupancy is deficient. In such chlorites enough of the $\mathrm{Fe}^{+3}$ (or other trivalent octahedral cation) to provide structural balance replaces octahedral $\mathrm{Al}$ in a $1: 1$ ratio, and the excess replaces $R^{+2}$ in a $2: 3$ ratio, making the 
number of octahedral positions occupied deficient by an amount equivalent to one-half the number of excess trivalent octahedral cations.

This relation between octahedral occupancy and the number of trivalent (and quadrivalent) octahedral cations in excess of trivalent tetrahedral cations is illustrated in figure 3 . The points fall along a straight line, showing that the deficiency in octahedral occupancy is always equal to approximately one-half the number of trivalent (and quadrivalent) octahedral cations in excess of tetrahedral trivalent cations. For example, a chlorite having $0.20 \mathrm{R}^{+3}$ octahedral cations in excess of $\mathrm{R}^{+3}$ tetrahedral cations has an octahedral occupancy of about 5.90, one with $0.50 \mathrm{R}^{+3}$ octahedral cations in excess has an octahedral occupancy of about 5.75, and one with 1.00 $\mathrm{R}^{+3}$ octahedral cations in excess has an octahedral occupancy of about 5.50. The points that fall farthest below the line represent chlorites that contain some Ti, which carries two more positive charges than a bivalent cation.

Figure 3 also illustrates the extent to which re-

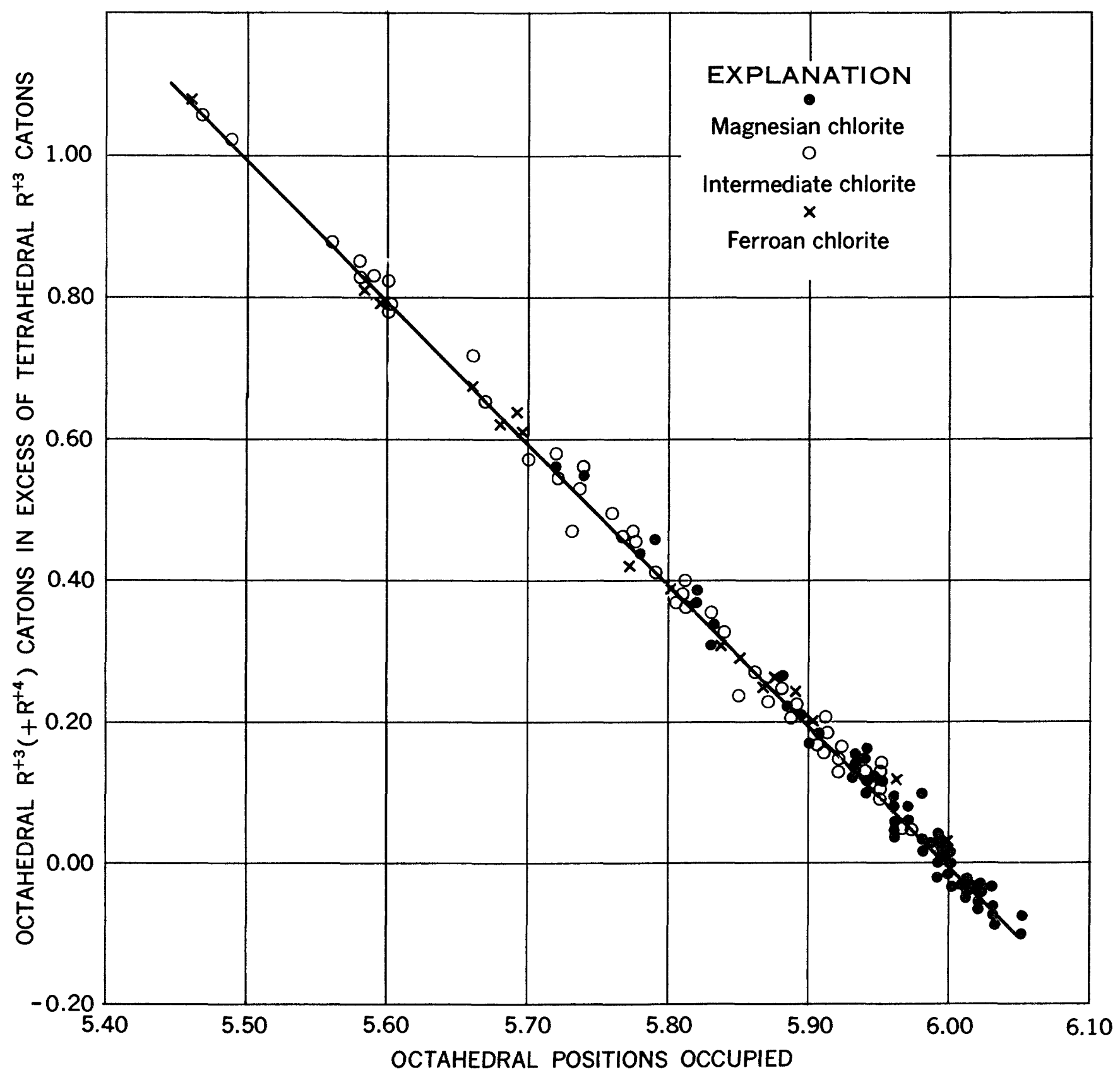

FIGURE 3.-Relation between octahedral occupancy and octahedral $R^{+8}$ (and $R^{+4}$ ) cations in excess of tetrahedral $R^{+8}$ cations. 
placement of trivalent for bivalent cations in the 2:3 ratio takes place in chlorites. Most chlorites show some replacement of this type; in many it is very slight, less than 0.20 octahedral positions; in others it is moderate, between 0.20 and 0.50 positions, and in a few it is even higher, with $R^{+3}$ cations occupying more than 0.50 octahedral positions in excess of those necessary for structural balance. In some chlorites these excess trivalent octahedral cations are made up entirely of $\mathrm{Al}$, in others entirely of $\mathrm{Fe}^{+3}$, and in still others of both $\mathrm{Al}$ and $\mathrm{Fe}^{+3}$, assuming Al to be the primary trivalent octahedral cation, as in the ideal formula.

\section{RELATION BETWEEN Si AND $\mathbf{F e}^{+2}: \mathbf{R}^{+2}$}

Pauling (1930) and Brindley and Robinson (1951) state that Si occupancy of tetrahedral positions in chlorites varies between 2.00 and 3.00 , but Hey (1954) classifies the chlorites within the limits of 2.00 and 4.00 Si positions per half cell, with the area between 3.50 and $4.00 \mathrm{Si}$ positions assigned to talcchlorites. However, in the formulas calculated from the analyses in table 2, Si varied between 2.34 and 3.45 positions, but in only one does Si occupy fewer than 2.40 positions (2.34), and in only one does it occupy more than 3.40 positions.

The relations between the number of positions occupied by $\mathrm{Si}$ and the ratio $\mathrm{Fe}^{+2}: \mathrm{R}^{+2}$ in the calculated formulas is shown in figure 4. Hey (1954) divided chlorites into two series, using the arbitrary figure of 4 percent $\mathrm{Fe}_{2} \mathrm{O}_{3}$ as the dividing line between the two types. In figure 4 the chlorites containing more than 4 percent $\mathrm{Fe}_{2} \mathrm{O}_{3}$ are distinguished symbolically. The distribution of points in figure 4 indicates that in chlorites in which $\mathrm{Fe}^{+2}: \mathrm{R}^{+2}$ is less than 0.45 , a $\mathrm{Fe}_{2} \mathrm{O}_{3}$ content of more than 4 percent is unusual, only 10 of 92 containing more than 4 percent $\mathrm{Fe}_{2} \mathrm{O}_{3}$, but that in chlorites in which $\mathrm{Fe}^{2+}: \mathrm{R}^{+2}$ is more than 0.45 , a content of more than 4 percent $\mathrm{Fe}_{2} \mathrm{O}_{3}$

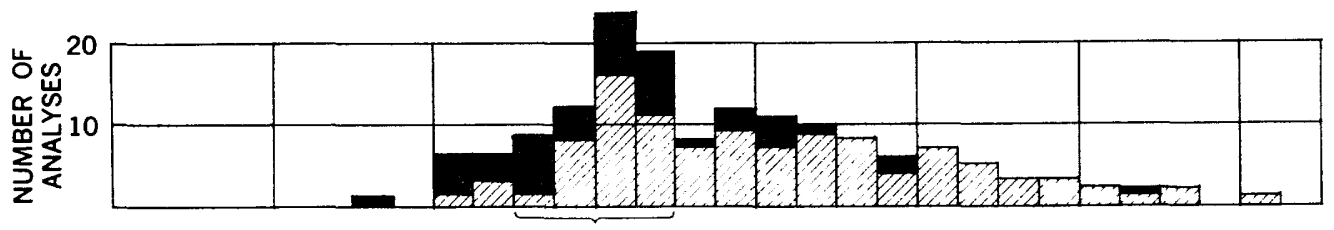

63

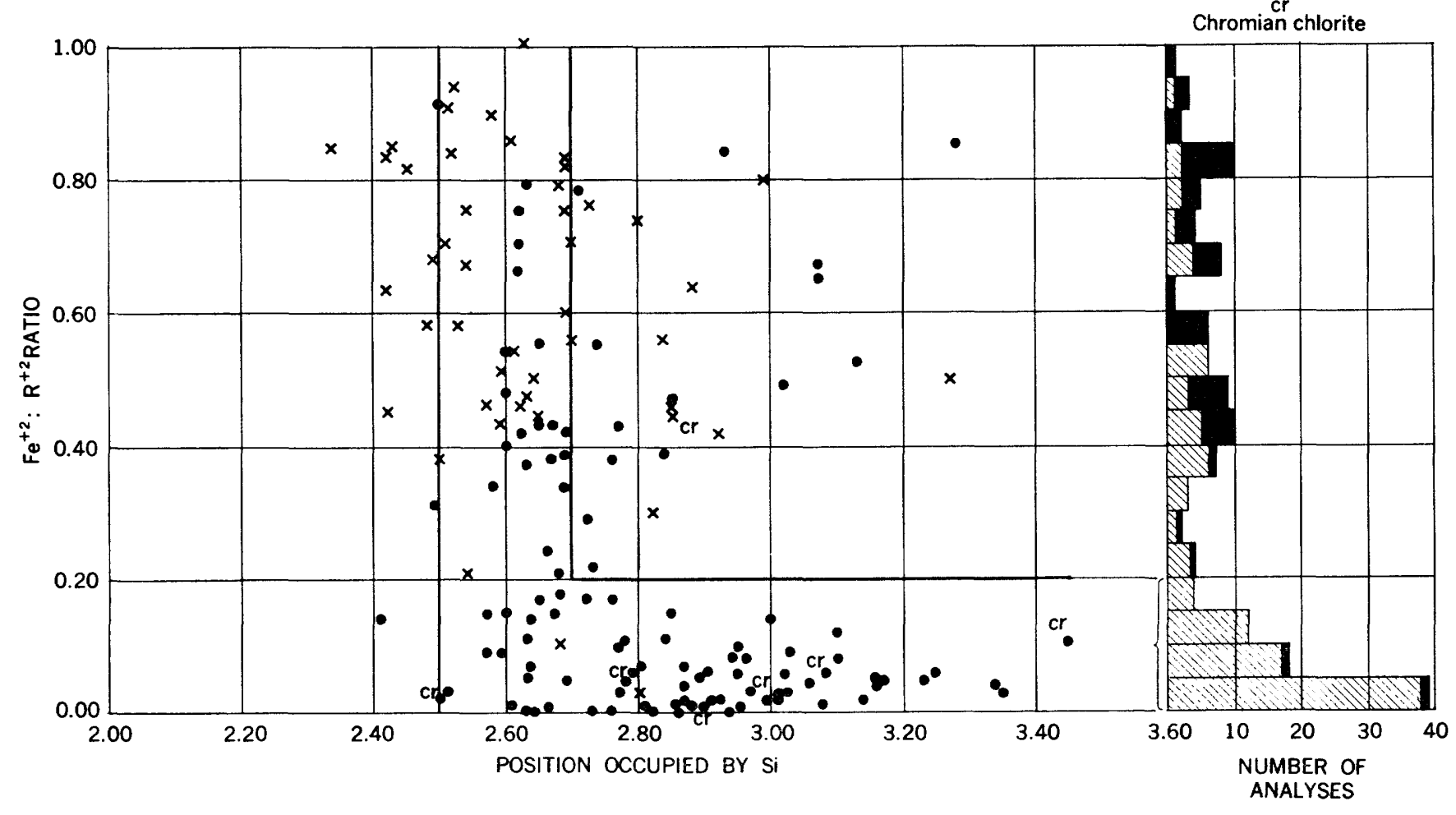

EXPLANATION QDZA

$\mathrm{Fe}_{2} \mathrm{O}_{3}<4$ percent

$\mathrm{Fe}_{2} \mathrm{O}_{3}>4$ percent

$\mathrm{Fe}_{2} \mathrm{O}_{3}<4$ percent

$\mathrm{Fe}_{2} \mathrm{O}_{3}>4$ percent

Chromian chlorite

FIGURE 4.-Relation between formula positions occupied by $\mathrm{Si}$ and the $\mathrm{Fe}^{+2}: \mathrm{R}^{+2}$ ratio. 
is to be expected, 37 out of $\mathbf{5 5}$ containing more than 4 percent $\mathrm{Fe}_{2} \mathrm{O}_{3}$. The distribution of points also indicates that most of the points representing chlorites in which $\mathrm{Fe}^{+2}: \mathrm{R}^{+2}$ is greater than 0.50 , that is, chlorites in which $\mathrm{Fe}^{+2}$ is the dominant bivalent octahedral cation, fall in the lower part of the Si range, below Si 2.70 (formula positions), and that most of the points representing chlorites in which $\mathrm{Fe}^{+2}: \mathrm{R}^{+2}$ is less than 0.50 , chlorites in which $\mathrm{Mg}$ is the dominant bivalent octahedral cation, fall in the median part of the Si range, between Si 2.60 and 3.20 formula positions, and below the $\mathrm{Fe}^{+2}: \mathrm{R}^{+2} 0.10$ line.

The diagram at the top of figure 4 shows that the greatest density of points in the Si range is between 2.50 and 2.70. The 63 chlorites in which $\mathrm{Si}$ occupies between 2.50 and 2.70 positions range in $\mathrm{Fe}_{2}{ }^{+2}: \mathrm{R}^{+2}$ from 0.00 to 1.00 and represent a continuous and complete $\mathrm{Mg}$ replacement series. The greatest density of points in the $\mathrm{Fe}^{+2}: \mathrm{R}^{+2}$ range, as shown by the diagram on the right side of figure 4 , is between 0.00 and 0.10 . The 56 chlorites in which $\mathrm{Fe}^{+2}: \mathrm{R}^{+2}$ is 0.10 or less range in Si positions from 2.50 to 3.35 and represent an incomplete series in which $\mathrm{Si}$ and $\mathrm{R}^{+2}$ replace $R^{+3}$. Thus two principal types of replacement are found in the chlorites, and the composition of most chlorites can be largely interpreted in terms of one of these types of replacement or the other, or by a combination of the two.

\section{MAGNESIUM REPLACEMENT SERIES}

The chlorites represented by points in the most populated area in the Si range, between Si 2.50 and 2.70 , vary in the ratio of $\mathrm{Fe}^{+2}$ to $\mathrm{R}^{+2}$ from 0.00 to 1.00 , and demonstrate gradual replacement of $\mathrm{Mg}$ by $\mathrm{Fe}^{+2}$. The gradual transition in the chemical character of the chlorites in this Si range is shown by the average formulas in the following table, and by the diagrams of the octahedral groups of the average formulas shown in figure 5. The average formulas were calculated from an average of the analyses whose calculated formulas have Si 2.50 to 2.70 , and
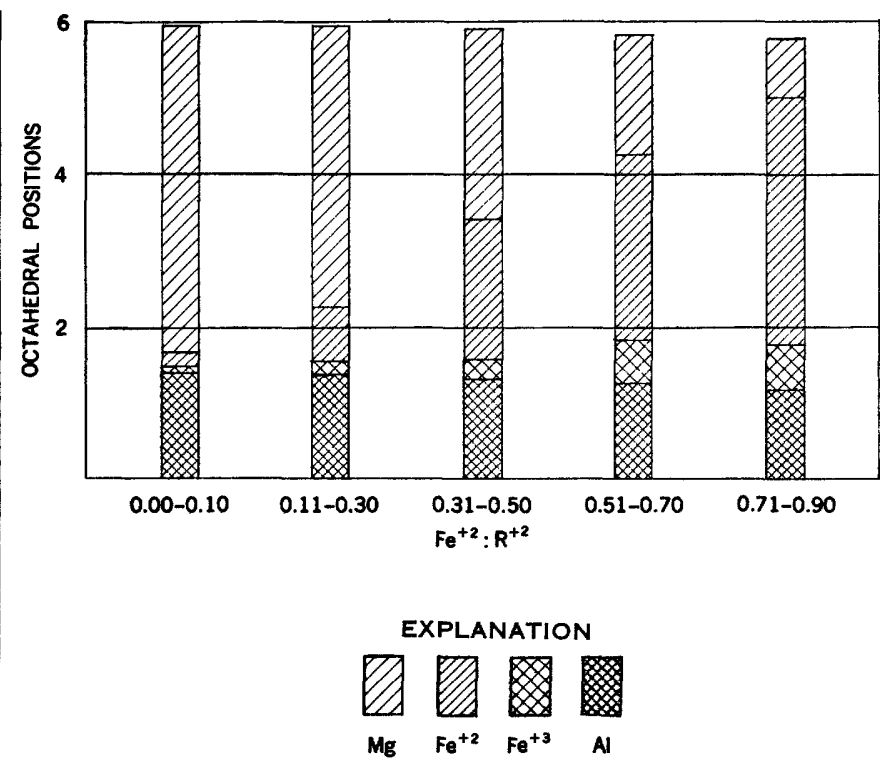

FIGURE 5.-Diagrams of octahedral groups of average formulas showing transition in character from highly magnesian to highly ferroan in the Si range 2.50-2.70.

the ratio of $\mathrm{Fe}^{+2}$ to $\mathrm{R}^{+2}$ is indicated. The diagrams represent graphically the octahedral content of the average formulas. Between the first formula, which has the composition of a very highly magnesian chlorite, and the last formula, which has the composition of a very highly ferroan chlorite, there is a gradual decrease in the number of positions occupied by $\mathrm{Mg}$, and a gradual increase in the number of positions occupied by $\mathrm{Fe}^{+2}$. This transition in character, characterized by decrease in $\mathrm{Mg}$ and increase in $\mathrm{Fe}^{+2}$, is similar to that in the trioctahedral micas (Foster, 1960); highly magnesian chlorites being analogous to phlogopites, intermediate chlorites being analogous to biotites, and highly ferroan chlorites being analogous to siderophyllites and lepidomelanes. $\mathrm{Mg}$ is replaced ion for ion by $\mathrm{Fe}^{+2}$ and, as both ions carry the same charge, no change in layer charge relations, in octahedral occupancy, or in tetrahedral content, is involved.

Average formulas showing transition in character from highly magnesian to highly ferroan (Si 2.50 - 2.70)

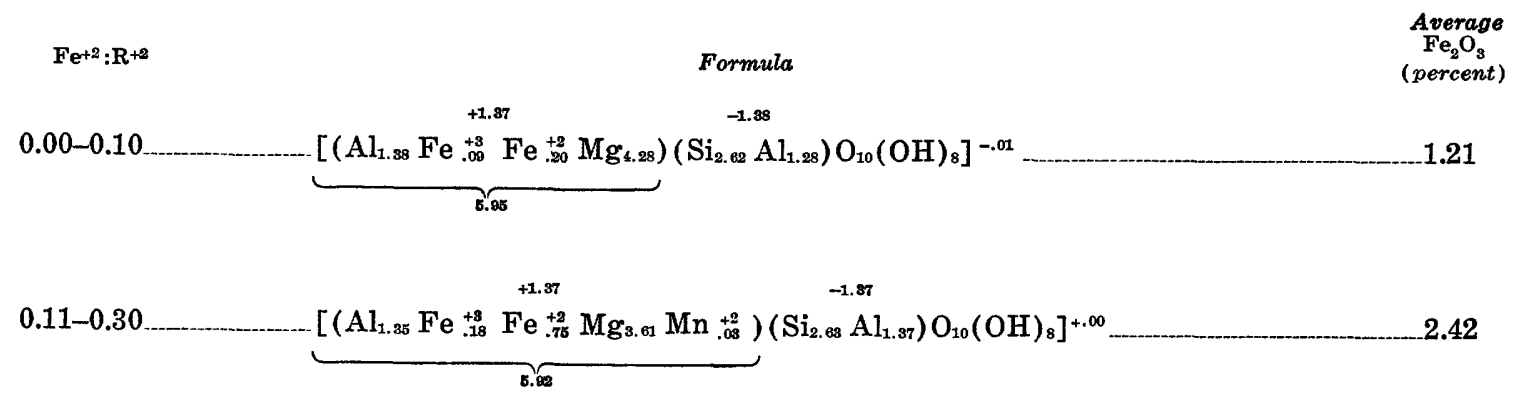




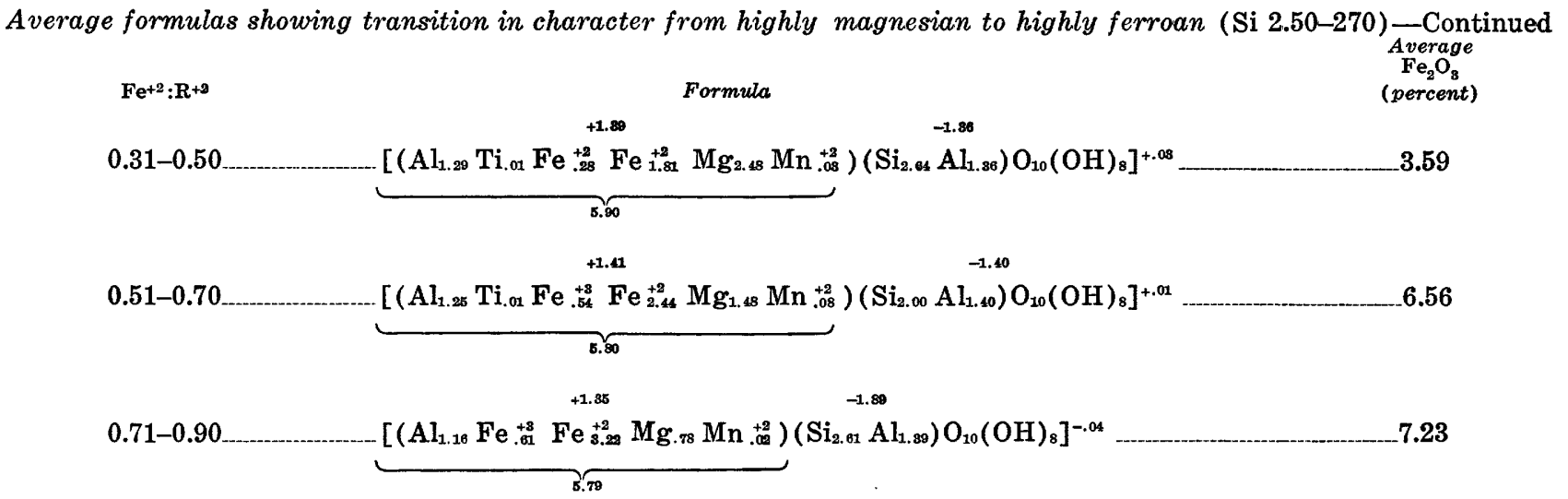

The average formulas indicate a general increase in $\mathrm{Fe}^{+3}$ concurrent with increase in $\mathrm{Fe}^{+2}$, from 0.09 positions in the first formula to 0.61 positions in the last formula. However, the amount of $\mathrm{Fe}_{2} \mathrm{O}_{3}$ in individual chlorites throughout the $\mathrm{Fe}^{+2}: \mathrm{R}^{+2}$ range varies greatly, and a given degree of replacement by $\mathrm{Fe}^{+2}$ has no relation to the degree of replacement by $\mathrm{Fe}^{+3}$. In chlorites in the 0.00 to $0.10 \mathrm{Fe}^{+2}: \mathrm{R}^{+2}$ range in which $\mathrm{Si}$ occupies 2.50 to 2.70 positions, $\mathrm{Fe}_{2} \mathrm{O}_{3}$ varies between 0.20 to 4.05 percent, and averages 1.21 ; in the 0.11 to 0.30 range $\mathrm{Fe}_{2} \mathrm{O}_{3}$ varies between 0.57 to 6.84 percent and averages 2.42 percent; in the 0.31 to 0.50 range $\mathrm{Fe}_{2} \mathrm{O}_{3}$ varies between 0.23 to 8.59 and averages 3.59 percent, with 5 out of 16 containing more than 4 percent; in the 0.51 to 0.70 range, $\mathrm{Fe}_{2} \mathrm{O}_{3}$ varies from none to 13.13 , and averages 6.56 percent, with 7 out of 11 containing more than 4 percent; in the 0.71 to 0.90 range $\mathrm{Fe}_{2} \mathrm{O}_{3}$ varies between 1.86 to 15.13 , and averages 7.23 percent, with 9 out of 11 containing more than 4 percent. The only analyses that produced a ratio of $\mathrm{Fe}^{+2}$ to $\mathrm{R}^{+2}$ greater than 0.90 contained 9 percent $\mathrm{Fe}_{2} \mathrm{O}_{3}$. Thus, although a chlorite in the lower part of the $\mathrm{Fe}^{+2}: \mathrm{R}^{+2}$ range may contain as much $\mathrm{Fe}_{2} \mathrm{O}_{3}$ as one in the upper part, the amount of $\mathrm{Fe}_{2} \mathrm{O}_{3}$ usually present increases with increase in the ratio of $\mathrm{Fe}^{+2}$ to $\mathrm{R}^{+2}$, and this is reflected in the average formulas. Even in chlorites having a ratio of $\mathrm{Fe}^{+2}$ to $\mathrm{R}^{+2}$ less than $0.10, \mathrm{Fe}_{2} \mathrm{O}_{3}$ averages more than 1 percent, and 16 of the 22 chlorites having a ratio of $\mathrm{Fe}^{+2}$ to $\mathrm{R}^{+2}$ greater than 0.50 in the Si 2.50 to 2.70 range contained more than 4 percent $\mathrm{Fe}_{2} \mathrm{O}_{3}$.

In the average formulas there is a slight progressive decrease in octahedral $\mathrm{Al}$ with increase in $\mathrm{Fe}^{+2}: \mathrm{R}^{+2}$ ratio. In the first formula octahedral $\mathrm{Al}$ is exactly equal to tetrahedral $\mathrm{Al}$, and thus furnishes the necessary number of positive charges to the octahedral layers to balance the negative tetrahedral charge. Consequently none of the $\mathrm{Fe}^{+3}$ present, 0.09 position, is necessary to supply additional positive charges. The deficiency in the total number of octahedral positions occupied indicates that $\mathrm{Fe}^{+3}$ can be interpreted as proxying for $\mathrm{R}^{+2}$ in a $2: 3$ ratio. In the subsequent average formulas octahedral $\mathrm{Al}$ is slightly but increasingly deficient, and some of the $\mathrm{Fe}^{+3}$ must be interpreted as proxying, 1:1, for $\mathrm{Al}$. In the fifth and last formula, octahedral $\mathrm{Al}$ is 0.23 position less than tetrahedral $\mathrm{Al}$, and approximately this much $\mathrm{Fe}^{+3}$ proxying for $\mathrm{Al}$ is needed for structural balance. The rest proxies for $R^{+2}$ in a $2: 3$ ratio, as indicated by the deficiency in octahedral occupancy.

Some individual formulas calculated from analyses that make up the averages are like the first average formula in having octahedral $\mathrm{Al}$ equivalent to tetrahedral $\mathrm{Al}$, and in which the $\mathrm{Fe}^{+3}$ present can be interpreted as replacing $R^{+2}$ in the $2: 3$ ratio, with octahedral occupancy deficient by an amount equivalent to about one-half the $\mathrm{Fe}^{+3}$. Other formulas are like the other average formulas, with some of the $\mathrm{Fe}^{+3}$ proxying for octahedral $\mathrm{Al}$, ion for ion, and the rest replacing $R^{+2}$ in the 2:3 ratio, and with octahedral deficiency equivalent to one-half the $\mathrm{Fe}^{+3}$ that replaces $R^{+2}$. Still other formulas have more octahedral $\mathrm{Al}$ than is necessary to neutralize the negative tetrahedral charge. Such formulas are also characterized by octahedral deficiency amounting to onehalf of the excess of octahedral $\mathrm{Al}$ over tetrahedral Al plus any $\mathrm{Fe}^{+3}$ present, indicating that the excess $\mathrm{R}^{+3}$ cations, $\mathrm{Al}$ or $\mathrm{Al}+\mathrm{Fe}^{+3}$, have replaced $\mathrm{R}^{+2} \mathrm{ca}-$ tions $2: 3$.

\section{Si AND $R^{+2}$ REPLACEMEN'T OF $\mathbf{R}^{+8}$}

The effects that accompany change in Si content are demonstrated by the chlorites represented by the points lying between the base line and the 0.10 $\mathrm{Fe}^{+2}: \mathrm{R}^{+2}$ line in figure 4 , in which $\mathrm{Si}$ varies from 2.50 to about 3.40 positions. These effects are shown by the average formulas in the following table, and by the diagrams of the average formulas in figure 6 . 
The average formulas are calculated from averages of the analyses whose calculated formulas have $\mathrm{Fe}^{+2}: \mathrm{R}^{+2} 0.10$ or less, excluding those containing $\mathrm{Cr}$. Theoretically increase in $\mathrm{Si}$ should be accompanied by an equivalent decrease in tetrahedral $\mathrm{Al}$, an equivalent decrease in octahedral $R^{+3}$ and an equivalent increase in octahedral $\mathrm{R}^{+2}$ in accordance with the following equation:

$$
\mathrm{Si}^{+4}+\mathrm{R}^{+2}=\mathrm{R}^{+8}(\mathrm{IV})+\mathrm{R}^{+8}(\mathrm{VI}) \text {. }
$$

Inspection of the average formulas shows that between the first and last there is an increase of 0.57 in $\mathrm{Si}$ positions, an increase of 0.49 in $\mathrm{R}^{+2}$ (dominantly $\mathrm{Mg}$ ) positions, a decrease in 0.57 in tetrahedral Al positions, and a decrease of 0.52 in octahedral $\mathrm{R}^{+3}$ (dominantly $\mathrm{Al}$ ) positions. These changes in composition are in good accordance with the theoretical equation. Continued increase in $\mathrm{Si}$ and $\mathrm{Mg}$ and decrease in tetrahedral and octahedral $R^{+3}$ would result in a neutral tetrahedral group completely occupied by Si and a neutral octahedral group completely occupied by $\mathrm{Mg}, \mathrm{Mg}_{6.00} \mathrm{Si}_{4.00} \mathrm{O}_{10}(\mathrm{OH})_{8}$.

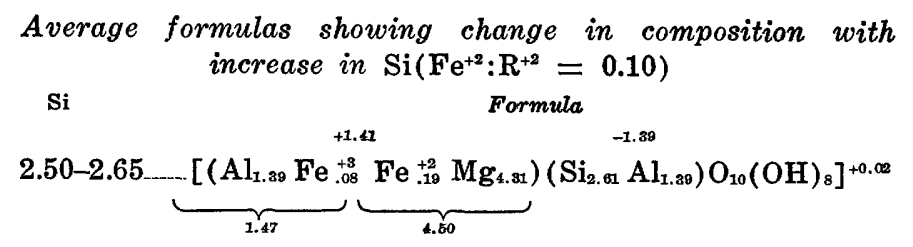

$$
\begin{aligned}
& 2.66-2.80+1.23 \quad-1.25 \\
& {\left[\left(\mathrm{Al}_{1.21} \mathrm{Fe}_{.12}^{+2} \mathrm{Fe}_{.20}^{+2} \mathrm{Mg}_{4.41} \mathrm{Mn}_{.01}^{+2}\right)\left(\mathrm{Si}_{2.75} \mathrm{Al}_{1.25}\right) \mathrm{O}_{10}(\mathrm{OH})_{8}\right]^{-0.02}} \\
& \underbrace{}_{1.33} \underbrace{.02}_{4.02}
\end{aligned}
$$$$
2.81-2.95 \underbrace{\left[\left(\mathrm{Al}_{.80} \mathrm{Fe}_{.12}^{+1.00}\right.\right.}_{1.11} \underbrace{\left.\mathrm{Fe}{ }_{.16}^{+2} \mathrm{Mg}_{4.72}\right)}_{4.88}\left(\mathrm{Si}_{2.89}^{-1.10} \mathrm{Al}_{1.10}\right) \mathrm{O}_{10}(\mathrm{OH})_{8}]^{-0.1}
$$$$
2.96-3.10 \underbrace{\left[\left(\mathrm{Al}_{.87} \mathrm{Fe}{ }_{.12}^{+.92}\right.\right.}_{.80} \underbrace{\left.\mathrm{Fe} e_{.24}^{+2} \mathrm{Mg}_{4.75}\right)}_{4.89}\left(\mathrm{Si}_{2.03}^{-.07} \mathrm{Al}_{.87}\right) \mathrm{O}_{10}(\mathrm{OH})_{8}]^{-0.02}
$$$$
3.11-3.25 \ldots \underbrace{\left[\left(\mathrm{Al}_{.78} \mathrm{Fe}{ }_{.17}^{+2}\right.\right.}_{. .5} \underbrace{\mathrm{Fe}_{.25}^{+2} \mathrm{Mg}_{4.74}}_{4.89})\left(\mathrm{Si}_{3.18}^{-.82} \mathrm{Al}_{.82}\right) \mathrm{O}_{10}(\mathrm{OH})_{8}]^{+0.02}
$$

In three of the average formulas, the first, second, and fifth, octahedral $\mathrm{Al}$ is about equivalent to tetrahedral $\mathrm{Al}$, and most of the $\mathrm{Fe}^{+3}$ present proxies, 2 to 3 , for $\mathrm{R}^{+2}$, and octahedral occupancy is, consequently, slightly deficient in these formulas. In the third and fourth formulas, on the other hand, octahedral $\mathrm{Al}$ is about 0.10 position less than tetrahedral $\mathrm{Al}$, and all or most of the $\mathrm{Fe}^{+3}$ is necessary to give the octahedral layers enough positive charge for structural neutrality.
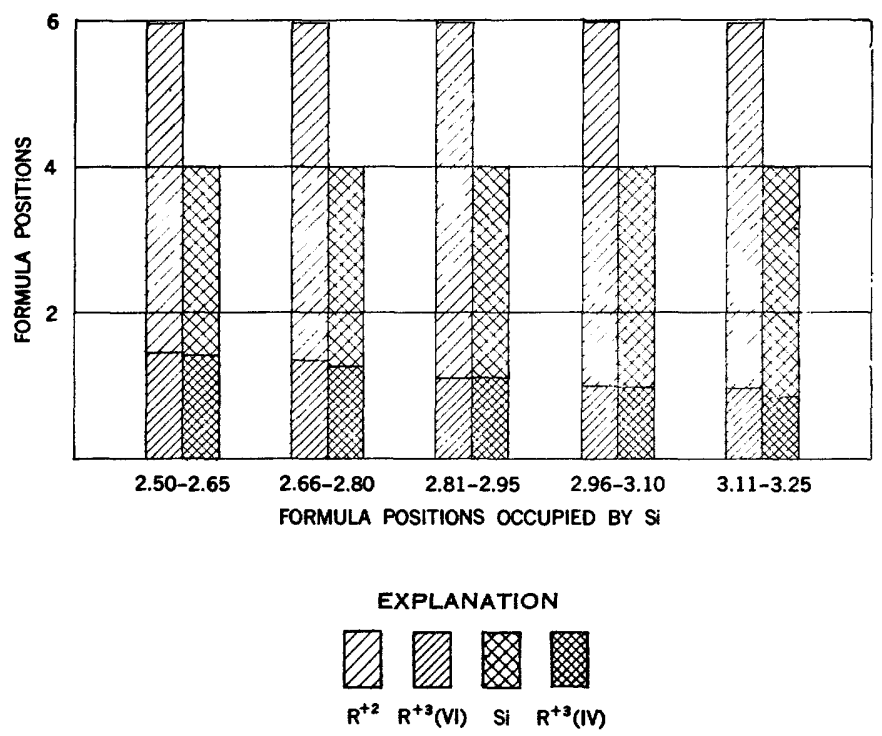

Fraurs 6.-Diagrams of average formulas showing change in composition of chlorites having a $\mathrm{Fe}^{+2}: \mathrm{R}^{+2}$ ratio of less than 0.10 with increase in $\mathrm{Si}$ content.

These two types of ionic replacement, replacement of $\mathrm{Mg}$ by $\mathrm{Fe}^{+2}$ and replacement of tetrahedral and octahedral $R^{+3}$ by $\mathrm{Si}$ and $\mathrm{Mg}$, serve to interpret the composition of most chlorites. In some, as in the chlorites represented by points to the left of the $\mathrm{Si}$ 2.80 line in figure 4, replacement of $\mathrm{Mg}$ by $\mathrm{Fe}^{+2}$ is predominant. In others, as in the chlorites represented by points along the base line and below the $\mathrm{Fe}^{+2}: \mathrm{R}^{+2} 0.10$ line, replacement of tetrahedral $\mathrm{Al}$ and octahedral $R^{+3}$ by $\mathrm{Si}$ and $\mathrm{Mg}$ is predominant. In still others, as in chlorites to the right of the Si 2.80 line, and above the $\mathrm{FE}^{+2}: \mathrm{R}^{+2} 0.10$ line, both types of replacement are shown in some degree. Chlorites represented by points between Si 2.50 and 2.70 in figure 4 constitute a complete $\mathrm{Mg}$ replacement series, from wholly magnesian, with respect to $R^{+2}$ cations, to wholly ferroan, whereas chlorites represented by points on or below the $0.10 \mathrm{Fe}^{+2}: \mathrm{R}^{+2}$ line constitute an incomplete $\mathrm{Si}-\mathrm{Mg}$ replacement series about half way between $\mathrm{Mg}_{4} \mathrm{Al}_{4} \mathrm{Si}_{2} \mathrm{O}_{10}(\mathrm{OH})_{8}$, amesite, and $\mathrm{Mg}_{6} \mathrm{Si}_{4} \mathrm{O}_{10}(\mathrm{OH})_{8}$, antigorite.

In addition to these two principal types of replacement in the chlorites, there is also some replacement of octahedral $\mathrm{Al}$ and (or) $\mathrm{R}^{+2}$ by $\mathrm{Fe}^{+3}$, and replacement of $\mathrm{R}^{+2}$ by $\mathrm{Al}$. These replacements are relatively more important in the ferroan chlorites than in the magnesian chlorites.

\section{$\mathrm{Fe}^{+3}$ REPLACEMENT OF AI AND $\mathbf{R}^{+2}$}

Octahedral $\mathrm{Al}$ was less than tetrahedral $\mathrm{Al}$ in almost two-thirds of the chlorite formulas studied. In such formulas, some other trivalent ion, usually $\mathrm{Fe}^{+3}$, must contribute to the positive charge on the octahedral group to increase it sufficiently to balance 
the negative tetrahedral charge. Among the formulas studied almost two-thirds were deficient in octahedral $\mathrm{Al}$ as compared with tetrahedral $\mathrm{Al}$ and some or all of the $\mathrm{Fe}^{+3}$ present is required for structural balance. In most of the highly magnesian chlorites $\left(\mathrm{Fe}^{+2}: \mathrm{R}^{+2}<0.25\right)$ that are deficient in octahedral $\mathrm{Al}$, all the $\mathrm{Fe}^{+3}$ present is necessary to raise the octahedral charge sufficiently for structural balance, but in most of the chlorites with higher $\mathrm{Fe}^{+2}: \mathrm{R}^{+2}$ ratio only part of the $\mathrm{Fe}^{+3}$ present is so needed. $\mathrm{Fe}^{+3}$ that contributes to the positive octahedral charge is interpreted as proxying for octahedral $\mathrm{Al}$, ion for ion.

Some chlorites contain more trivalent ions, $\mathrm{Al}$ and (or) $\mathrm{Fe}^{+3}$, and sometimes $\mathrm{Cr}^{+3}$, than are needed to balance the negative tetrahedral charge. Formulas for such chlorites are characterized not only by an excess of octahedral $R^{+3}$ cations, but also by deficiency in the total number of positions occupied which is approximately equal to one-half the number of excess trivalent octahedral cations. This deficiency indicates that the excess $R^{+3}$ cations are proxying for $\mathrm{R}^{+2}$ cations in a ratio of 2 to 3 .

\section{STATUS OF $\mathrm{Fe}_{2} \mathrm{O}_{3}$ IN CHLORITES}

Winchell $(1926,1928,1936)$ and later Holzner (1938) regarded $\mathrm{Fe}_{2} \mathrm{O}_{3}$ in chlorites as the result of secondary oxidation of $\mathrm{FeO}$, because they were able to reduce many leptochlorites to orthochlorite composition by representing all the $\mathrm{Fe}_{2} \mathrm{O}_{3}$ as $\mathrm{FeO}$. Dschang (1931) and others showed that high ferrous orthochlorites can be oxidized by careful heating in air without change in crystal structure and are then similar in physical properties to high ferric leptochlorites. However, Hallimond (1939) believed that at least part of the $\mathrm{Fe}_{2} \mathrm{O}_{3}$ may be really a normal constituent of chlorites. More recently Hey (1954) proposed that the arbitrary figure of 4 percent $\mathrm{Fe}_{2} \mathrm{O}_{3}$ be taken as the dividing line between unoxidized and oxidized chlorites and classified chlorites into two groups on this basis. Thus there has been some disagreement as to the status of $\mathrm{Fe}_{2} \mathrm{O}_{3}$ in chlorites, with a tendency to regard it an abnormal constituent.

Structural balance in chlorites requires that the octahedral layers have a positive charge equivalent to the negative tetrahedral charge. To have such a positive charge, the octahedral layers must contain a certain minimum of trivalent cations, and if the $\mathrm{Al}$ is low, the difference must be made up by other trivalent octahedral cations, such as and usually $\mathrm{Fe}^{+3}$. In the discussion of the relation between tetrahedral and octahedral $\mathrm{Al}$ (p. A-7) and in figure 2 it was shown that many chlorites do not contain as much octahedral $\mathrm{Al}$ as tetrahedral $\mathrm{Al}$. In some of these chlorites all the $\mathrm{Fe}^{+3}$ cations present are necessary to give the octahedral layer a positive charge equivalent to the negative tetrahedral charge. This relation is illustrated in the following formulas calculated from analyses 84 and 136, table 2, which contain 5.26 and 8.70 percent $\mathrm{Fe}_{2} \mathrm{O}_{3}$, respectively.

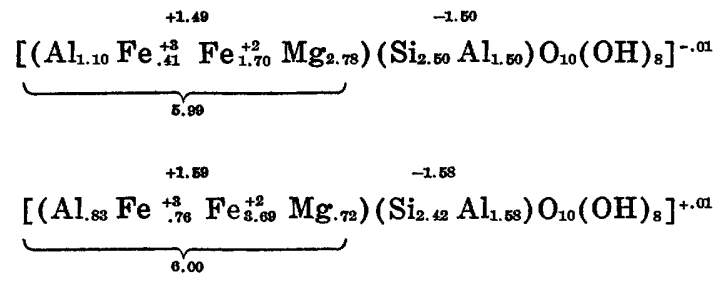

In these formulas, in which all the octahedral trivalent cations present are just sufficient to produce structural balance, all the octahedral positions are occupied, $\mathrm{Fe}^{+3}$ proxies for $\mathrm{Al}$, and there is no replacement of $R^{+2}$ cations by $R^{+3}$ cations. In other chlorites part of the $\mathrm{Fe}^{+3}$ is required for structural balance, the amount required sometimes exceeding Hey's arbitrary value of 4 percent, as in the following formulas for analyses 135 and 144, table 2, which contain 10.15 and 11.98 percent $\mathrm{Fe}_{2} \mathrm{O}_{3}$, respectively,

$$
\begin{aligned}
& \underbrace{\left[\left(\mathrm{Al}_{1.02} \mathrm{Fe}_{.87}^{+3} \mathrm{Fe}_{8.28}^{+2.08} \mathrm{Mg} .61_{.61} \mathrm{Mn}_{.08}^{+2}\right)\right.}_{5.87}\left(\mathrm{Si}_{2.84} \mathrm{Al}_{1.66}\right) \mathrm{O}_{10}(\mathrm{OH})_{8}]^{-.08} \\
& \underbrace{\left[\left(\mathrm{Al}_{.58} \mathrm{Ti}_{.02}^{+1.41} \mathrm{Fe}_{1.05}^{+3} \mathrm{Fe}_{8.66}^{+2}\right.\right.}_{5.88} \mathrm{Mg} . .50)\left(\mathrm{Si}_{2.61}^{-1.30} \mathrm{Al}_{1.39}\right) \mathrm{O}_{10}(\mathrm{OH})_{8}]^{+.02}
\end{aligned}
$$

In the formula for analysis $135,0.61 \mathrm{Fe}^{+3}$ proxies for octahedral $\mathrm{Al}$ in a ratio of $1: 1$, and 0.26 for $\mathrm{R}^{+2}$ in a ratio of $2: 3$, and octahedral occupancy is deficient by 0.13 position. In the formula for analysis 144 , $0.02 \mathrm{Ti}$ and $0.81 \mathrm{Fe}^{+3}$ proxy for octahedral $\mathrm{Al}$ in a 1:1 ratio, $0.24 \mathrm{Fe}^{+3}$ proxy for $\mathrm{R}^{+2}$ in a $2: 3$ ratio, and octahedral occupancy is deficient by 0.12 position. In both formulas more than two-thirds of the trivalent iron present is essential for structural balance.

If all the $\mathrm{Fe}_{2} \mathrm{O}_{3}$ is reduced to $\mathrm{FeO}$ in the four analyses cited above, and the formulas recalculated, the formulas resulting have sufficient octahedral charge to balance the tetrahedral charge because of the excessive number of bivalent cations present, and considerably more than 6.00 octahedral positions are occupied :

analysis 84 ,

$$
\underbrace{\left[\left(\mathrm{Al}_{1.18}^{+1.46} \mathrm{Fe}_{2.14}^{+2} \mathrm{Mg}_{2.82}\right)\right.}_{6.14}\left(\mathrm{Si}_{2.54}^{-1.48} \mathrm{Al}_{1.48}\right) \mathrm{O}_{10}(\mathrm{OH})_{8}]^{.00}
$$


analysis 136 ,

$$
\underbrace{\left[\left(\mathrm{Al}_{.07} \mathrm{Fe}_{4.68}^{+1.51} \mathrm{Mg}_{.74}\right.\right.}_{6.27})\left(\mathrm{Si}_{2.48}^{-1.51} \mathrm{Al}_{1.51}\right) \mathrm{O}_{10}(\mathrm{OH})_{8}]^{.00}
$$

analysis 135 ,

$$
\underbrace{\left[\left(\mathrm{Al}_{1.18} \mathrm{Fe}{ }_{4.80}^{+2} \mathrm{Mg}_{.68}^{+1.59} \mathrm{Mn}_{.08}^{+2}\right)\right.}_{6.20}\left(\mathrm{Si}_{2.42}^{-1.59} \mathrm{Al}_{1.68}\right) \mathrm{O}_{10}(\mathrm{OH})_{8}]^{+.01}
$$

analysis 144,

$$
\underbrace{\left[\left(\mathrm{Al}_{.74} \mathrm{Ti}_{.02}^{+.180} \mathrm{Fe}_{4.88}^{+2} \mathrm{Mg}_{.82}\right)\right.}_{0.28}\left(\mathrm{Si}_{2.71}^{-1.28} \mathrm{Al}_{1.28}\right) \mathrm{O}_{10}(\mathrm{OH})_{8}]^{+.01}
$$

As the chlorite structure provides only 6.00 positions for octahedral cations, reduction of $\mathrm{Fe}^{+3}$ to $\mathrm{Fe}^{+2}$ yields irrational and unacceptable formulas for these analyses.

Even the presence of $\mathrm{Fe}^{+3}$ cations not needed for structural balance is not necessarily evidence for secondary oxidation. The fact that many chlorites contain more octahedral $\mathrm{Al}$ than is required to balance the negative tetrahedral charge indicates that the chlorite structure can accommodate an excess of trivalent octahedral cations. In these chlorites, octahedral $\mathrm{Al}$ in excess of tetrahedral $\mathrm{Al}$ replaces $\mathrm{R}^{+2}$ in the ratio of 2 to 3 , and octahedral occupancy is less than 6.00 by an amount equivalent to one-half the number of excess $\mathrm{Al}$ cations. $\mathrm{Fe}^{+3}$ cations not needed for structural balance can be accommodated in a similar manner. Figure 3 shows that the same accommodation of excess trivalent octahedral cations is found whether the excess be made up entirely of $\mathrm{Al}$, entirely of $\mathrm{Fe}^{+3}$, or both.

The relation between $\mathrm{Fe}^{+2}: \mathrm{R}^{+2}$ ratio and $\mathrm{Fe}_{2} \mathrm{O}_{3}$ content in the chlorites studies is shown in figure 7. Few chlorites in which the $\mathrm{Fe}^{+2}: \mathrm{R}^{+2}$ ratio is less than 0.45 contain more than 4 percent $\mathrm{Fe}_{2} \mathrm{O}_{3}$, only 10 out of 90 , whereas two-thirds of the chlorites in which $\mathrm{Fe}^{+2}: \mathrm{R}^{+2}$ is 0.45 or more contain more than 4 percent $\mathrm{Fe}_{2} \mathrm{O}_{3}$. It seems improbable that such a large proportion of the ferrous chlorites that have been analyzed and studied should have undergone secondary oxidation. Many chlorites occur as secondary minerals resulting from the alteration of other species, such as olivine, pyroxene, amphibole, biotite, garnet, and idocrase, some of which contain $\mathrm{Fe}_{2} \mathrm{O}_{3}$, and it is to be expected that chlorites derived from such sources should incorporate $\mathrm{Fe}^{+3}$ ions in their structures. The mere presence of $\mathrm{Fe}_{2} \mathrm{O}_{3}$, or its presence in excess of some specified amount, should not be arbitrarily attributed, therefore, to secondary oxidation. $\mathrm{Fe}^{+3}$ should be considered a normal constituent of chlorites, as it is considered a normal constituent of other layer silicates, such as biotites, unless other criteria indicate the probability of oxidation.

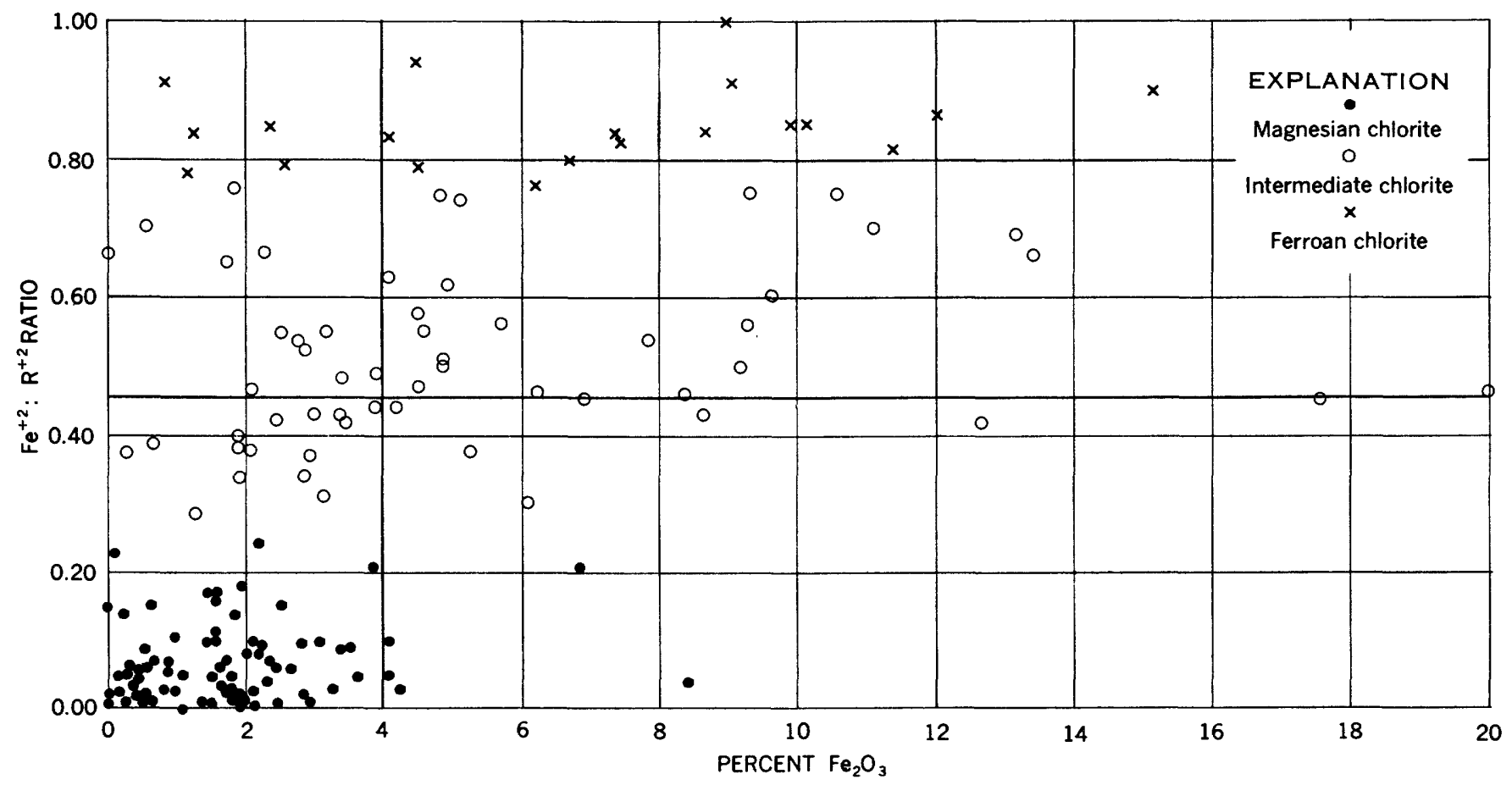

FugURE 7.-Diagram showing relation between $\mathrm{Fe}^{+2}: \mathrm{R}+2$ ratio and $\mathrm{Fe}_{2} \mathrm{O}_{8}$ in chlorites. 


\section{CLASSIFICATION OF CHLORITES}

\section{SOME PREVIOUS CLASSIFICATIONS}

Tschermak $(1890,1891)$ divided the chlorites into two groups, the orthoclorites, which varied in composition between $\left(\mathrm{Mg}, \mathrm{Fe}^{+2}\right)_{2} \mathrm{Al}_{2} \mathrm{SiO}_{5}(\mathrm{OH})_{4}$ and $\left(\mathrm{Mg}, \mathrm{Fe}^{+2}\right)_{3} \mathrm{Si}_{2} \mathrm{O}_{5}(\mathrm{OH})_{4}$, and the leptochlorites, which were relatively higher in trivalent cation and lower in bivalent cation content and fell to the left of a line joining the above end members. Winchell (1926, 1936) pointed out that many leptochlorites contained considerable trivalent iron and that recomputation of the trivalent iron as bivalent iron placed them among the orthochlorites. Hey (1954) divided the chlorites into two series, an "unoxidized normal" series, and an "oxidized" series, with an arbitrary figure of 4 percent $\mathrm{Fe}_{2} \mathrm{O}_{3}$ taken as the dividing line between "unoxidized" and "oxidized" chlorites. Hey subdivided the chlorites in the unoxidized series into 11 species and 4 varieties depending on the number of $\mathrm{Si}$ atoms in the half-cell and the $\mathrm{Fe}:(\mathrm{Fe}+\mathrm{Mg})$ ratio. Hey does not state the basis upon which he fixed the boundaries between these species and varieties. He divided the chlorites in the oxidized series into three species, based only on Si content, with only one of these species, thuringite, being subdivided with respect to $\mathrm{Fe}:(\mathrm{Fe}+\mathrm{Mg})$ ratio, thuringites with $\mathrm{Fe}:(\mathrm{Fe}+\mathrm{Mg})$ ratio less than 0.5 being classed as a variety of thuringite, klementite.

The effect of this arbitrary division of chlorites into two groups on the basis of $\mathrm{Fe}_{2} \mathrm{O}_{3}$ content is shown in figure 8 , in which the chlorites used in this study are plotted according to Hey's scheme, chlorites containing less than 4 percent $\mathrm{Fe}_{2} \mathrm{O}_{3}$ being plotted in graph $\mathrm{A}$, and chlorites containing more than 4 percent $\mathrm{Fe}_{2} \mathrm{O}_{3}$ being plotted in graph $\mathrm{B}$. Of the chlorites used in the present study, only six with $\mathrm{Fe}:(\mathrm{Fe}+\mathrm{Mg})$ ratios greater than 0.5 and with $\mathrm{Si}$ less than 2.80 have less than 4 percent $\mathrm{Fe}_{2} \mathrm{O}_{3}$. All fall in the ripidolite or ripidolite-aphrosiderite area, none fall in the pseudothuringite, daphnite, or daphnite-bavalite areas. All the other chlorites (29) with $\mathrm{Fe}:(\mathrm{Fe}+\mathrm{Mg})$ ratios greater than 0.50 and $\mathrm{Si}$ less than 2.80 have more than 4 percent $\mathrm{Fe}_{2} \mathrm{O}_{3}$ and fall in the large, undifferentiated thuringite area. As most ferrous chlorites contain more than 4 percent $\mathrm{Fe}_{2} \mathrm{O}_{3}$ and have less than 2.80 tetrahedral positions occupied by $\mathrm{Si}$, Hey's scheme leaves the great majority of ferrous chlorites undifferentiated, but provides several categories for the classification of the small minority that contain less than 4 percent $\mathrm{Fe}_{2} \mathrm{O}_{3}$.

Hey's arbitrary dividing line of 4 percent $\mathrm{Fe}_{2} \mathrm{O}_{3}$ between unoxidized and oxidized chlorites would classify the formula for analysis 20 , table 2 ,

$$
\left.[\underbrace{\left(\mathrm{Al}_{1.34} \mathrm{Fe}_{.20}^{+3} \mathrm{Fe}{ }_{.41}^{+2} \mathrm{Mgg}_{3.79}\right.}_{5.88})\left(\mathrm{Si}_{2.68}^{-1.82} \mathrm{Al}_{1.82}\right) \mathrm{O}_{10}(\mathrm{OH})_{8}\right]^{-0.03}
$$

as that of a thuringite, variety klementite, and the formula for analysis 22 , table 2 ,

$$
\underbrace{\left[\left(\mathrm{Al}_{1.48} \mathrm{Fe}_{.28}^{+8} \mathrm{Fe}_{.85}^{+2} \mathrm{Mg}_{3.02} \mathrm{Mn}_{.15}^{+2}\right.\right.}_{6.78})\left(\mathrm{Si}_{2.68}^{-1.32} \mathrm{Al}_{1.32}\right) \mathrm{O}_{10}(\mathrm{OH})_{8}]^{0.00}
$$

as that of a sheridanite, variety grochauite, merely because one contains 0.20 percent more $\mathrm{Fe}_{2} \mathrm{O}_{3}$ (equivalent to 0.01 formula position). Furthermore, in his classification, no discrimination is made between chlorites in which $\mathrm{Fe}^{+3}$ is required for structural balance, and those in which $\mathrm{Fe}^{+3}$ is not required for structural balance.

\section{CLASSIFICATION BASED ON IONIC REPLACEMENTS}

Many different names have been given to the chlorites, principally because of differences in chemical composition. As it is now known that differences in chemical composition in the chlorites are attributable to ionic replacements within the same structural framework, many of these names have become superfluous. In a group of minerals characterized by ionic replacements special names should apply to definite, delimited, and continuous parts of the series, and not to specific points. In the trioctahedral micas, for example, which are characterized principally by replacement of $\mathrm{Mg}$ by $\mathrm{Fe}^{+2}$, the term phlogopite refers to the magnesian end of the series, biotite to the middle of the series, and siderophyllite or lepidomelane to the ferrous end of the series. ${ }^{1}$ The chlorites, which are characterized principally by replacement not only of $\mathrm{Mg}$ by $\mathrm{Fe}^{+2}$, but also of $\mathrm{Al}$ by $\mathrm{Si}$ and $\mathrm{Mg}$, should be classified with respect to both replacement series. Such a scheme of classification is illustrated in figure 9, which is similar to figure 4 , in that the co-ordinates represent the number of positions occupied by $\mathrm{Si}$ and the $\mathrm{Fe}^{+2}: \mathbf{R}^{+2}$ ratio, as calculated from the number of positions occupied by $\mathrm{Fe}^{+2}$ and $\mathrm{R}^{+2}$ in the half-cell formula. Divisions with respect to $\mathrm{Fe}^{+2}: \mathrm{R}^{+2}$ ratio are drawn at 0.25 and 0.75 , making three categories, the magnesian chlorites, in which $\mathrm{Mg}$ makes up more than 75 percent of the bivalent cations; the intermediate chlorites, in which $\mathrm{Mg}$ makes up from 75 to 25 percent, and $\mathrm{Fe}^{+2}$ from 25 to 75 percent of the bivalent cations;

1 Annite, the ferrous analogue of phlogopite, apparently does not occur in nature because replacement of $\mathrm{Mg}$ by $\mathrm{Fe}^{+2}$ is always accompanied by some replace of $\mathrm{Mg}$ by $\mathrm{Al}$ or $\mathrm{Fe}^{+3}$. 


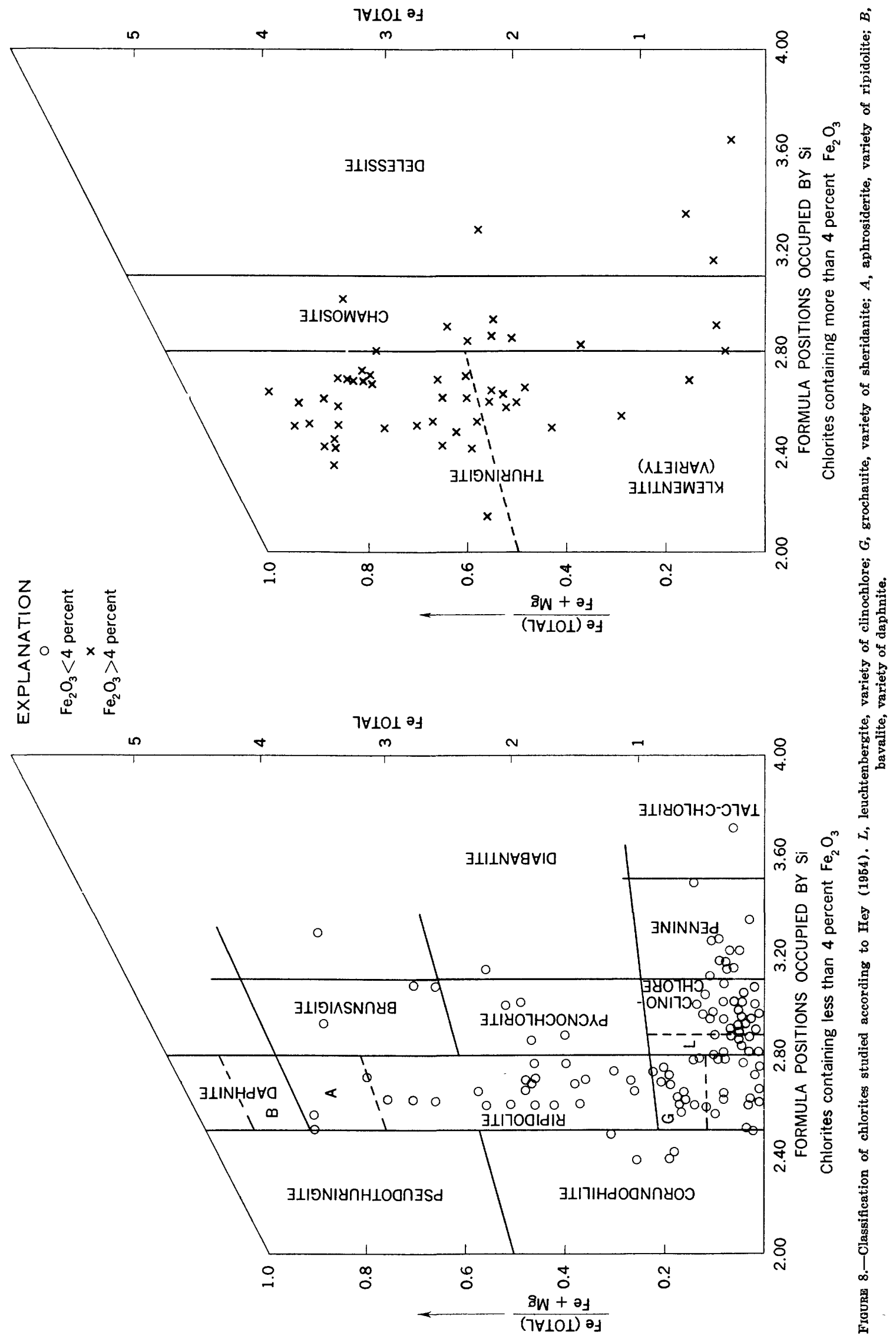




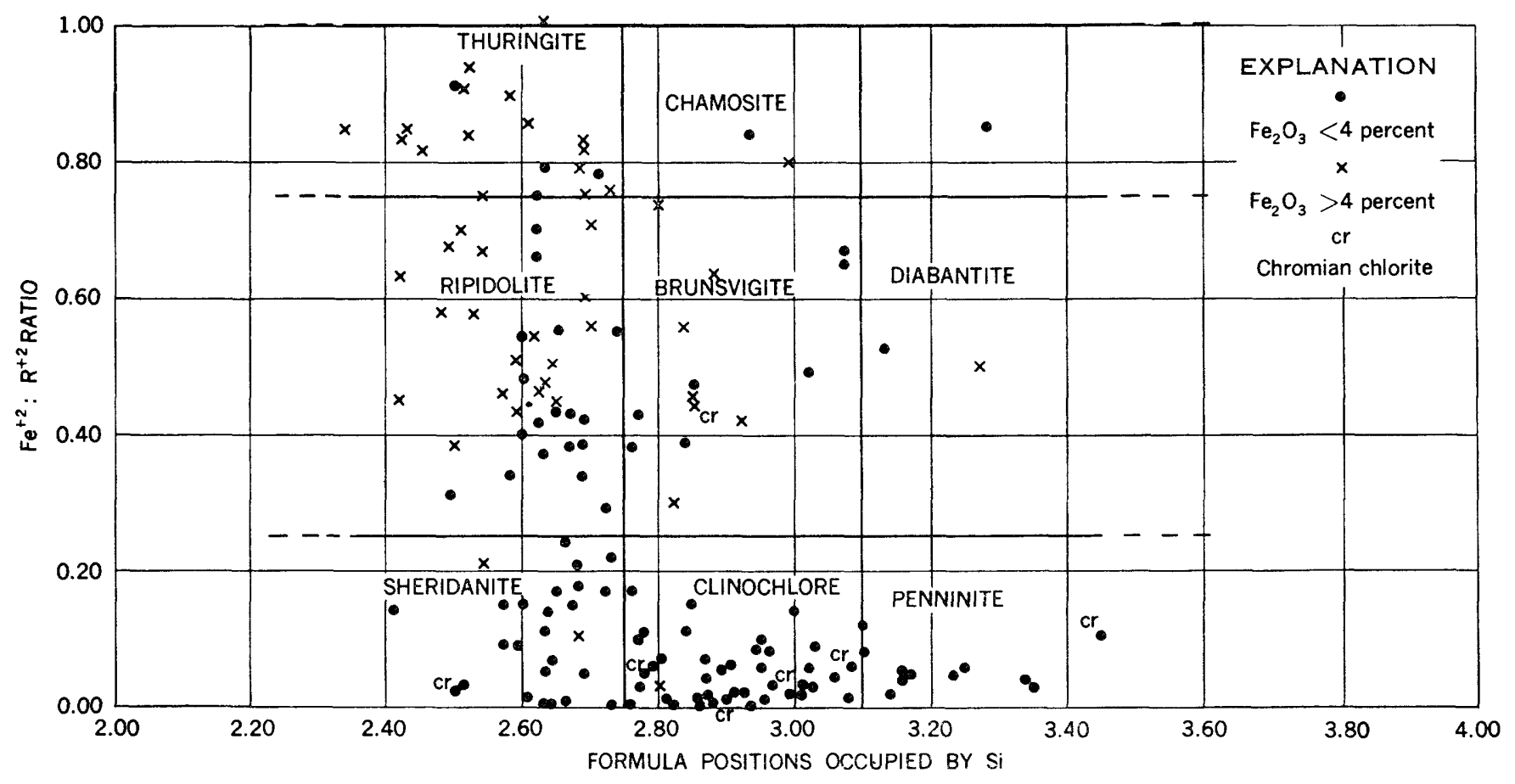

FIGURE 9.-Classification of chlorites based on the two principal types of ionic replacement.

and the ferroan chlorites, in which $\mathrm{Fe}^{+2}$ makes up more than 75 percent of the bivalent cations. These three categories are then subdivided with respect to Si content. The analyses used in this study indicate that chlorites seldom contain less than $2.35 \mathrm{Si}$ or more than $3.45 \mathrm{Si}$. Within this range of 1.10 formula positions between the extremes, the divisions are drawn at 2.75 and 3.10 , forming 3 fairly equal divisions with respect to $\mathrm{Si}$ content. Thus 9 areas, strictly defined with respect to $\mathrm{Fe}^{+2}: \mathrm{R}^{+2}$ ratio and Si content, are provided for the classification of chlorites.

The distribution of points in figure 9 shows that most of the chlorites studied fall into 5 of the 9 areas, a sixth area is fairly well populated, but the other 3 together contain only 5 points.

The variety of names given to the analyzed chlorites that fall in the different areas is shown in the following chart. Of the 26 chlorites falling in the area bounded by $\mathrm{Fe}^{+2}: \mathrm{R}^{+2} 0.00-0.25$ and Si 2.40-2.75, 22 were designated by 8 different names, and 4 were called simply chlorite; of the 43 chlorites falling in the area bounded by $\mathrm{Fe}^{+2}: \mathrm{R}^{+2} \quad 0.00-0.25$ and $\mathrm{Si} 2.75$ 3.1.0, 34 were designated by 6 different names, and 9 were called chlorite; and 8 of the 14 chlorites falling in the area bounded by $\mathrm{Fe}^{+2}: \mathrm{R}^{+2} 0.26-0.75$ and $\mathrm{Si}$ 2.76-3.10 were designated by 7 different names, with the other 6 being called chlorites. Not only were the chlorites falling in the more populous areas desig-

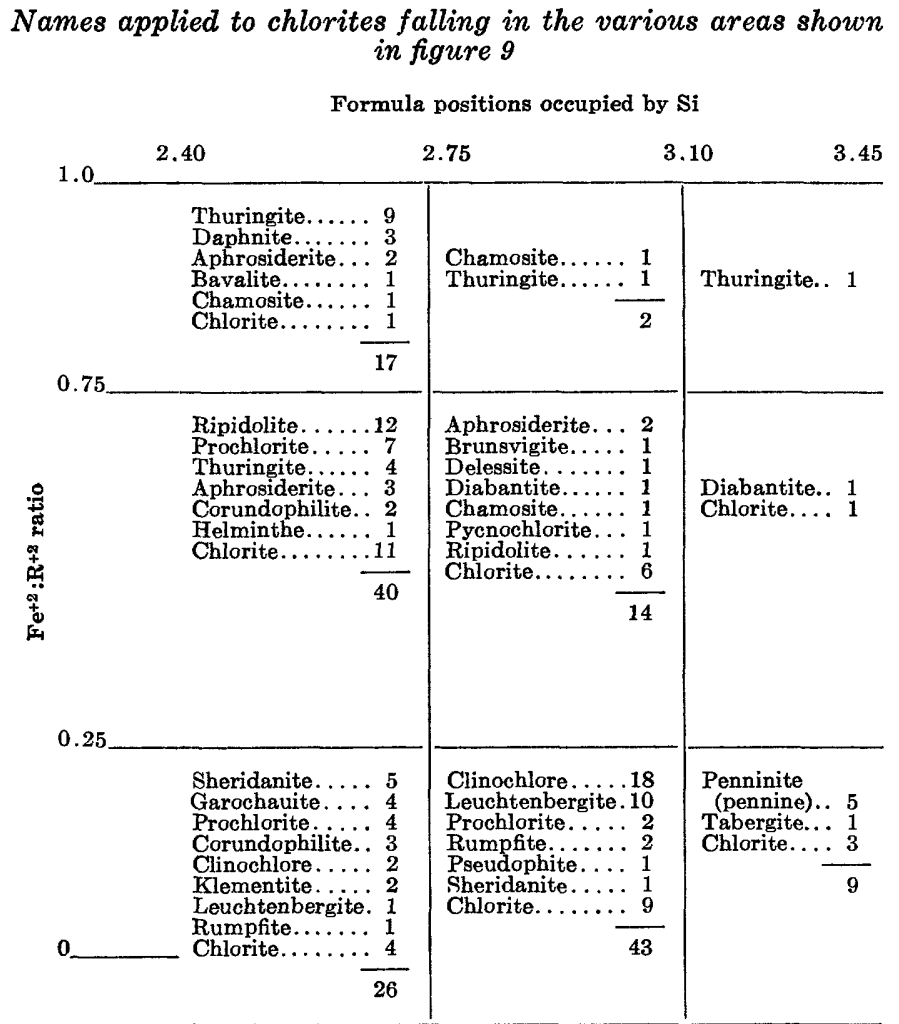

nated by a number of different names, but the same name may appear in more than one area. Corundophilite, ripidolite, rumpfite, leuchtenbergite, sheridanite, diabantite, and clinochlore appear in 2 areas, 
chamosite and aphrosiderite in 3 areas, and thuringite in 4 areas. Thus there seems to be considerable uncertainty among mineralogists with respect to definition and delimitation of species and varieties in the chlorites.

In the classification herein proposed, species occupy areas delimited by $\mathrm{Fe}^{+2}: \mathrm{R}^{+2}$ ratios and $\mathrm{Si}$ ranges, and the name chosen for a given species is based on usage as far as possible. For example, the area bounded by $\mathrm{Fe}^{+2}: \mathrm{R}^{+2}$ ratio $0.00-0.25$ and $\mathrm{Si} 2.76$ 3.10 (see fig. 9) is called the clinochlore area, as about half the chlorites falling in that area were called clinochlores by the authors of the papers in which the analyses were published. Similarly about half the chlorites falling in the area bounded by $\mathrm{Fe}^{+2}: \mathrm{R}^{+2}$ ratio $0.00-0.25$ and $\mathrm{Si}>3.10$ were called pennines or penninites, and so this area is called the penninite area. The areas assigned to these two species correspond with the areas assigned to them by Hey (1954) in Si ranges and in the highly magnesian character of the chlorites falling in them. Most of the analyses listed by Dana (1892) under clinochlore and penninite fall in these respective clinochlore and penninite areas. The use of no one name predominates greatly over several others for chlorites falling in the area bounded by $\mathrm{Fe}^{+2}: \mathrm{R}^{+2}$ ratio 0.00-0.25 and Si 2.36-2.75. This area approximates Hey's sheridanite area, except for the somewhat greater Si range, 2.36-2.75 as compared with Hey's 2.50-2.80, and the type sheridanite (no. 17, table 2) falls in it; consequently it is called the sheridanite area.

The area bounded by $\mathrm{Fe}^{+2}: \mathrm{R}^{+2}$ ratio $0.26-0.75$ and Si 2.36-2.75 is designated the ripidolite area because more of the chlorites falling in this area are identified by this name than any other. As in the sheridanite area, the Si range is somewhat greater than that for Hey's ripidolite area. Hey restricts his ripidolite area to chlorites containing less than 4 percent $\mathrm{Fe}_{2} \mathrm{O}_{3}$. No such restriction is made in the present classification. Most of the chlorites that fall in the upper part of the area contain more than 4 percent $\mathrm{Fe}_{2} \mathrm{O}_{3}$ (see fig. 9), so that the presence of $\mathrm{Fe}_{2} \mathrm{O}_{3}$ seems to be more characteristic of these chlorites than not, and in many of them some of this $\mathrm{Fe}^{+3}$ is necessary for structural balance. If desired, those containing considerable $\mathrm{Fe}_{2} \mathrm{O}_{3}$ could be designated ferrian ripidolites. For example, in the list of locations and references for the analyses in table 2, ripidolites containing more than 8 percent $\mathrm{Fe}_{2} \mathrm{O}_{3}$ are called ferrian ripidolites.

The area just above the ripidolite area in figure 9 , which is bounded by $\mathrm{Fe}^{+2}: \mathrm{R}^{+2}$ ratio $0.76-1.00$ and $\mathrm{Si}$
2.36-2.75 is called the thuringite area because more than one-half of the chlorites that fall in this area were called thuringites. These are highly ferroan chlorites that usually contain considerable $\mathrm{Fe}_{2} \mathrm{O}_{3}$, although a few are low in $\mathrm{Fe}_{2} \mathrm{O}_{3}$. In many of those that contain considerable $\mathrm{Fe}_{2} \mathrm{O}_{3}$ some of the trivalent iron is necessary to structural balance. The analyses given by Dana (1892) for thuringite fall in this area. Most of these analyses also report considerable $\mathrm{Fe}_{2} \mathrm{O}_{3}$, as much as 17.66 percent, but in one no $\mathrm{Fe}_{2} \mathrm{O}_{3}$ is reported. Thus thuringite analyses in Dana like those used in this study, range widely in $\mathrm{Fe}_{2} \mathrm{O}_{3}$ content, with most of them reporting considerable $\mathrm{Fe}_{2} \mathrm{O}_{3}$, but little $\mathrm{MgO}$. In Hey's classification the name is extended to include any chlorite in which $\mathrm{Fe}_{2} \mathrm{O}_{3}$ is greater than 4 percent and $\mathrm{Si}$ occupies fewer than 2.8 positions in the half-cell formula. Thus highly magnesian as well as intermediate type chlorites become thuringites if they contain more than 4 percent $\mathrm{Fe}_{2} \mathrm{O}_{3}$ and have less than 2.8 half-cell formula positions occupied by Si. According to his classification almost all the chlorites studied herein that contain more than 4 percent $\mathrm{Fe}_{2} \mathrm{O}_{3}$ would be classified as thuringites, regardless of their $\mathrm{Fe}^{+2}: \mathrm{R}^{+2}$ ratios because most of them have less than $2.80 \mathrm{Si}$ (see fig. 9).

The chlorites that fall in the area bounded by $\mathrm{Fe}^{+2}: \mathrm{R}^{+2} 0.26-0.75$ and $\mathrm{Si} 2.76$ and 3.10 were called by a variety of names (see chart p. A-19), several of which, diabantite, chamosite, and ripidolite, have more appropriately been assigned to other areas. As the type analysis of brunsvigite falls in this area, the name brunsvigite is assigned to it, and the definition of the name is extended to include all intermediate type chlorites $\left(\mathrm{Fe}^{+2}: \mathrm{R}^{+2} 0.26-0.75\right)$ with $\mathrm{Si}$ 2.76-3.10. Thus the brunsvigite area as herein defined approximates Hey's brunsvigite and pycnochlorite areas, with no restrictions as to $\mathrm{Fe}_{2} \mathrm{O}_{3}$ content.

The two chlorites that fall in the area in figure 9 bounded by $\mathrm{Fe}^{+2}: \mathrm{R}^{+2}$ 0.76-1.00 and $\mathrm{Si}$ 2.76-3.10 were called thuringite and chamosite (Schmiedefeld). As the name thuringite has been assigned to the area to the left, the name chamosite is assigned to this area. The name chamosite is at present under somewhat of a cloud because some materials called chamosite have been found to have a $7 \mathrm{~A}$ kaolinitelike structure instead of the $14 \mathrm{~A}$ chlorite structure. However, it is believed by the writer that as the name was originally given to what was considered a chlorite, and has meant a chlorite for many years, that it should be retained as a chlorite name.

The name "diabantite" is assigned to the area 
bounded by $\mathrm{Fe}^{+2}: \mathrm{R}^{+2} 0.26-0.75$ and $\mathrm{Si}>3.10$. One of the chlorites that fall in this area was called diabantite, and the other, although given the general term "chlorite," was considered to be between diabantite and delessite in composition. No name is given to the remaining area in figure 9 , which contains only one plotted point. The chlorite represented by this point was called a thuringite, a name assigned to another area.

The presence of chromium or manganese may be noted by prefixing the species name with chromian or manganian, whichever is appropriate. None of the chlorites studied contained sufficient chromium or managanese to justify a special name.

It is obvious that the composition of members of a group like this cannot be adequately expressed by the usual kind of mineral formulas. Such formulas suggest minerals of definite composition, not members of a system that vary, within limits, in composition, and merge into one another. The generalized formulas shown below for members of the chlorite group show the limits of composition on the basis of the principal types of ions found in the chlorites that fall in the areas assigned to the respective species.

For some of these generalized formulas the ranges are based on a large number of formulas, for others, chamosite, diabantite, on only one or two. The ranges in the number of formula positions occupied by the principal trivalent and bivalent octahedral cations for the species that are adequately represented among the chlorites studied are given below:

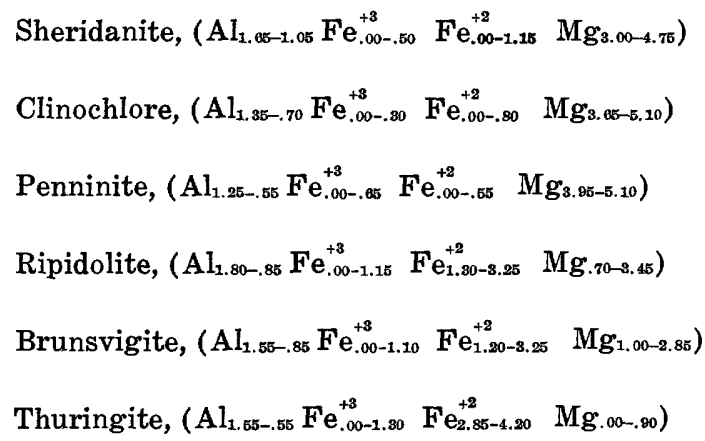

Ideally, the range for octahedral $R^{+3}$ should be the same as for tetrahedral $R^{+3}$ and octahedral $R^{+3}$ should be made up wholly of $\mathrm{Al}$. However, the ranges for the octahedral $\mathrm{Al}$ are considerably broader than the ranges for tetrahedral $\mathrm{Al}$ because of some replacement of $\mathrm{R}^{+2}$ by $\mathrm{Al}$, which results in a higher octahedral $\mathrm{Al}$ than tetrahedral $\mathrm{Al}$, and some replacement of octahedral $\mathrm{Al}$ by $\mathrm{Fe}^{+3}$, which results in a lower octahedral Al than tetrahedral Al. The distribution of points in figure 2 shows that about one-third of the chlorites studied have approximately equivalent octahedral and tetrahedral Al, within 0.10 formula positions, but that in the other two-thirds octahedral $\mathrm{Al}$ is either greater than tetrahedral $\mathrm{Al}$ by more than 0.10 formula positions (points above line $\mathrm{B}$ ) or less

$$
\begin{aligned}
& \text { Sheridanite, }\left(\mathrm{R}_{1.80-1.25}^{+3} \mathrm{R}_{4.00-4.75}^{+2}\right)\left(\mathrm{Si}_{2.85-2.78} \mathrm{Al}_{1.85-1.25}\right) \mathrm{O}_{10}(\mathrm{OH})_{8} \text {, with } \mathrm{Fe}^{+2}: \mathrm{R}^{+2}<0.25 \text {; } \\
& \underbrace{\left(R_{1.80-1.25}^{+25} R_{4.00-4.70}\right)}_{0.00-5.80} \\
& \text { Clinochlore, }\left(\mathrm{R}_{1.45-.30}^{+3} \mathrm{R}_{4.45-5.10}^{+2}\right)\left(\mathrm{Si}_{2.76-3.10} \mathrm{Al}_{1.24-.80}\right) \mathrm{O}_{10}(\mathrm{OH})_{8} \text {, with } \mathrm{Fe}^{+2}: \mathrm{R}^{+2}<0.25 \text {; } \\
& 6.00-5.80 \\
& \text { Penninite, } \underbrace{\mathrm{R}_{1.45-0.65}^{+3} \mathrm{R}_{4.25-5.45}^{+2}}_{6.00-5.75})\left(\mathrm{Si}_{3.21-3.45} \mathrm{Al} \mathrm{l}_{.80-.55}\right) \mathrm{O}_{10}(\mathrm{OH})_{8}, \text { with } \mathrm{Fe}^{+2}: \mathrm{R}^{+2}<0.25 \text {, } \\
& \text { Ripidolite, } \underbrace{\mathrm{R}_{2.44-1.25}^{+3} \mathrm{R}_{3.05-4.75}^{+2}}_{6.00-5.60})\left(\mathrm{Si}_{2.35-2.75} \mathrm{Al}_{1.65-1.25}\right) \mathrm{O}_{10}(\mathrm{OH})_{8} \text {, with } \mathrm{Fe}^{+2}: \mathrm{R}^{+2} 0.26-0.75 \text {, } \\
& \text { Brunsvigite, }(\underbrace{\mathrm{R}_{2.15-.80}^{+3} \mathrm{R}_{3.85-5.10}^{+2}}_{6.00-5.80})\left(\mathrm{Si}_{2.76-8.10} \mathrm{Al}_{1.24-.80}\right) \mathrm{O}_{10}(\mathrm{OH})_{8} \text {, with } \mathrm{Fe}^{+2}: \mathrm{R}^{+2} 0.25-0.75 \text {, } \\
& \text { Diabantite, } \underbrace{\left(\mathrm{R}_{1.40-.65}^{+3} \mathrm{R}_{4.10-5.45}^{+2}\right.})\left(\mathrm{Si}_{3.11-3.45} \mathrm{Al} .89-.55\right) \mathrm{O}_{10}(\mathrm{OH})_{8} \text {, with } \mathrm{Fe}^{+2}: \mathrm{R}^{+3} 0.26-0.75 \\
& 6.00-5.60 \\
& \text { Thuringite, }(\underbrace{+3}_{2.20-1.25} \mathrm{R}_{3.40-4.75}^{+2})\left(\mathrm{Si}_{2.36-2.75} \mathrm{Al}_{1.05-1.25}\right) \mathrm{O}_{10}(\mathrm{OH})_{s} \text {, with } \mathrm{Fe}^{+2}: \mathrm{R}^{+2} 0.76-1.00 \text {, } \\
& \underbrace{\left(R_{0.900}\right.}_{6.00-5.60} \\
& \text { Chamosite, }\left(\mathrm{R}_{1.85-.80}^{+3} \mathrm{R}_{4.00-5.10}^{+2}\right)\left(\mathrm{Si}_{2.76-3.10} \mathrm{Al}_{1.24-.80}\right) \mathrm{O}_{10}(\mathrm{OH})_{3} \text {, with } \mathrm{Fe}^{+2}: \mathrm{R}^{+2} \text { 0.76-1.00, } \\
& 6.00-5.60
\end{aligned}
$$


than tetrahedral $\mathrm{Al}$ by more than 0.10 formula positions (points below line $\mathrm{C}$ ). In most chlorites there is less octahedral Al than tetrahedral Al. Even in the range formulas for chlorites that are generally low in $\mathrm{Fe}_{2} \mathrm{O}_{3}$, like the sheridanites and clinochlores, the lows for octahedral $\mathrm{Al}$ are 0.20 formula positions lower than those for tetrahedral Al. The low for octahedral $\mathrm{Al}$ in the penninite range formula is the same as that for tetrahedral $\mathrm{Al}$, but in some individual formulas of penninites octahedral $\mathrm{Al}$ is less than tetrahedral $\mathrm{Al}$. In the range formulas for ripidolite and thuringite, the lows for octahedral $\mathrm{Al}$ are 0.40 and 0.60 positions, respectively, less than the lows for tetrahedral $\mathrm{Al}$. In these species replacement of $\mathrm{Al}$ by $\mathrm{Fe}^{+3}$ is quite general, and may be equivalent to more than one-half of the trivalent octahedral ions necessary to balance the structure. Because of this proxying of $\mathrm{Fe}^{+3}$ for $\mathrm{Al}$ in many chlorites, particularly in ferroan chlorites, no differentiation is made in this scheme of classification with respect to $\mathrm{Fe}_{2} \mathrm{O}_{3}$ content. However, chlorites containing considerable $\mathrm{Fe}_{2} \mathrm{O}_{3}$ could be designated as ferrian ripidolites, thuringites, or whatever, if desired.

The relations between the $\mathrm{Fe}^{+2}: \mathrm{R}^{+2}$ ratio and $\mathrm{Fe}_{2} \mathrm{O}_{3}$ content in chlorites is shown in the following table.

Relation between $\mathrm{Fe}^{+2}: \mathrm{R}^{+2}$ ratio and $\mathrm{Fe}_{2} \mathrm{O}_{3}$ content in chlorites

\begin{tabular}{|c|c|c|c|c|c|}
\hline \multirow{2}{*}{$\begin{array}{c}\text { Range of } \\
\mathrm{Fe}^{+2}: \mathrm{R}+2 \\
\text { ratio }\end{array}$} & \multicolumn{4}{|c|}{ Number of analyses having $\mathrm{Fe}_{2} \mathrm{O}_{3}$ : } & \multirow{2}{*}{$\begin{array}{c}\text { Average } \\
\mathrm{Fe}_{2} \mathrm{O}_{3} \\
\text { (percent) }\end{array}$} \\
\hline & $<1.00$ & $1.00-4.00$ & $>4.00$ & Total & \\
\hline $0.00-0.25 \ldots$ & 29 & 44 & $\mathbf{5}$ & 78 & 1.88 \\
\hline $0.26-0.50 \ldots$ & 2 & 16 & 13 & 31 & 4.20 \\
\hline $0.51-0.75 \ldots$ & 2 & 7 & 16 & 25 & 6.01 \\
\hline $0.76-1.00 \ldots$ & 1 & 4 & 15 & 20 & 6.60 \\
\hline
\end{tabular}

About one-third of the magnesian chlorites, sherdanites, clinochlores, and penninites, with $\mathrm{Fe}^{+2}: \mathrm{R}^{+2}$ less than 0.25 , contain less than 1.00 percent $\mathrm{Fe}_{2} \mathrm{O}_{3}$, more than one-half contain between 1.00 and 4.00 percent $\mathrm{Fe}_{2} \mathrm{O}_{3}$, and five contain more than 4.00 percent $\mathrm{Fe}_{2} \mathrm{O}_{3}$. In more than one-half of the magnesian chlorites included in this study, some or all of the $\mathrm{Fe}^{+3}$ present proxied for octahedral Al. Only two of the magnesium-dominant intermediate chlorites $\left(\mathrm{Fe}^{+2}: \mathrm{R}^{+2} 0.26-0.50\right)$ had less than 1.00 percent $\mathrm{Fe}_{2} \mathrm{O}_{3}$, almost half had more than 4.00 percent, and the rest had between 1.00 and 4.00 percent $\mathrm{Fe}_{2} \mathrm{O}_{3}$. In about 60 percent of these chlorites, octahedral $\mathrm{Al}$ was deficient and required some other trivalent octahedral ion for structural balance. About 65 percent of the ferrous iron dominant intermediate chlorites
$\left(\mathrm{Fe}^{+2}: \mathrm{R}^{+2}\right.$ 0.51-0.75) contain more than 4 percent $\mathrm{Fe}_{2} \mathrm{O}_{3}$, and all but two of the rest contain between 1.00 and 4.00 percent. About half of these chlorites are dificient in octahedral $\mathrm{Al}$, and some or all of the $\mathrm{Fe}^{+3}$ present must proxy for it, with any excess $\mathrm{Fe}^{+3}$ present proxying for $\mathrm{R}^{+2}$. In three of these ferrous iron dominant intermediate chlorites, octahedral $\mathrm{Al}$ is greatly in excess of tetrahedral $\mathrm{Al}$, with that in excess of tetrahedral Al proxying for $R^{+2}$ in a $2: 3$ ratio. Three-fourths of the ferrous chlorites $\left(\mathrm{Fe}^{+2}: \mathrm{R}^{+2} 0.76-1.00\right)$ have more than 4 percent $\mathrm{Fe}_{2} \mathrm{O}_{3}$ and only 1 of 20 has less than 1.00 percent. About 65 percent of the ferrous chlorites are deficient in octahedral Al; several are so greatly deficient that the $\mathrm{Al}$ present is sufficient to supply only about half the positive octahedral charge necessary, with $\mathrm{Fe}^{+3}$ supplying the remainder. Among the whole group of chlorites studied, 60 percent were deficient in octahedral $\mathrm{Al}, 20$ percent had octahedral $\mathrm{Al}$ equivalent to tetrahedral $\mathrm{Al}$, and about 20 percent had octahedral $\mathrm{Al}$ in excess of tetrahedral $\mathrm{Al}$. With respect to distribution as to $\mathrm{Fe}^{+2}: \mathrm{R}^{+2}$ ratio, half of the chlorites studied had a $\mathrm{Fe}^{+2}: \mathrm{R}^{+2}$ ratio of less than 0.25 , that is, were magnesian chlorites, one-third were intermediate chlorites, $\mathrm{Fe}^{+2}: \mathrm{R}^{+2} 0.26-0.75$, with significant amounts of both $\mathrm{Mg}$ and $\mathrm{Fe}^{+2}$, and about 13 percent were ferroan chlorites, with high $\mathrm{Fe}^{+2}: \mathrm{R}^{+2}$ ratio, above 0.75 .

\section{ALLOCATION OF OCTAHEDRAL CATIONS}

Throughout this study the octahedral cations have been grouped together in writing the formulas, as have been the tetrahedral cations; no differentiation has been made as to the location of the octahedral cations in the octahedral layer of the mica unit and in the brucite unit. Nor is such differentiation of octahedral cations customarily made in writing structural formulas for chlorites, yet the way in which these cations are distributed between the two octahedral layers determines the amount of negative and positive charges on the mica unit and on the brucite layer respectively, and, consequently, the bonding force between the structural units.

Pauling (1930, p. 579), in his elucidation of the chlorite structure, states that the substitution of $\mathrm{Al}^{+3}$ for $\mathrm{Si}^{+4}$ gives the mica layers a resultant negative charge, as in the micas and brittle micas themselves. This is compensated by the alternating brucite layers, each of which through the substitution of $\mathrm{Al}^{+3}$ for $\mathrm{Mg}^{+2}$ has a resultant positive charge and which play the same role as $\mathrm{K}^{+}$and $\mathrm{Ca}^{++}$in the micas and brittle micas. Brindley and Robinson (1951, p. 180) use almost the same words with respect to 
the layer-charge relations. These statements could be interpreted to mean that the negative charge on the micalike unit is due entirely to substitution of $\mathrm{Al}^{+3}$ for $\mathrm{Si}$ in the tetrahedral layers, that the octahedral layer in the micalike unit is neutral, and that all the positive charge is on the brucitelike unit, as in the following illustrations:

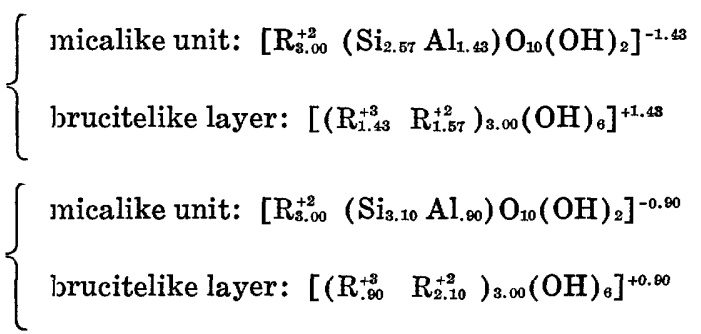

In such an allocation of octahedral cations, the respective negative and positive charges are equivalent to $\mathrm{Al}^{+3}$ replacement of $\mathrm{Si}$, and, consequently, the amount of charge binding the units together diminishes with increase in Si content from left to right in figure 9. Thus sheridanites would be characterized by higher layer charges than clinochlores, and clinochlores by higher charges than penninites.

In the formulas cited above, the octahedral trivalent ions are equivalent to the tetrahedral trivalent ions and both octahedral layers are fully occupied. In a great many chlorites, however, the octahedral trivalent cations exceed the tetrahedral trivalent cations, and octahedral occupancy is deficient. In the case under consideration, in which all the positive charge is on the brucitelike layer, the octahedral cations might be distributed as follows:

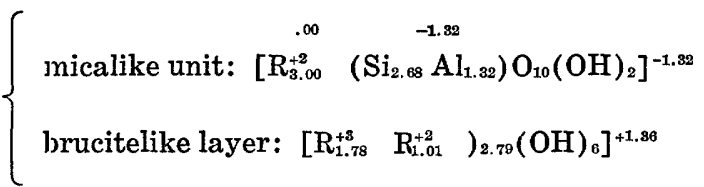

In this distribution of octahedral cations, the octahedral layer in the micalike unit is complete, and all the deficiency is in the brucitelike layer. Conversely it is possible to so allocate the octahedral cations that the deficiency is distributed between the two octahedral layers:

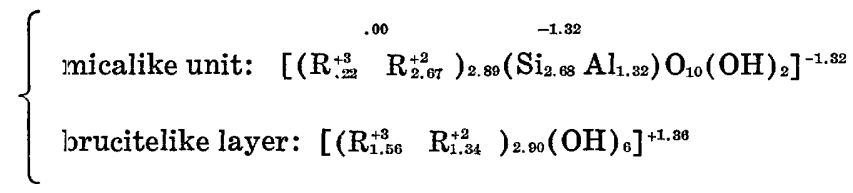

The octahedral cations may also be so allocated as to throw all the deficiency on the octahedral layer in the micalike unit, with the brucitelike unit completely occupied:

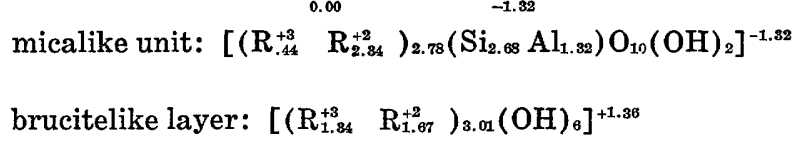

In the formula used in these illustrations of octahedral $R^{+3}$ in excess of that necessary to balance the charge, the octahedral trivalent cations are made up of $1.64 \mathrm{Al}$ and $0.14 \mathrm{Fe}^{+3}$. As the $\mathrm{Fe}_{2} \mathrm{O}_{3}$ content is fairly low, 1.93 percent, this formula represents a leptochlorite that cannot be completely reduced to orthochlorite composition by considering that the trivalent iron was originally bivalent.

If it is postulated that the chlorite may have been formed from a mica by replacing the interlayer cations with a brucitelike layer, then the micalike layer should have a charge of about 1.00 , and the octahedral layer in the micalike layer should have a positive or negative charge, or be neutral, depending on $\mathrm{Al}$ replacement in the tetrahedral layers:

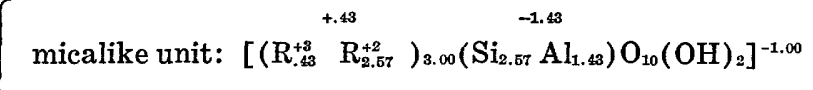

$$
\begin{aligned}
& \text { brucitelike layer: }\left[\begin{array}{ll}
\left(\mathrm{R}_{.98}^{+3}\right. & \left.\mathrm{R}_{2.03}^{+2}\right)_{3.01}(\mathrm{OH})_{6}
\end{array}\right]^{+1.00} \\
& \left\{\text { micalike unit: } \stackrel{.00}{\left[\mathrm{R}_{3.00}^{+2}\right.}\left(\mathrm{Si}_{3.02}^{-.08} \mathrm{Al}_{.08}\right) \mathrm{O}_{10}(\mathrm{OH})_{2}\right]^{-.98} \\
& \text { brucitelike layer: }\left[\begin{array}{lll}
\left(R_{.08}^{+3}\right. & R_{2.02}^{+2} & )_{3.01}(O H)_{6}
\end{array}\right]^{+.98} \\
& \text { micalike unit: }\left[\mathrm{R}_{2.83}^{+2}\left(\mathrm{Si}_{3.45}^{-.55} \mathrm{Al}_{.55}\right) \mathrm{O}_{10}(\mathrm{OH})_{2}\right]^{-.89}
\end{aligned}
$$

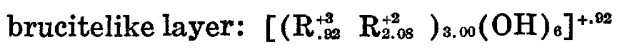

If tetrahedral $\mathrm{Al}$ is greater than 1.00 , the octahedral layer in the micalike unit has a positive charge, and the composition of the unit and its layer charge relations resemble that of a trioctahedral mica in which there has been some trivalent octahedral substitution (Foster, 1960). If tetrahedral $\mathrm{Al}$ is close to 1.00 , the octahedral layer in the micalike unit is neutral, or almost so, and the composition of the unit is similar to that of phlogopite. If tetrahedral $\mathrm{Al}$ is considerably less than 1.00 , the octahedral layer in the micalike unit must also have a negative charge if the total negative charge on the unit is to approach 1.00 . The total negative charge is then the sum of two negative charges, one on the octahedral, one on the tetrahedral layers, as in dioctahedral micas in which there has been some bivalent ion substitution. However, the composition of the micalike unit does not resemble that of a dioctahedral mica, because it is composed of bivalent ions, and the number of octahedral ions is considerably in excess of 2.00 , nor does 
the composition resemble that of a trioctahedral mica unit, as the octahedral layers of such micas contain some trivalent ions when octahedral occupancy is deficient, as in the example.

It is conceivable also that neutralization of the tetrahedral charge occurs within the micalike unit, so that this unit and also the brucite layer are neutral, as pointed out by Brindley and Gillery (1956, p. 172) :

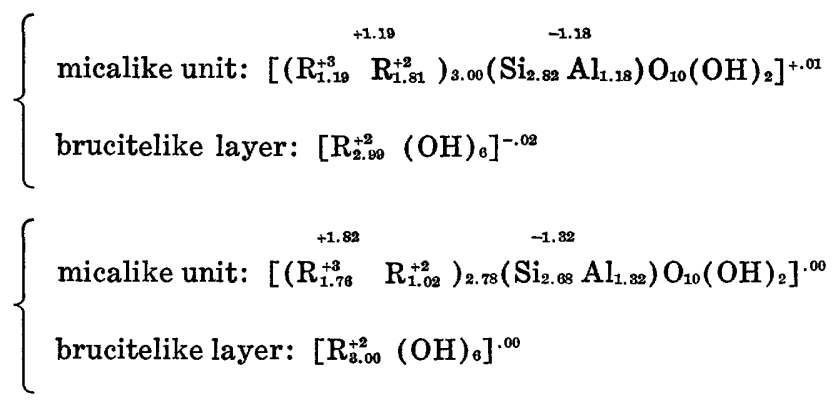

Such a condition seems unlikely, however, as there is no bonding force between the constituent units.

In the schemes for the distribution of octahedral cations that have been considered, the two octahedral layers are dissimilar in composition. The only scheme for the distribution of octahedral cations that produces symmetrical octahedral layers is that in which each species of cation is divided as equally as possible between the two octahedral layers:

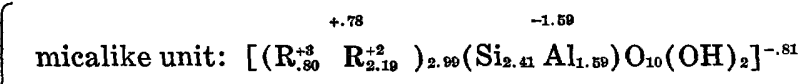

$$
\begin{aligned}
& \text { brucitelike layer: }\left[\left(\begin{array}{ll}
\mathrm{R}_{.81}^{+8} & \mathrm{R}_{2.18}^{+2}
\end{array}\right)_{2.90}(\mathrm{OH})_{6}\right]^{+.79}
\end{aligned}
$$

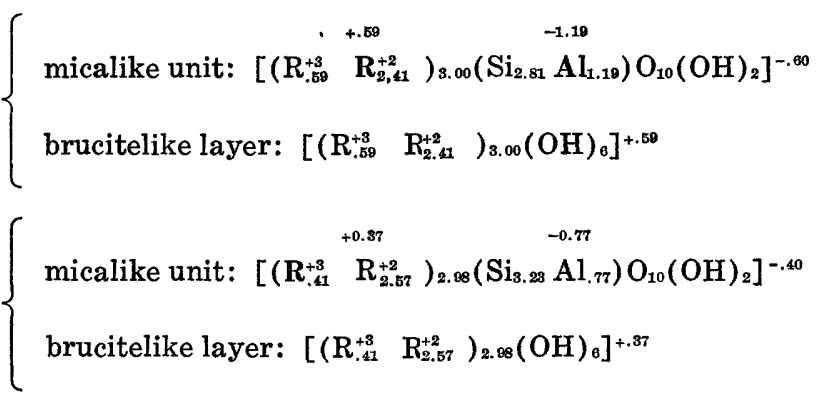

In this method of allocating octahedral cations, half the negative charge on the tetrahedral layers is neutralized within the micalike unit itself, and half is neutralized by the positive charge on the brucitelike layer. Thus the charge bonding force between the structural units is only one-half as great as in the first scheme considered, but, as in that scheme, decreases with increase in Si content. Gruner (1944) and Bannister and Whittard (1945) correlated increase in the basal spacing, $d(001)$, with increase in the Si/Al(IV). Bannister and Whittard (p. 108) consider that " $* * *$ this is to be expected, since the charge on the micalike layers will become smaller with decrease in $\mathrm{Al}$ and the layers will not be as tightly bonded together."

If the octahedral layers are also identical in composition, and successive tetrahedral and octahedral layers have alternating negative and positive charges of the same magnitude, conversion from the $14 \mathrm{~A}$ chlorite to the $7 \mathrm{~A}$ kaolin type structure, or vice versa, would not require rearrangement of octahedral cations, but requires only that $\mathrm{Si}$ atoms be moved from the centers of tetrahedral oxygen groups to corresponding positions on the opposite side of the oxygen sheet and then linked to oxygen atoms in the adjacent brucite layer. Such a mechanism is suggested by Brindley and Gillery (1954) to account for the series of basal X-ray reflections given by a mineral called daphnite but interpreted by them as a mixed layer kaolin-chlorite structure.

\section{SUMMARY AND CONCLUSIONS}

Relatively few chlorites have octahedral Al approximately equivalent to tetrahedral $\mathrm{Al}$, as is ideally assumed; most chlorites have either more or less octahedral than tetrahedral Al. In chlorites in which octahedral $\mathrm{Al}$ is low, some other trivalent cation, usually $\mathrm{Fe}^{+3}$, occasionally $\mathrm{Cr}^{+3}$, must be present to proxy for $\mathrm{Al}$ in providing sufficient octahedral positive charges to balance the negative tetrahedral charge. If the sum of the octahedral trivalent cations, whether made up entirely of $\mathrm{Al}$, or of $\mathrm{Al}, \mathrm{Fe}^{+3}$, and (or) $\mathrm{Cr}^{+3}$, is about equivalent to tetrahedral $\mathrm{Al}$, octahedral occupancy is 6.00 , or close to 6.00 , but if the sum of the octahedral trivalent cations is greater than tetrahedral $\mathrm{Al}$, octahedral occupancy is less than 6.00 by an amount about equal to one-half the excess of octahedral trivalent cations over tetrahedral Al. This relationship indicates that the excess octahedral trivalent cations have replaced $R^{+2}$ cations in the ratio of $2: 3$.

No correlation was found between the amount of $\mathrm{Fe}_{2} \mathrm{O}_{3}$ present and $\mathrm{O}$ content as calculated on the basis of determined $\mathrm{H}_{2} \mathrm{O}(+)$. Some chlorites containing considerable $\mathrm{Fe}_{2} \mathrm{O}_{3}$ had a normal or somewhat deficient $O$ content and others had less $O$ than would be expected if the $\mathrm{Fe}_{2} \mathrm{O}_{3}$ were due to secondary oxidation of $\mathrm{FeO}$. In many chlorites some or all of the $\mathrm{Fe}_{2} \mathrm{O}_{3}$ is a necessary constituent for structural balance because of low octahedral Al. This is particularly true of ferrous chlorites, many of which contain considerable $\mathrm{Fe}_{2} \mathrm{O}_{3}$. As many chlorites are formed as the result of alteration of other minerals, some of which contain $\mathrm{Fe}_{2} \mathrm{O}_{3}$, it is to be expected that $\mathrm{Fe}^{+3}$ ions would be incorporated into the chlorite struc- 
ture. $\mathrm{Fe}_{2} \mathrm{O}_{3}$ should, therefore, not arbitrarily be considered the result of secondary oxidation, but should be considered a normal constituent unless there is other evidence of secondary oxidation.

Two series of ionic replacement characterize the chlorites, replacement of tetrahedral and octahedral $\mathrm{Al}$ by $\mathrm{Si}$ and $\mathrm{Mg}$, and replacement of $\mathrm{Mg}$ by $\mathrm{Fe}^{+2}$. Replacement of tetrahedral and octahedral Al takes place in accordance with the equation,

$$
\mathrm{Si}+\mathrm{Mg}=\mathrm{Al}(\mathrm{IV})+\mathrm{Al}(\mathrm{VI}),
$$

and, consequently, involves both the tetrahedral and octahedral layers and changes the layer charges; replacement of $\mathrm{Mg}$ by $\mathrm{Fe}^{+2}$ is ion for ion and involves only the octahedral layers, and causes no change in layer charges. Replacement of tetrahedral and octahedral $\mathrm{Al}$ amounts to about one formula position in the group of chlorites studied, from abrout $\left(\mathrm{Al}_{1.60} \mathrm{Mg}_{4.40}\right)\left(\mathrm{Si}_{2.40} \mathrm{Al}_{1.60}\right) \mathrm{O}_{10}(\mathrm{OH})_{8}$ to about $\left(\mathrm{Al}_{0.60} \mathrm{Mg}_{5.40}\right)\left(\mathrm{Si}_{3.40} \mathrm{Al}_{0.60}\right) \mathrm{O}_{10}(\mathrm{OH})_{8}$, and is represented most fully by the highly magnesian chlorites. The replacement of $\mathrm{Mg}$ by $\mathrm{Fe}^{+2}$ is demonstrated most continuously and completely by chlorites in the lower part of the Si range, Si 2.50-2.75, where the full range of replacement from wholly magnesian to wholly ferroan is represented in the group studied.

A classification of the chlorites is based on these two series of ionic replacements. With respect to $\mathrm{Si}$ content the chlorites are divided into three groups, those in which Si occupies, respectively, fewer than 2.75 formula positions, between 2.75 and 3.10 formula positions, and more than 3.10 formula positions. With respect to $\mathrm{Mg}: \mathrm{Fe}^{+2}$ ratio there is also a threeway division, the highly magnesian, with $\mathrm{Fe}^{+2}: \mathrm{R}^{+2}$ less than 0.25 ; the intermediate, with $\mathrm{Fe}^{+2}: \mathrm{R}^{+2}$ between 0.25 and 0.75 ; and the highly ferroan, with $\mathrm{Fe}^{+2}: \mathrm{R}^{+2}$ greater than 0.75 . This division with respect to $\mathrm{Fe}^{+2}: \mathrm{R}^{+2}$ ratio is similar to that of the trioctahedral micas into phlogopites, biotites, and siderophyllites-lepidomelanes. The nine species into which the chlorites are divided are, therefore, strictly defined with respect to $\mathrm{Si}$ content and $\mathrm{Fe}^{+2}: \mathrm{R}^{+2}$ ratio.

After considerations of various schemes for the distribution of octahedral cations between the octahedral layer in the micalike unit and the brucitelike layer the equal distribution of the various kinds of octahedral cations between the two octahedral layers seems to correlate best with the increase of basal spacing, $d$ (001), with increase in Si content that has been observed, and with the conversion of chlorite units to two kaolin-type units and vice versa that has been experimentally produced. However, the way the octahedral cations are distributed between the two layers may differ in different types of chlorites.

\section{REFERENCES CITED}

Bannister, F. A., and Whittard, W. F., 1945, A magnesian chamosite from the Wenlock Limestone of Wickwar, Gloucestershire: Mineralog. Mag., v. 27, p. 99-111.

Brindley, G. W., and Robinson, K., 1951, The chlorite minerals, in Brindley, G. W., ed., X-ray identification and crystal structures of clay minerals: The Mineralog. Soc. (Clay minerals group), London, p. 173-198.

Brindley, G. W., and Gillery, F. H., 1954, A mixed-layer kaolin-chlorite structure, in Swineford and Plummer, eds., Clays and Clay Minerals: Natl. Acad. Sci.-Natl. Research Council Pub. 327, p. 349-353.

— 1956, X-ray identification of chlorite species: Am. Mineralogist, v. 41, p. 169-186.

Dana, E. S., 1892, The system of mineralogy, 6th ed.: New York, John Wiley and Sons, p. 649, 652, 657.

Dschang, G. L., 1931, Die Beziehungen zwischen chemischer Zusammensetzung und den physikalisch-optischen Eigenschaften in der Chloritgruppe: Chemie der Erde, v. 6, p. $416-439$.

Faust, George T., 1955, Thermal analyses and X-ray studies of griffithite: Washington Acad. Sci. Jour., v. 45, p. 66-69.

Foster, M. D., 1960, Interpretation of the composition of trioctahedral micas: U.S. Geol. Survey Prof. Paper 354-B, p. $11-49$.

Gruner, J. W., 1944, The kaolinite structure of amesite, $(\mathrm{OH})_{8}(\mathrm{Mg}, \mathrm{Fe})_{4} \mathrm{Al}_{2}\left(\mathrm{Si}_{2} \mathrm{Al}_{2}\right) \mathrm{O}_{10}$, and additional data on chlorites: Am. Mineralogist, v. 29, p. 422-430.

Hallimond, A. F., 1939, On the relation of chamosite and daphnite to the chlorite group, with chemical analyses: Mineralog. Mag., v. 25, p. 441-464.

Hendricks, S. B., 1939, Random structures of layer minerals as illustrated by cronstedtite $\left(2 \mathrm{FeO} \mathrm{Fe}_{2} \mathrm{O}_{3} \cdot \mathrm{SiO}_{2} \cdot 2 \mathrm{H}_{2} \mathrm{O}\right)$. Possible iron content of kaolin: Am. Mineralogist, v. 24, p. 529-539.

Hey, M. H., 1954, A new review of the chlorites: Mineralog. Mag., v. 30, p. 277-292.

Holzner, Julius, 1938, Beiträge zur Kenntnis der varistischen Gesteins- und Mineralprovinz im Lahn-Dillgebeit. 7. Eisenchlorite aus dem Lahngebiet; chemische Formel und Valenzausgleich bei den Eisenchloriten: Neues Jahrb. Mineralogie, Geologie u. Paläontologie, Beilage-Band 73, Abt. A., p. 389-418.

Mauguin, Ch., 1928, Etude des chlorites au moyen des rayons $\mathrm{X}$ : Acad. Sci. (Paris) Comptes Rendus, v. 186, 1852-1855. 1930, La maille cristalline des chlorites: Soc. française Minéralogie Bull., v. 53, p. 279-300.

Orcel, J., 1926, Essai de classification des chlorites: Acad. Sci. (Paris) Comptes Rendus, v. 183, p. 363-365.

Pauling, Linus, 1930, The structure of the chlorites: [U.S.] Natl. Acad. Sci. Proc., v. 16, p. 578-582. 
Polovinkina, Y. I., and Ivanova, V. P., 1953, Chlorites and hydromicas from Krivoy Rog.: Voprosy Petrog. i Mineral., Akad Nauk SSSR, v. 2, p. 161-181 [In Russian]

Tschermak, G., 1890, Die Chloritgruppe, Teil I: Akad. Wiss. Wien Sitzungsber., Math-naturw. Kl., Abt. I, v. 99, p. 174-267.

1891, Die Chloritgruppe, Teil II: Akad. Wiss. Wien
Sitzungsber., Math.-naturw. Kl., Abt. I, v. 100, p. 29-107. Winchell, A. N., 1926, Chlorite as a polycomponent system: Am. Jour. Sci., 5th ser., v. 11, p. 283-300.

1928, Additional notes on chlorite: Am. Mineralogist, v. 13, p. 161-170.

1936, Third study of chlorite: Am. Mineralogist, v. 21, p. $642-651$. 


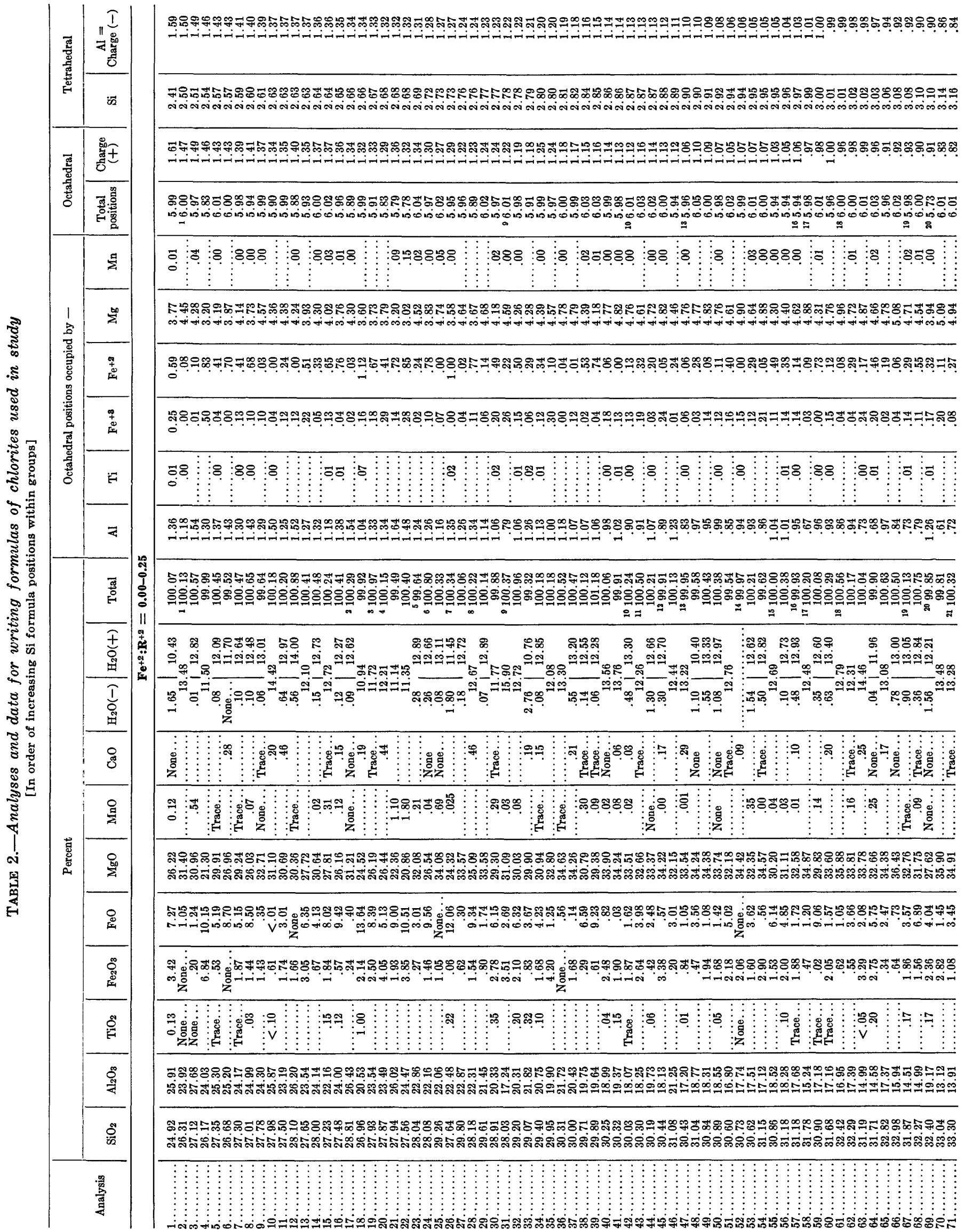


이을

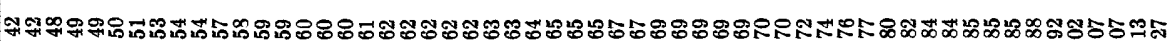

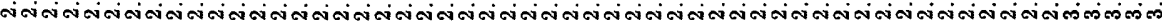

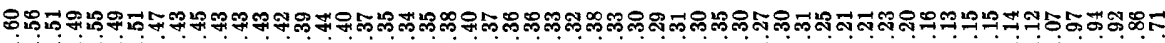

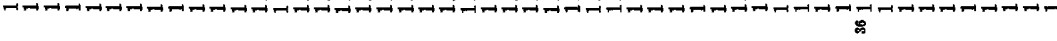

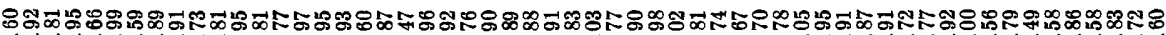

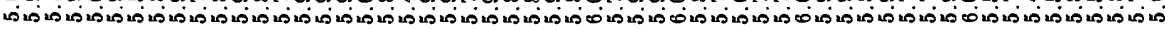

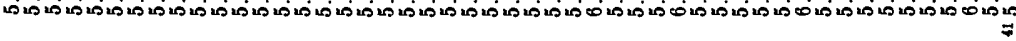

引 ๓

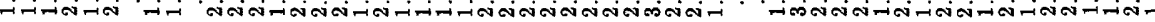

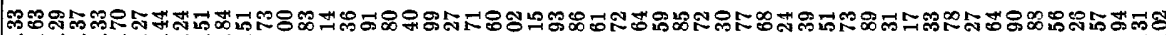
-

か

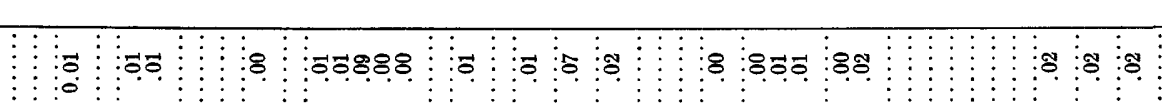

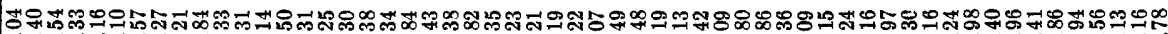
10

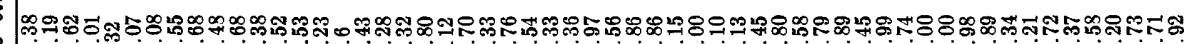

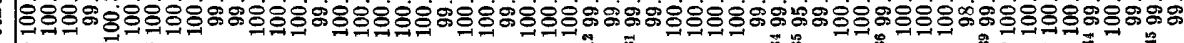

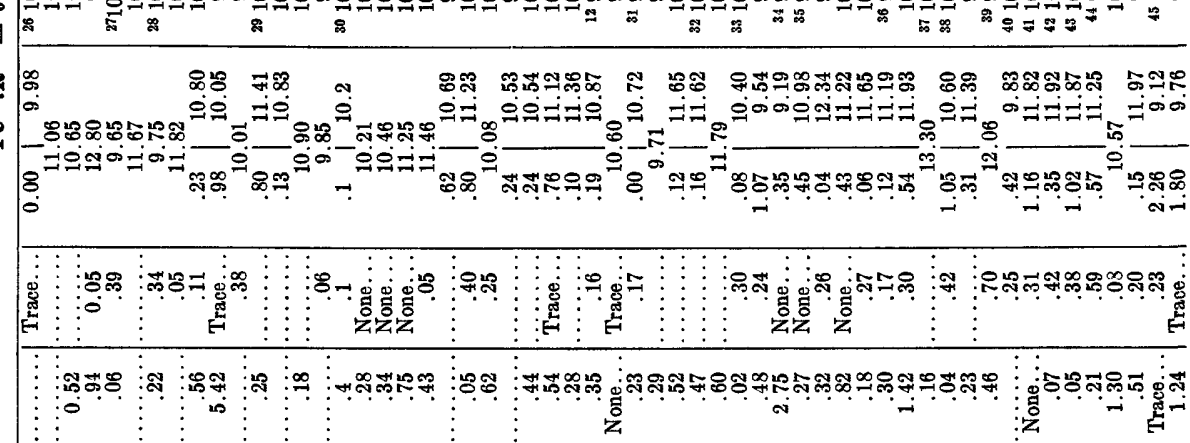

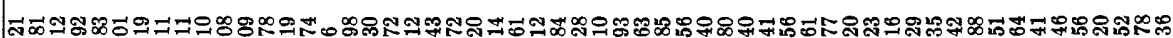

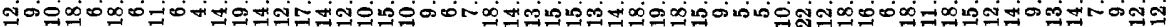

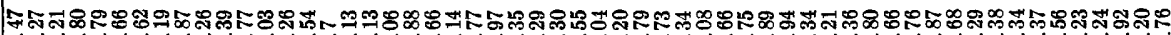

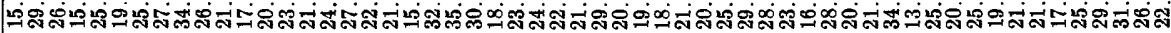

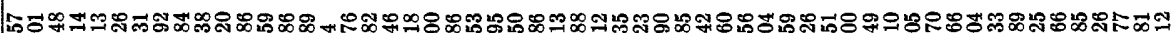

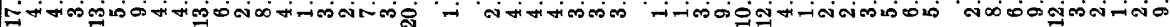

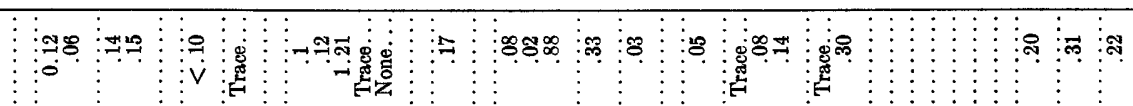

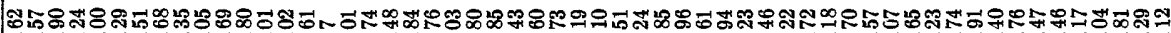

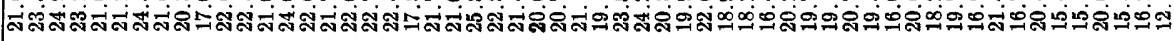

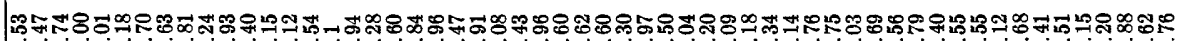

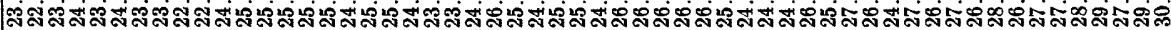


INTERPRETATION OF THE COMPOSITION AND A CLASSIFICATION OF THE CHLORITES
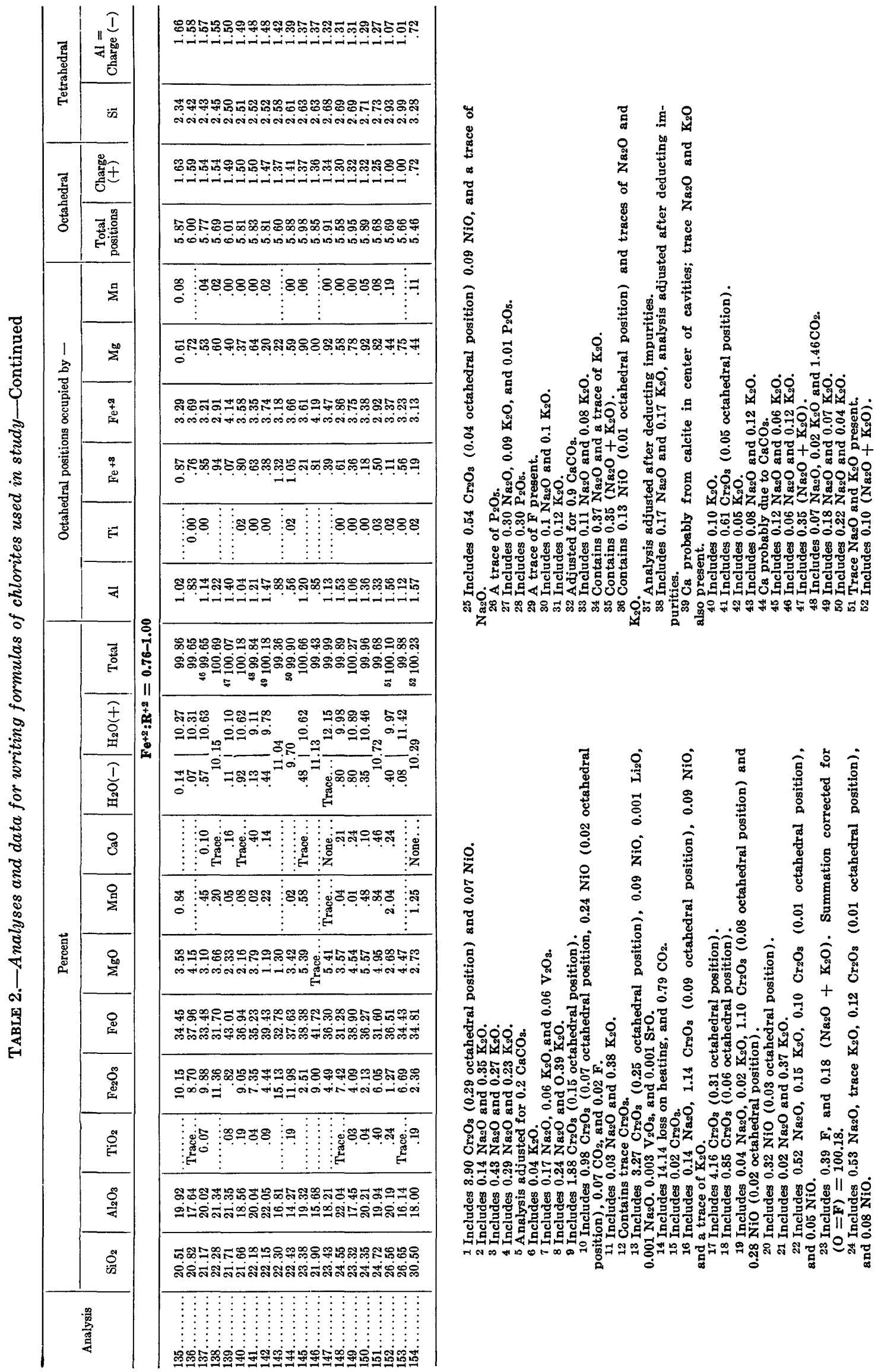
References and localities for analyses in table 2

[In these references the locality name is quoted and the published species name is given. Species names according to the classification herein proposed appear in center headings ]

\section{Sheridanite}

1. Iskyul, V., 1917, Experimental investigations in the province of the chemical constitution of the silicates. The chlorites, Petrograd, [Mineralog. Abs. v. 2, p. 215]. Chester, Mass. Corundophilite.

2. Phillips, W. R., 1954, Ph. D. Thesis, Univ. of Utah. Eldorado City, Colo., Clinochlore.

3. Orcel, J., 1924, Acad. Sci. (Paris) Comptes Rendus, v. 178, p. 1729. Comberousse valley, Belledonne mountains, Isère, France. Chlorite.

4. Kurnakov, N. S., and Chernyckh, V. V., 1926, Mineralog. Obshch. Zapiski v. 55 , pt. 1 , p. 187 , no. 16 , Belgium. Klementite.

5. Orcel, J., 1923, Acad. Sci. (Paris) Comptes Rendus, v. 176, p. 1233. Carter's mine, Madison County, N. C. Prochlorite.

6. Ross, C. S., 1935, U.S. Geol. Survey Prof. Paper 179, p. 66. Burra Burra mine, Ducktown, Tenn. Chlorite.

7. Pavlovitch, St., 1931, Soc. française Minéralogie Bull. 53, p. 536. Corundum Hill, Macon County, N. C. Grochauite.

8. Lacroix, A., 1922, Acad. Sci. (Paris) Comptes Rendus, v. 174, p. 903. Antohidrano, Madagascar. Grochauite.

9. Shannon, E. V., and Wherry, E. T., 1922, Washington Acad. Sci. Jour., v. 12, p. 240. Wyoming(?) Sheridanite.

10. Phillips, W. R., 1954, Ph. D. Thesis, Univ. of Utah. Miles City, Mont. Sheridanite.

11. Pavlovitch, St., 1931, Soc. française Minéralogie Bull., v. 53, p. 537. Kalinski, Urals, Russia. Grochauite.

12. Shannon, E. V., and Wherry, E. T., 1922, Washington Acad. Sci. Jour., v. 12, p. 240. Brinton's Quarry, Chester County, Pa. White chlorite.

13. Hödl, A., 1941, Neues Jahrb. Mineralogie, Geologie u. Paläontologie, Beil.-Band 77, Abt. A, p. 24. Häuselberg, near Loeben, Styria, Austria. Grochauite.

14. Orcel, J., 1927, Soc. française Minéralogie Bull., v. 50, p. 206. Carter mine, Democrat, N. C. Prochlorite.

15. Iskyul, V., 1917, Experimental investigations in the province of the constitution of the silicates. The chlorites. Petrograd, [Mineralog. Abs. v. 2, p. 215]. Meerbrecht, Tyrol. Prochlorite.

16. Orcel, J., 1927, Soc. française Minéralogie Bull., v. 50, p. 216. Leydsdorp district, Transvaal, [Union of South Africa]. Prochlorite.

17. Wolff, J. E., 1912, Am. Jour. Sci., ser. 4, v. 34, p. 476. Northern Wyoming. Sheridanite.

18. Phillips, W. R., 1954, Ph. D. Thesis, Univ. of Utah. Chester, Vt. Prochlorite.

19. Orcel, J., 1927, Soc. française Minéralogie Bull., v. 50, p. 347 , no. 37 , table 8 . Häuselberg, near Leoben, Styria, Austria. Rumpfite.

20. Dschang, G. L., 1931, Chemie der Erde, v. 6, p. 420 , no. 2. Achmatowsk, Urals, Russia. Clinochlore.

21. Mélon, J., 1938, Acad. royale Belgique cl. sci., Mem. (in- $\left.{ }^{\circ}\right)$, v. 17 , p. 23. Regné, Belgium. Chlorite.

22. Mélon, J., 1938, Acad. royale Belgique cl. sci. Mem. $\left(\right.$ in- $\left.8^{\circ}\right)$, v. 17 , p. 19 . Vielsalm, Belgium. Klementite.
23. Shirozu, H., 1958, Mineralog. Jour. Japan, v. 2, p. 211, no. 2, in skarn. Kamaishi mine, Iwate Pref., Japan. Chlorite.

24. Simpson, E. S., 1936, Royal Soc. Western Australia Jour., v. 22, p. 3. Holleton, South-west Division, Western Australia. Corundophilite.

25. Okamoto, Y., and Shirozu, H., 1957, Fukuoka Univ. Fac. Sci. Mem., ser. D., v. 5, p. 186. Muramatsu, Nagasaki Pref., Japan. Mn Leuchtenbergite.

26. Hutton, C. O., and Seelye, F. T., 1945, Royal Soc. New Zealand, Trans. and Proc., v. 75, p. 163. Aorere, Nelson, New Zealand. Corundophilite.

Clinochlore

27. Hödl, A., 1941, Neues Jahrb. Mineralogie, Geologie, u. Paläontologie, Beil.-Band 77, Abt. A, p. 23. Oberdorf, bei St. Kathrein an-der-Laming, Styria, Austria. Leuchtenbergite.

28. Orcel, J., 1927, Soc. française Minéralogie Bull. v. 50, p. 347 , no. 38 , Table 8 . Häuselberg, near Leoben, Styria, Austria. Rumpfite.

29. Hödl, A., 1941, Neues Jahrb. Mineralogie, Geologie, u. Paläontologie, Beil.-Band 77, Abt. A, p. 23. Kaintaleck, Styria, Austria. Leuchtenbergite (Klinochlor).

30. Iskyul, V., 1917, Experimental investigations in the province of the chemical constitution of the silicates. The chlorites, Petrograd, [Mineralog. Abs. v. 2, p. 215]. Nizhne-Issetsk estate, Urals, Russia. Clinochlore.

31. Garrido, J., 1949, Soc. française Minéralogie et Crystallographie Bull. v. 72, p. 551. Sierra de la Capelada, Galicia, Spain. Chlorite.

32. Phillips, W. R., 1954, Ph. D. Thesis, Univ. of Utah. Harford County, Md. Prochlorite.

33. Harada, Z., 1959, Hokkaido Univ. Fac. Sci. Jour., ser. 4, v. 10, p. 80 . Wanibuchi mine, Hirata City, Simaná Pref., Japan. Chlorite.

34. Orcel, J., 1927, Soc. française Minéralogie Bull., v. 50, p. 201. Ambatofinandrahana Prov., Madagascar. Prochlorite.

35. Kurnakov, N. S., and Chernykh, V. V., 1926, Mineralog. Obshch. Zapiski, v. 55, pt. 1, p. 187, no. 4. Achmatovsk, Nazyamisk mountains, southern Urals, Russia. Clinochlore.

36. Orcel, J., 1925, Acad. Sci. (Paris) Comptes Rendus, v. 180 , p. 1673. Midongy, Ambatofinandrahana Prov., Madagascar. Leuchtenbergite.

37. Clarke, F. W., 1910, U.S. Geol. Survey Bull. 419, p. 293, C. Slatoust, Urals, Russia. Leuchtenbergite.

38. Shirozu, H., 1958, Mineralogical Jour. Japan, v. 2, p. 211, no. 3. Sannō, Fukuoka Pref., Japan. Chlorite.

39. Shirozu, H., 1958, Mineralogical Jour. Japan, v. 2, p. 211, no. 5. Wakimisaki, Nagasaki Pref., Japan. Chlorite.

40. Iskyul, V., 1917, Experimental investigations in the province of the chemical constitution of the silicates. The chlorites, Petrograd, [Mineralog. Abs. v. 2, p. 215]. Nazyamsk mountains, Urals, Russia. Clinochlore.

41. Iskyul, V., 1917, Experimental investigations in the province of the chemical constitution of the silicates. The chlorites, Petrograd, [Mineralog. Abs. v. 2, p. 215]. Shishimsky mine, southern Urals, Russia. Leuchtenbergite.

42. Hla, T., 1945, Mineralog. Mag., v. 27, p. 139. West Chester, Pa. Clinochlore. 
43. Dschang, G. L., 1931, Chemie der Erde, v. 6, p. 420, no. 3. West Town, Pa. Clinochlore.

44. Serdyuchenko, D. P., 1953, Chlorites, their chemical constitution and classification, Izdel. Akad. Nauk. SSSR Moscow, p. 176, table 60, no. 2. Angar river, U.S.S.R. Chlorite.

45. Kitahara, J., 1955, Japanese Assoc. Mineralogists, Petrologists, and Economic Geologists Jour., v. 39, p. 173. Hinokami mine, Tari district, Tottori Pref., Japan. Leuchtenbergite.

46. Orcel, J., 1927, Soc. française Minéralogie Bull., v. 50, p. 353, no. 73, table 13. Rauenthal, Markirch, Alsace, France. Clinochlore.

47. Osborne, F. F., and Archambault, M., 1948, Royal Soc. Canada Trans., ser. 3, v. 42, sec. 4, p. 66. Mount Albert, Quebec, Canada. Clinochlore.

48. Durrell, C., and MacDonald, G. A., 1939, Am. Mineralogist v. 24, p. 454. Near Kings River, Calif. Clinochlore.

49. Clarke, F. W., 1910, U.S. Geol. Survey Bull. 419, p. 293, B. Nikolai-Maximilian mine, Slatoust district, Urals, Russia. Clinochlore.

50. Serdyuchenko, D. P., 1953, Chlorites, their chemical constitution and classification, Izdel. Akad. Nauk SSSR., Moscow, p. 176, table 60, no. 1. Angar river, U.S.S.R. Chlorite.

51. Rondolino, R., 1936, Periodico Mineralog., Roma, v. 7, p. 199. Piampaludo, Piedmont, Italy. Clinochlore.

52. Ivanova, V. P., 1949, Akad. Nauk SSSR Geol. Inst., Trudy, v. 120 , p. 63. Location not given. Leuchtenbergite.

53. Tajder, M., 1938, Inst. Geol. Kraljevine Jugoslavije Vesnik, v. 6, p. 235. Dobro Polje, Serbia, Yugoslovia. Clinochlore.

54. Kitahara, J., 1955, Japanese Assoc. Mineralogists, Petrologists, and Economic Geologists Jour., v. 39, p. 169, Hinokami mine, Tare district, Tottori Pref.; Japan. Leuchtenbergite.

55. Du Rietz, T., 1935, Geol. Fören. Stockholm Förh., v. 57, p. 188. Muruhatten, Sweden. Clinochlore.

56. Orcel, J., 1927, Soc. française Minéralogie Bull., v. 50, p. 267. South of Maevatanana, Madagascar. Clinochlore.

57. Lapham, D. M., 1958, Am. Mineralogist, v. 43, p. 923. West Chester, Pa. Chromian chlorite.

58. Orcel, J., Acad. Sci. (Paris) Comptes Rendus, v. 180, p. 837. Patevi, $20 \mathrm{~km}$. SSE of Atakpame, Togo, Africa. Clinochlore.

59. Hutton, C. O., 1936, Royal Soc. New Zealand Trans. and Proc., v. 66, p. 36. Red Mountain, south Westland, New Zealand. Chlorite.

60. Ivanova, V. P., 1949, Akad. Nauk. SSSR. Geol. Inst. Trudy, v. 120, p. 63. Location not given. Clinochlore.

61. Orcel, J., 1925, Acad. sci. (Paris) Comptes Rendus, v. 180, p. 837 . Patevi, $20 \mathrm{~km}$. SSE of Atakpame, Togo, Africa. Clinochlore.

62. Smith, W. C., 1924, Mineralog. Mag. v. 20, p. 242. Bernstein, Austria. Clinochlore.

63. Phillips, W. R., 1954, Ph. D. Thesis, Univ. of Utah. Brewster, N. Y. Clinochlore.

64. Serdyuchenko, D. P., 1953, Chlorites, their chemical constitution and classification, Izdel. Akad. Nauk SSSR, Moscow, p. 147, table 47, no. 1. Beskes river, U.S.S.R. Chlorite.
65. Vavrinecz, G., 1927, Magyar Chemiai Folyóirat, Budapest, v. 33, p. 186, no. 1. Bernstein, Austria. Pseudophite.

66. Satō, S., 1933, Shanghai Sci. Inst. Jour., sec. 11, v. 1, p. 18. Near Syunkōdō, Korea. Leuchtenbergite.

67. Hutton, C. O., 1947, Royal Soc. New Zealand Trans. and Proc., v. 76 , p. 488 , no. 1. Kaukapakapa, North Aukland, New Zealand. Leuchtenbergite.

68. Shirozu, H., 1958, Mineralog. Jour. Japan, v. 2, p. 211, no. 4. Okusi, Nagasaki Pref. Japan. Chlorite.

69. Simpson, E. S., 1936, Royal Soc. Western Australia Jour., v. 22, p. 3. Ninghanboun Hills, Southwest Division, Western Australia. Clinochlore.

\section{Penninite}

70. Kurnakov, N. S., and Chernykh, V. V., 1926, Mineralog. Obshch. Zapiski v. 55, p. 187, no. 2. Shishimsk mountains, Zlatoust region, southern Urals, Russia. Penninite.

71. Dschang, G. L., 1931, Chemie der Erde, v. 6, p. 420, no. 6. Locality not given. Pennine.

72. Lapham, D. M., 1958, Am. Mineralogist, v. 43, p. 923. Zermatt, Valais, Switzerland. Chromian chlorite.

73. Ivanova, V. P., 1949, Akad. Nauk SSSR. Geol. Inst. Trudy, v. 120, p. 63. Location not given. Penninite.

74. Iskyul, V., 1917, Experimental investigations in the province of the chemical constitution of the silicates. The chlorites, Petrograd, [Mineralog. Abs. v. 2, p. 215]. Pfitschtal, Tyrol. Pennine.

75. Ivanova, V. P., 1949, Akad. Nauk SSSR Geol. Inst. Trudy, v. 120, p. 63. Location not given. Tabergite.

76. Lapham, D. M., 1958, Am. Mineralogist, v. 43, p. 923. Chester County, Pa. Chromian chlorite.

77. Bertolani, M., 1949, Comit. Sci. Centr. Club. Alpino Italiano Modena, Mem. no. 1, p. 53. Secchia valley, Appennines region, Italy. Pennine.

78. Lapham, D. M., 1958, Am. Mineralogist, v. 43, p. 923. Ogushi, Hizen, Japan. Chromian chlorite.

\section{Ripidolite}

79. Hödl, A., 1941, Neues Jahrb. Mineralogie, Geologie, u. Paläontologie, Beil.-Band 77, Abt. A, p. 26. KleinLitzner, Silvretta, Tyrol-Voralberg. Prochlorite.

80. Hödl, A., 1941, Neues Jahrb. Mineralogie, Geologie, u. Paläontologie, Beil.-Band 77, Abt. A, p. 27. Granitzer, near Weiz, Styria, Austria. Fe-prochlorite.

81. Mélon, J., 1938, Acad. royale Belgique Bull. cl. sci. Mem. (in- $8^{\circ}$ ), v. 17 , no. 4 , p. 25 , no. 3 . Serpont Recogne, Belgium. Chlorite.

82. Phillips, W. R., 1954, Ph. D. Thesis, Univ. of Utah. Chester, Mass. Corundophilite.

83. Holzner, J., 1938, Neues Jahrb. Mineralogie, Geologie, u. Paläontologie, Beil.-Band 73, Abt. A, p. 401, no. 2. Georg-Joseph, Lahn-Dillgebiet, Germany. Aphrosidrite.

84. Vavrinecz, G., 1932, Maygar Chemiai Folyóirat, Budapest, v. 38, p. 143, no. 5. Zillerthal, Austria. Helminthe.

85. Ontoev, D. O., 1956, Akad. Nauk SSSR Izv. ser. geol. no. 4, p. 46, no. 1. Shadskaya, U.S.S.R. Thuringite.

86. Phillips, W. R., 1954, Ph. D. Thesis, Univ. of Utah. Simplon Tunnel, Switzerland. Prochlorite.

87. Shirozu, H., 1958, Mineralog. Jour. Japan, v. 2, p. 212, no. 10. Sayama mine, Akita Pref., Japan. Chlorite. 
88. Sudo, T., 1943, Chemical Soc. Japan Bull., v. 18, p. 289. Tateyama Hot Springs, Jôdojama, Toyama Pref., Japan. Mn-thuringite.

89. Phillips, W. R., 1954, Ph. D. Thesis, Univ. of Utah. Southbury, Conn. Prochlorite.

90. Clarke, F. W., 1910, U.S. Geol. Survey Bull. 419, p. 294. Aqueduct Tunnel, Washington, D. C. Prochlorite.

91. Hödl, A., 1941, Neues Jahrb. Mineralogie, Geologie, u. Paläontologie, Beil.-Band 77, Abt. A, p. 25, no. 4. Shottgraben near Frohleiten, Styria, Austria. Prochlorite.

92. Mélon, J., 1938, Acad. royale Belgique cl sci. Mem. (in- $8^{\circ}$ ), v. 17 , p. 31. Nil-Saint-Vincent, Belgium, Chlorite.

93. Lazarenko, E. K., 1950, Akad. Nauk SSSR Doklady, v. 72 , no. 4 , p. 772 , San-Donato, Urals, U.S.S.R. Corundophilite.

94. Agar, W. M., and Emendorfer, E. H., 1937, Am. Jour. Sci. ser. 5, v. 34, p. 79. Hawleyville, Conn. Prochlorite.

95. Serdyuchenko, D. P., 1953, Chlorites, their chemical constitution and classification, Izdel. Akad. Nauk SSSR, Moscow, p. 163, Table 54, no. 4. Northern Urals, U.S.S.R. Chlorite.

96. Ivanova, V. P., 1949, Akad. Nauk SSSR Geol. Inst. Trudy, v. 120, p. 69, Location not given. Ripidolite.

97. Ivanova, V. P., 1949, Akad. Nauk SSSR Geol. Inst. Trudy, v. 120, p. 69. Location not given. Ripidolite.

98. Phillips, W. R., 1954, Ph. D. Thesis, Univ. of Utah. Goscheneralp, Switzerland. Ripidolite.

99. Orcel, J., 1927, Soc. française Minéralogie Bull. 50, p. 360 , table 17, no. 100. Kasbek, Caucasus, Russia. Ripidolite.

100. Orcel, J., 1927, Soc. française Minéralogie Bull. 50, p. 252. Weilburg, Nassau, Germany. Aphrosiderite.

101. Frankel, J. J., 1944, Chemical, metallurgical and mining Soc., South Africa Jour., v. 44, p. 173. Witwatersrand, South Africa. Chlorite.

102. Korzhynskiy, A. F., 1959, Akad. Nauk SSSR, Sibirskoye Otdel. Vostochno-Sibirskiy Geol. Inst. Zapiski, p. 51, no. 1. Kholtason, Dzhidy, Russia. Ripidolite.

103. Orcel, J., 1927, Soc. française Minéralogie Bull. 50, p. 357, table 14, no. 81. Laifour, Ardennes, France. Ripidolite.

104. Ivanova, V. P., 1949, Akad. Nauk SSSR., Geol. Inst. Trudy, v. 120 , p. 69 . Location not given. Ripidolite.

105. Orcel, J., 1927, Soc. française Minéralogie Bull. 50, p. 238, table 14, no. 82. Presqu'ile Masoala, Madagascar. Ripidolite.

106. Hutton, C. O., 1938, Mineralog. Mag. v. 25, p. 198. Kawarau survey district, Western Otago, New Zealand. Chlorite.

107. Ross, C. S., 1935, U.S. Geological Survey Prof. Paper 179 , p. 66. Ore Knob, N. C. Chlorite.

108. Seitsaari, Juliani, 1954, Comm. Geol. Finlanda Bull., no. 166, p. 79. Kangasala, Finland. Chlorite.

109. Orcel, J., 1927, Soc. française Minéralogie Bull., v. 50, p. 358 , table 15 , no. 88 . Dragset, Norway. Ripidolite.

110. Orcel, J., 1927, Soc. française Minéralogie Bull., v. 50, p. 228. Androta, Madascar. Ripidolite.

111. Shirozu, H., 1958, Mineralog. Jour. Japan, v. 2, p. 212. Besshi mine, Ehimé Pref., Japan. Chlorite.

112. Ivanova, V. P., 1949, Akad. Nauk SSSR. Geol. Inst., Trudy, v. 120, p. 69. Location not given. Ripidolite.
113. Holzner, Julius, 1938, Neues Jahrb. Mineralogie, Geologie, u. Paläontologie, Beil-Band 73, Abt. A, p. 401, no. 1. Weilburg, Lahn-Dillgebiet, Germany. Aphrosiderite.

114. Orcel, J., 1927, Soc. française Minéralogie Bull., v. 50, p. 257. Evisa, Corsica. Thuringite.

115. Larsen, E. S., and Steiger, G., 1917, Washington Acad. Sci. Jour., v. 7, p. 10. Last Chance mine, Creede, Colo. Thuringite.

116. Serdynchenko, D. P., 1953, Chlorites, their chemical constitution and classification, Izdel. Akad. Nauk SSSR, Moscow, p. 163, table 54, No. 3. Northern Urals, Russia. Chlorite.

117. Ivanova, V. P., 1949, Akad. Nauk SSSR, Geol. Inst. Trudy, v. 120 , p. 65 . Location not given. Ripidolite.

118. Shirozu, H., 1958, Mineralog. Jour. Japan, v. 2, p. 212, no. 8. Osaruzawa mine, Akita Pref., Japan. Ripidolite.

\section{Brunsvigite}

119. Orcel, J., 1927, Soc. française Minéralogie Bull., v. 50, p. 231. La Croix, Isère, France. Ripidolite.

120. Hutton, C. O., 1938, Mineralog. Mag., v. 25, p. 198. Summitt of Coronet Peak, Wakatipu region, western Otago, New Zealand. Chlorite.

121. Harada, Z., 1959, Hokkaido Univ. Fac. Sci. Jour., ser. 4, v. 10 , p. 80 . Syōgaśe, Ino town, Agawa country, Kōti Pref., Japan. Chlorite.

122. Mélon, J., 1938, Acad. royale Belgique cl. sci., Mem. (in- ${ }^{\circ}$ ), v. 17, no. 4, p. 28. Lembecq, Belgium. Chlorite.

123. Bannister, F. A., and Whittard, W. F., 1945, Mineralog. Mag., v. 27, p. 102, no. 2. Wickwar, Gloucestershire, England. Magnesian chamosite.

124. Macgregor, A. M., 1941, Mineralog. Mag. v. 26, p. 103. Old West mine, Penhalonga, Southern Rhodesia. Chlorite.

125. Fromme, J., 1903, Tschermaks mineralog. petrog. Mitt., v. 22, p. 62. Radauthal, Harz, Germany. Pyknochlorite.

126. Kosik, S., 1930, Acad. Polonaise Sci., Lettres, cl. sci. math, nat. Bull., ser. A, p. 540. Slawkowska valley, West Tatra mountains. Delessite.

127. Serdyuchenko, D. P., 1953, Chlorites, their chemical constitution and classification, Izdel. Akad. Nauk SSSR, Moscow, p. 34, table 5. Mozikei river, Russia. Chlorite.

128. Kosik, S., 1930, Acad. Polonaise Sci., Lettres, cl. sci. math, nat. Bull., ser. A, p. 538. Wolowiec, West Tatra Mountains. Chlorite.

129. Holzner, J., 1938, Neues Jahrb. Mineralogie, Geologie, u. Paläontologie, Beil.-Band 73, Abt. A, p. 405. Ernsthausen, Lahn-Dillgebiet, Germany. Aphrosiderite.

130. Shannon, E. V., 1920, U. S. Natl. Mus. Proc. v. 57, p. 399, Westfield, Mass. Diabantite.

131. Ivanova, V. P., 1949, Akad. Nauk SSSR Geol. Inst. Trudy, v. 120, p. 72. Location not given. Aphrosiderite.

132. Fromme, J., 1902, Tschermaks mineralog. petrog. Mitt., v. 21 , p. 171. Radauthal, Harz, Germany. Brunsvigite.

\section{Diabantite}

133. Tomkeieff, S. I., 1943, Irish Naturalists Jour. v. 8, p. 71. Doon Point, Murlough Bay, Ireland. Diabantite.

134. Ross, C. S., and Shannon, E. V., 1924, U. S. Natl. Mus. Proc., v. 64, p. 15. Challis, Custer County, Idaho. Chlorite. 


\section{Thuringite}

135. Hödl, A., 1941, Neues Jahrb. Mineralogie, Geologie, u. Paläontologie, Beil.-Band 77, Abt. A, p. 28. Goldzeche, Rauriser Sonnblickgebiet, Carinthia, Austria. Thuringite.

136. Jung, H., and Köhler, E., 1930, Chemie der Erde, v. 5, p. 186. Schmiedefeld, Thuringia, Germany. Thuringite.

137. Simpson, E. S., 1937, Royal Soc. Western Australia Jour., v. 23, p. 21. Mount Satirist, Northwest division, Australia. Aphrosiderite.

138. Hödl, A., 1941, Neues Jahrb. Mineralogie, Geologie, u. Paläontologie, Beil.-Band 77, Abt. A., p. 27. Zirmsee, Rauriser Sonnblickgebiet, Carinthia. Thuringite.

139. Orcel, J., 1923, Acad. Sci. (Paris) Comptes rendus, v. 177, p. 272. Bas Vallon, near Quintin, Brittany, France. Thuringite.

140. Ivanova, V. P., 1949, Akad. Nauk SSSR. Geol. Inst. Trudy, v. 120 , p. 72 . Location not given. Thuringite.

141. Holzner, J., 1938, Neues Jahrb. Mineralogie, Geologie, u. Paläontologie, Beil.-Band 73, Abt. A, p. 403, no. 3. Fortuna, Lahn-Dillgebiet, Germany. Thuringite.

142. Ontoev, D. O., 1956, Akad. Nauk SSSR Izv., ser. geol., no. 4, p. 46, no. 2. Ostrogorskaya, U.S.S.R. Thuringite.

143. Zalinsky, E. R., 1904, Neues Jahrb. Mineralogie, Geologie, u. Paläontologie, Beil.-Band 19, p. 71. Schmiedefeld, Thuringia, Germany. Thuringite.

144. Déverin, Louis, 1945, Mater. Geol. Suisse, Ser. Geotechn, v. 2, no. 13, p. 89. Windgälle, Maderanerthal, Uri, Switzerland. Chamosite.
145. Shiroza, H., 1958, Mineralog. Jour. Japan, v. 2, p. 212, no. 11. Kishu mine, Mié Pref., Japan. Thuringite.

146. Kurnakov, N. S., and Chernykh, V. V., 1926, Mineralog, Obshch. Zapiski, v. 55, Pt. 1, p. 187, no. 13. Schmiedefeld, eastern Thuringia, Germany. Thuringite.

147. Simpson, E. S., 1936, Royal Soc. Western Australia Jour., v. 22, p. 3. Randalls, Central Division, Western Australia. Daphnite.

148. Slav́ik, F., and Veselý, V., 1923, Národního Musea Casopis, v. 97, p. 136. Ouvaly, east of Prague, Czechoslovakia. Aphrosiderite.

149. Simpson, E. S., 1936, Royal Soc. Western Australia Jour., v. 23, p. 22. Kalgoorlie, Western Australia. Daphnite.

150. Hallimond, A. F., 1939, Mineralog. Mag. v. 25, p. 443. Tolgus mine, Cornwall, England. Daphnite.

151. Phillips, W. R., 1954, Ph. D. Thesis, Univ. of Utah. Dona Ana County, N. Mex. Thuringite.

\section{Chamosite}

152. Ivanova, V. P., 1949, Akad. Nauk SSSR Geol. Inst. Trudy, v. 120, p. 72. Location not given. Thuringite.

153. Jung, H., 1931, Chemie der Erde, v. 6, p. 281. Schmiedefeld, Thuringia, Germany. Chamosite.

\section{Not named}

154. Ivanova, V. P., 1949, Akad. Nauk SSSR Geol. Inst. Trudy, v. 120 , p. 72 . Location not given. Thuringite. 